University of Rhode Island

DigitalCommons@URI

Open Access Master's Theses

1970

\title{
The Influence of 1, 3-Butylene Glucol and Fatty Acid Esters on Rat Reproduction and Development
}

\author{
Patricia King Adams \\ University of Rhode Island
}

Follow this and additional works at: https://digitalcommons.uri.edu/theses

\section{Recommended Citation}

Adams, Patricia King, "The Influence of 1, 3-Butylene Glucol and Fatty Acid Esters on Rat Reproduction and Development" (1970). Open Access Master's Theses. Paper 834.

https://digitalcommons.uri.edu/theses/834

This Thesis is brought to you for free and open access by DigitalCommons@URI. It has been accepted for inclusion in Open Access Master's Theses by an authorized administrator of DigitalCommons@URI. For more information, please contact digitalcommons-group@uri.edu. 
THE INFLUENCE OF 1,3-BUT YLENE GLYCOL AND FATTY ACID

ESTERS ON RAT REPRODUCTION AND DEVELOPMENT

BY

PATRICLA KING ADAMS

A THESIS SUBMITTED IN PARTIAL FULFILLMENT OF THE REQUIREMENTS FOR THE DEGREE OF

MASTER OF SCIENCE

IN

FOOD AND NUTRITIONAL SCIENCE

UNIVERSITY OF RHODE ISLAND

1970 
MASTER OF SCIENCE THESIS

OF

PATRICIA KING ADAMS

Approved:

Thesis Committee:

Chairman
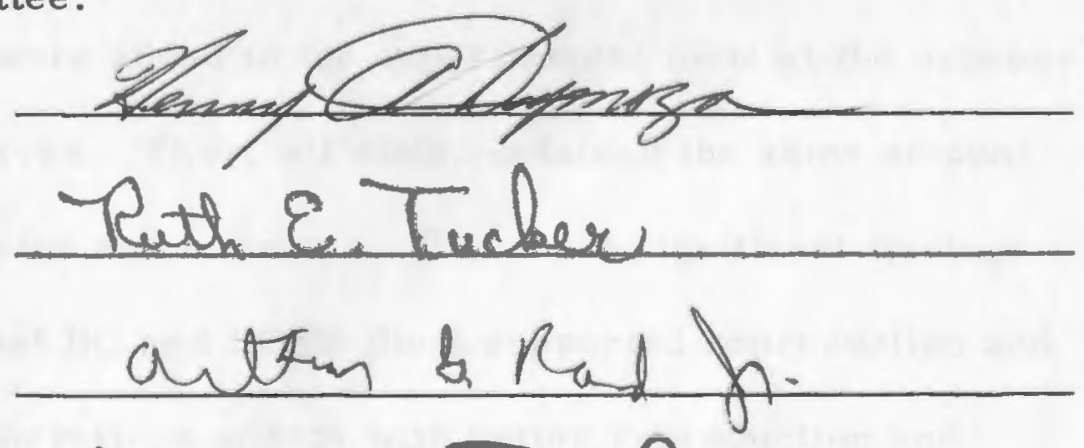

Oillim. R. Finar

Dean of the Graduate School

UNIVERSITY OF RHODE ISLAND 


\section{ABSTRACT}

The purpose of this study was to investigate the safety for human dietary consumption of three synthetic compounds which are potential sources of dietary energy, namely 1,3-Butylene Glycol (BG), 1,3-Butylene Glycol Mono-Oleate (BGMO) and 1,3-Butylene Glycol Mono-Stearate (BGMS), by feeding these compounds to parents and three generations of rats. Previous animal feeding studies had indicated that $B G$ was low in toxicity, but the effects of BG on reproduction had not been adequately established. No relative studies were known of the physiological and toxicological effects of the BGMO and BGMS compounds. Control and test diets were composed of semi-purified ingredients, with the only difference being that $20 \%$ of the test compounds were added to the experimental diets at the expense of carbohydrate sources. Thus, all diets contained the same amount of casein, fat, vitamins and minerals. The most significant findings of this study were that BG and BGMS diets supported reproduction and lactation in three generations of rats with better reproduction and lactation performances than rats fed the control or the BGMO diets. Food consumption and weight gains were generally higher for animals fed the control diet which furnished the least amount of calories. 
The fact that food efficiencies were essentially the same for all diets indicated that the test compounds were well utilized. All diets resulted in a low incidence of mortality and few pathological lesions, although more of both occurred in the BGMS group. The blood serum clinical tests and the histopathological evaluation of tissues essentially revealed no evidence that the compounds were toxic, except for some increase of lipid accumulation in liver tissues of males fed BGMS which may be of importance and could be further investigated. 


\section{ACKNOWLEDGEMENTS}

The author wishes to sincerely thank Dr. Henry A. Dymsza for his guidance and encouragement during the course of the research and for his assistance in the preparation of the manuscript. Grateful appreciation is also extended to Dr. Arthur G. Rand, Jr. and Dr. Ruth E. Tucker for their helpful suggestions and constructive criticisms.

The author also wishes to thank Dr. Edward J. Carney and Mr. Abel B. D'Silva for their advice and assistance with the statistical analyses of the data and for the use of the facilities at the University of Rhode Island Computer Laboratory.

Acknowledgement is due to Mr. Penchala Reddi for assistance with the care and necropsies of the animals.

Finally, the author wishes to express her appreciation to Mr. Norman Baker of the Celanese Corporation for supplying the 1,3-Butylene Glycol and financing the clinical analyses and the his topathology. 
TABLE OF CONTENTS

CHAPTER

PAGE

I.

INTRODUCTION $\ldots \ldots \ldots \ldots \ldots \ldots \ldots \ldots \ldots$

1

II. REVIE W OF THE LITERATURE $\ldots \ldots \ldots \ldots$

Occurrence in Nature $\ldots \ldots \ldots \ldots \ldots \ldots \ldots \ldots$

Acute Oral Toxicity ............... 5

Chronic Toxicity $\ldots \ldots \ldots \ldots \ldots \ldots \ldots \ldots$

Dermal and Mucous Membrane Toxicity ...... 6

Animal Feeding Studies............... 6

Metabolism ..................... 10

Physiological, Neuropharmacological

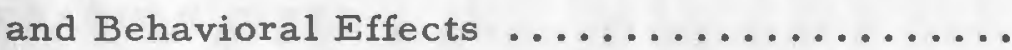

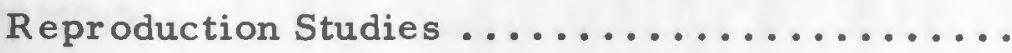

III. MATERIALS AND METHODS.............. 14

Animals and General Care ............ 14

Diets and Feeding $\ldots \ldots \ldots \ldots \ldots \ldots \ldots \ldots, 14$

Breeding and the Development of the Young .... 17

Necropsy and Terminal Studies.......... 19

Histopathology and Clinical Chemistry ..... 19

Statistical Analyses ................. 20 
IV. RESULTS AND DISCUSSION .............. 22

Fertility and Survival of Young ......... 22

Litter size, Birth and Weaning Weights...... 27

Food Consumption and Growth of Young

Litters ...................... 30

Adult Weight Gains and Terminal Body

Weights....................... 33

Terminal Organ Weights............. 43

Gross Pathology and Histopathology....... 56

Mortality ..................... 58

Clinical Chemistry................ 58

Hematology $\ldots \ldots \ldots \ldots \ldots \ldots \ldots \ldots \ldots \ldots .68$

v. SUMMARY AND CONCLUSIONS ........... 70

VI. LITERATURE CITED ................ 76

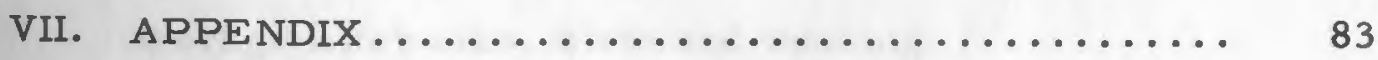


1. Composition of the experimental diets ........... 15

2. Experimental design showing number of generations reared $\ldots \ldots \ldots \ldots \ldots \ldots \ldots \ldots \ldots \ldots \ldots$

3. Number of females bred, litters produced and calculated fertility index $\ldots \ldots \ldots \ldots \ldots \ldots \ldots \ldots \ldots$

4. Number of rat pups born alive, successfully weaned and calculated survival index for each experimental generation of young animals.........

5. Effect of feeding the experimental diets on average litter size, birth and weaning weights within each generation $\ldots \ldots \ldots \ldots \ldots \ldots \ldots \ldots \ldots$

6. Effect of feeding each experimental diet on average litter size, birth and weaning weights for 3 gene rations $\ldots \ldots \ldots \ldots \ldots \ldots \ldots \ldots$

7. Average weight gain, food consumption and food efficiency for each generation of young animals fed experimental diets from 4 to 8 weeks of age.....

8. Effect of 4-week feeding of each experimental diet on average weight gain, food consumption and food efficiency of young animals for 3 generations. 
9. Average weight gain for each generation of male rats fed the experimental diets from

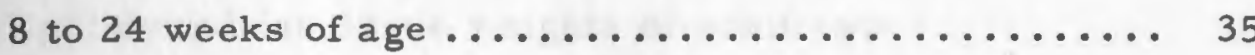

10. Effect of 16-week feeding of each experimental diet on average weight gain of male

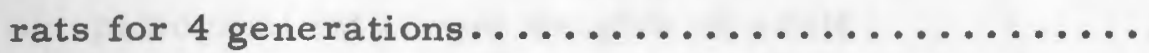

11. Terminal adult rat body weights at 24 weeks of age within each generation

12. Effect of feeding each experimental diet on terminal adult body weights for 4 generations........

13. Liver weights of adult rats fed experimental diets by generation $\ldots \ldots \ldots \ldots \ldots \ldots \ldots \ldots \ldots \ldots$

14. Effect of feeding each experimental diet on liver weights of adult rats for 4 generations ....... 46

15. Weights of kidneys of adult rats fed

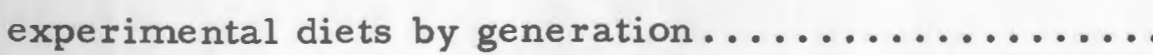

16. Effect of feeding each experimental diet on weights of kidneys of adult rats for 4 generations .....

17. Spleen weights of adult rats fed experimental diets by generation $\ldots \ldots \ldots \ldots \ldots \ldots \ldots \ldots \ldots$

18. Effect of feeding each experimental diet on spleen weights of adult rats for 4 generations........ 
19. Weights of testes of adult $\mathrm{F}_{2}$ generation male rats fed experimental diets ............. 52

20. Epididymal fat tissue weights of adult rats fed experimental diets by generation........... 53

21. Effect of feeding each experimental diet on epididymal fat tissue weights of adult male rats for 4 generations ................. 55

22. Clinical chemistry indices of the blood serum of adult $\mathrm{F}_{2}$ animals................. 59

23. Hematologic indices of a dult $\mathrm{F}_{3}$ animals ......... 69 


\section{LIS T OF FIGURES}

FIGURE

PAGE

1. Average weight gain of $\mathrm{F}_{2}$ male rats fed

the experimental diets from 8 to 24 weeks

of age $\ldots \ldots \ldots \ldots \ldots \ldots \ldots \ldots \ldots \ldots \ldots \ldots \ldots \ldots \ldots \ldots \ldots \ldots$ 


\section{APPENDIX}

PAGE

1. Properties of 1,3 -Butylene Glycol ............ 84

2. FDA approvals for the use of 1,3-Butylene

Glycol $\ldots \ldots \ldots \ldots \ldots \ldots \ldots \ldots \ldots \ldots \ldots \ldots \ldots$

3. Analytical data on 1,3-Butylene Glycol ester

samples $\ldots \ldots \ldots \ldots \ldots \ldots \ldots \ldots \ldots \ldots \ldots \ldots \ldots$

4. Composition of vitamin mix and amounts of

vitamins supplied per $\mathrm{kg} /$ diet $\ldots \ldots \ldots \ldots \ldots \ldots \ldots$

5. Report of the histopathologic evaluation of

tissues

6. Methodology used for clinical chemistry ........

7. Normal clinical values for the serum of rats

based on a study of Charles River animals........

8. Computer analysis of variance program ........ 100

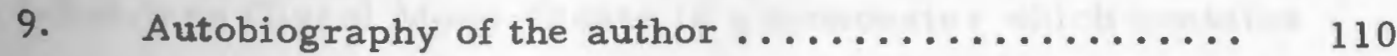




\section{INTRODUCTION}

There is a growing interest in synthetic sources of food which can contribute energy or calories to the diet and improve the quality of food products. This is important to a world faced with a mounting food shortage and caloric deficiencies. One promising synthetic compound is 1,3-Butylene Glycol (BG), a material with many unusual biological and nutritional characteristics which may be utilized in the improvement of existing foods or in the development of new food products.

Two derivatives, 1,3-Butylene Glycol Mono-Oleate (BGMO) and 1,3-Butylene Glycol Mono-Stearate (BGMS), are of interest because of their potential use as emulsifiers or as energy sources. The effects of these two derivatives in the body are of interest because they differ in degree of saturation. 1, 3-Butylene Glycol Mono-Oleate is a monoester which contains the monounsaturated fatty acid, oleic acid, whereas 1,3-Butylene Glycol Mono-Stearate is a monoester which contains the saturated fatty acid, stearic acid.

All three synthetic materials may be classified as high energy compounds since they yield considerable more metabolizable 
energy than carbohydrate. In 1967, Dymsza et al (17) and Miller and Dymsza (39) reported that the available metabolizable energy of these compounds was estimated in bioassay procedures using lard as a standard to be as follows: Lard, $9.0 \mathrm{kcal} / \mathrm{gm} ; \mathrm{BG}, 6.0 \mathrm{kcal} / \mathrm{gm}$; BGMO, $9.0 \mathrm{kcal} / \mathrm{gm}$; and BGMS, $7.6 \mathrm{kcal} / \mathrm{gm}$. These high energy compounds also have been suggested for use in military and space feeding where limitations must be placed on food weight and volume. The 1,3-Butylene Glycol produced synthetically by the Celanese Corporation from acetaldehyde by aldol condensation is a colorless, odorless material of high purity (99\%) (Table 1 , Appendix). At present food use is limited, as approval has been granted by the Federal Food and Drug Administration only for the use of 1,3-Butylene Glycol as a direct food additive in the form of a solvent for food flavors (Table 2, Appendix). Table 2 also lists a number of approvals for 1,3-Butylene Glycol as an indirect food additive in food packaging materials.

The two synthetic esters, BGMO and BGMS, obtained from the Wilson-Martin Division of Wilson and Company have not yet been approved for use as either direct or indirect food additives. The physical properties of these compounds are given in the Appendix in Table 3.

In exploring any new potential sources of food supply or additives to improve food products it is necessary to thoroughly 
evaluate the safety and value of these materials for human consumption. A reproduction study was chosen because very little research has been conducted on the reproductive performance of animals fed 1,3-Butylene Glycol. In addition, no research has been reported on the functioning of the reproductive processes when animals have been fed fatty acid derivatives of 1,3-Butylene Glycol. The object of this study was to investigate the safety and utilization of 1,3-Butylene Glycol (BG) and the two ester derivatives 1,3-Butylene Glycol Mono-Oleate (BGMO) and 1,3-Butylene Glycol Mono-Stearate (BGMS) as synthetic sources of dietary energy. The study was designed to determine the influence of diets containing a $20 \%$ level of either BG, BGMO, or BGMS as compared with a control diet on the fertility and development of a parent generation and three succeeding generations of rats. Pregnancy, lactation and the sensitive pre-weaning period of the young, are considered to be periods of great common or natural stress and provide excellent conditions in which to evaluate the safety of any new potential food. 


\section{REVIEW OF THE LITERATURE}

Considerable research on the various isomers of Butylene Glycol has been reported during the past twenty years by research workers in the United States and in other countries.

\section{Occurrence in Nature}

It has long been known that Butylene Glycols are products of alcoholic and lactose fermentation. In 1948 Genevois et al. $(23,24)$ reported the presence of Butylene Glycols in secondary products of the alcoholic fermentation of elliptic yeasts and Bordeaux red wines. Gobis and Pisek (27) in 1950 also found Butylene Glycols in aged cream and most Italian cheeses. Patschky (43) in 1967 indicated that in alcoholic fermentation products, the most prevalent Butylene Glycol isomer is 2,3-Butylene Glycol which is considerably more toxic than the 1, 3 isomer, an observation made by Fischer et al. (21) in 1949. A recent publication by Dube (14) in 1968 disclosed the presence of Butylene Glycols in bovine rumen fluids.

Since 1964 the Russian researchers, Bergelson et al. (2-4) and Vaver et al. $(57,58)$ have published reports which are interesting and may prove to be of scientific significance. These workers found 1,3-Butylene Glycol and other diols in the neutral fraction of corn 
oil, sunflower oil, sheep fat, cod liver oil, soil yeast, and rat liver and heart tissue. Their studies did not yield any free diols indicating that the polyhydric alcohols were in ester form with palmitic, oleic, linoleic and stearic acid. It was proposed by Bergels on and Vaver (4) in 1966 that the diol lipids may be involved in cell membrane action.

\section{Acute Oral Toxicity}

Reports on the low acute oral toxicity of 1,3-Butylene Glycol first appeared in the literature in 1949 with the publications by Fischer et al. (21) and Loeser (33), and later in 1951 by Smyth et al. (51). Single dose oral $\mathrm{LD}_{50}$ values for rats were reported in these publications as ranging from 22.8 to $29.4 \mathrm{gm} / \mathrm{kg}$ while those reported for mice were $23.3 \mathrm{gm} / \mathrm{kg}$. Subsequent studies by Bornmann (9, 10) in 1954 and in 1955 (11) also showed that 1,3-Butylene Glycol was of low toxicity when given to rats and mice. While the purity of the 1,3-Butylene Glycol used in the tests was not stated, the results, however, indicated the low acute oral toxicity of this compound.

\section{Chronic Toxicity}

Chronic toxicity studies reported by Dyms za and Stoewsand $(15,16)$ in 1965 and 1966, and by Scala and Paynter (47) in 1967 have provided evidence of low toxicity and good utilization of 1,3-Butylene 
Glycol. Rats receiving a 10\% dietary level of 1,3-Butylene Glycol for two years (47) and a $20 \%$ dietary level of 1,3-Butylene Glycol for 476 days (15) developed no ill effects as evaluated by histopathology. At the $20 \%$ level of feeding, due to a decrease in food consumption, body weight gains of the rats were lower than those of non-1,3-Butylene Glycol controls. In the dog tests, two years of feeding a $3 \%$ dietary level of 1,3-Butylene Glycol (47) and 343 days of feeding a $20 \%$ dietary level of 1,3-Butylene Glycol (16) resulted in no gross or histopathologic changes of significance.

Dermal and Mucous Membrane Toxicity

Reports by Fischer et al. (21) and Loeser (33) in 1949 , and Husing et al. (29) in 1950, all indicated that 1,3-Butylene Glycol causes no significant ir ritations to the skin and oral membranes of the mouth in animals and humans or to the mucous membranes of the eye and large intestines of experimental animals. In one phase of the study conducted by Fischer and co-workers (21), use of a toothpaste containing 1,3-Butylene Glycol for four weeks produced no signs of irritation to the mucous membranes of the mouth of human subjects.

Animal Feeding Studies

Use of polyhydric alcohols as a possible new source of dietary energy was first proposed by Schlüssel $(49,50)$ in 1953. 
When seven polyols were tested by feeding to rats at levels of 5 to $40 \%$ of dietary calories it was found that 1,3-Butylene Glycol was the best tolerated. In these studies, 1,3-Butylene Glycol fed at levels up to $40 \%$ of the total calories was well tolerated by female rats during an eight-week feeding period with a resulting increase in food intake and body weight.

In the utilization study reported by Miller and Dymsza (39) in 1967, levels of $20 \%$ and $30 \% 1,3$-Butylene Glycol on a dry weight basis of the diet were incorporated into high fat $(30 \%)$ diets and fed to rats for 30 weeks. Good utilization resulted after a one-week adaptation period, providing the level of feeding did not exceed $20 \%$ of the diet. Utilization, as indicated by reduced growth and nutrient efficiency, was impaired by diets containing 30\% 1,3-Butylene Glycol. Other observations noted were that the rats fed the glycol diets generally had increased liver phosphohexose isomerase and liver glycogen, while serum glucose and serum and urinary ketone bodies were not affected. The lack of ketonemia and ketouria appeared to indicate that 1,3-Butylene Glycol is not oxidized via B-hydroxybutyric acid.

\section{Davenport et al. (13) in 1967 found that day-old chicks} may not be able to utilize as high levels of 1,3-Butylene Glycol as rats and dogs and may require longer periods of adaptation. They observed that chicks were able to utilize most efficiently a level of 
5\% 1,3-Butylene Glycol in their diet. Above this level, probably due in part to unpalatibility, feed consumption and growth declined progressively as 1,3-Butylene Glycol was increased in the diet.

In a cold stress study reported by Stoewsand et al.

in 1965 , it was shown that male rats receiving a $20 \%$ dietary level of 1,3-Butylene Glycol plus 30\% fat in their diets had a decrease in epididymal adipose tissue weight and epididymal lipid content. Since this measurement was used as an indicator of total body fatness, 1,3-Butylene Glycol fed rats were presumably leaner than the controls. This may have accounted for their reduced resistance when exposed to cold temperatures of $5^{\circ} \mathrm{C}$ or $-10^{\circ} \mathrm{C}$ for periods of one to two weeks. An increase in total liver lipids, not exceeding $8.1 \%$ was also noted.

Similar results were obtained by Stoewsand and co-workers (54) in 1966 in another experiment in which rats were fed dietary levels of 20\% 1,3-Butylene Glycol, propylene glycol and glycerol, and maintained for four weeks either at $25^{\circ} \mathrm{C}$ or $5^{\circ} \mathrm{C}$. At both temperatures, rats receiving 1,3-Butylene Glycol or propylene glycol had lower body weight gains and reduced epididymal adipose tissue weights than the controls or the glycerol fed rats. The same animals also had decreased resistance when exposed to a cold temperature of $-20^{\circ} \mathrm{C}$. However, the food and calorie efficiencies of the rats consuming any of the three polyhydric alcohols were 
similar to the efficiencies of rats fed a $30 \%$ fat control diet when maintained at $25^{\circ} \mathrm{C}$ or $5^{\circ} \mathrm{C}$.

In 1966 Mehlman et al. (34) investigated the distribution of lipids in rats fed 1,3-Butylene Glycol. The addition of $20 \%$ 1,3-Butylene Glycol to diets containing either 10 or $30 \%$ fat resulted in a slight increase in total liver lipids, specifically triglycerides and cholesterol esters. This is in agreement with the findings of Stoewsand et al. (53). Other observations reported by Mehlman and co-workers showed that blood plasma levels of non-esterified fatty acids (free fatty acids or FFA), triglycerides and cholesterol esters were higher in animals receiving 1,3-Butylene Glycol. However, the free cholesterol content of the plasma was not affected by the presence of glycol in the diet. They speculated that the higher levels of FFA in the plasma of rats fed 1,3-Butylene Glycol may indicate a high state of mobilization of lipid from adipose tissue. This may be related to the fact that animals fed 1,3-Butylene Glycol had smaller epididymal fat pads (34). Also, the higher plasma triglyceride levels in rats fed 1,3-Butylene Glycol may indicate that the re was no impairment in the ability to transport low density lipoprotein from liver to plasma.

The conclusions drawn from these studies have indicated a need for further investigation of changes in tissue lipids of animals fed 1, 3-Butylene Glycol $(34,53,54)$. 
Metabolism

Elucidation of the metabolic pathway and fate of 1,3-Butylene Glycol in higher animals is not possible at this time because of a lack of clear-cut evidence. In 1958 Opitz $(40,41)$ reported in two papers that neither glucose nor glycogen was synthesized in rat liver slices incubated with 1,3-Butylene Glycol. He also reported that administration of 1,3-Butylene Glycol to rats did not increase the glycogen content of their livers. The fate of oral doses of 22 glycols in rabbits was investigated by Gessner et al. (25) in 1960. No metabolic product of 1,3-Butylene Glycol was isolated, but it was postulated that it should be metabolized to B-hydroxybutyric acid. In 1963 , Kersters and de Ley (31) reported that the end product of the oxidation of DL-1,3-Butylene Glycol by acetic acid bacteria was DL-B-hydroxybutyric acid. Schubert and Kexel (48) in 1964 found a butanediol dehydrogenase reaction in some Pseudomonadaceae bacteria. However, in work reported in 1966, Ferguson et al. (20) found that various human and rat endocrine tissues did not contain alcohol dehyrogenases capable of reacting with 1,3-Butylene Glycol. Miller and Dymsza (39) in 1967 showed that feeding large amounts of 1,3-Butylene Glycol to rats did not produce an increase in serum or urinary ketone body levels, but did result in small increases in liver glycogen. The metabolism in vivo of 1,3-Butylene Glycol-1 $-{ }^{14} \mathrm{C}$ in the rat was studied by Miller et al. (38) in 
1965. They found that approximately $60 \%$ of orally ingested activity was oxidized to $\mathrm{CO}_{2}$ in 12 hours and $90 \%$ in 48 hours. The time required to metabolize labeled 1,3-Butylene Glycol to ${ }^{14} \mathrm{CO}_{2}$ was shorter than that reported for some long chain orally administered fatty acids. Since urinary excretion levels of labeled 1,3-Butylene Glycol derived activity were rather low, ketone bodies were not the principal products of metabolism. The 1,3-Butylene Glycol was termed "glycogenic" because the activity in liver glycogen was of the same order of magnitude as that of rats fed labeled propionate.

Physiological, Neuropharmacological and Behavioral Effects

As early as 1953, Bornmann and Ritter (8) found that 1,3-Butylene Glycol and other polyhydric alcohols had a diuretic action when given orally or intramuscularly to rats. However, in 1954 and 1955 Bornmann (9-11) reported that the diuretic effects of 1,3-Butylene Glycol and glycerol were less than that of ethylene glycol or diethylene glycol.

Another important physiological characteristic noted by Bornmann $(7,9-11)$ was the absence of any secretion of hemoglobin in the urine when 1,3-Butylene Glycol was injected subcutaneously.

An example of the unusual pharmacological properties of the compound is Mehlman's (35) finding in 1967 that 1, 3-Butylene Glycol has a possible protective effect on rats with experimental alloxan diabetes. Further investigation of the effect of 1,3-Butylene 
Glycol on experimental alloxan diabetes in rats is being conducted in the Department of Pharmacology at the University of Rhode Island.

In 1949, it was recognized by Fischer et al. (21) that all glycols, including 1,3-Butylene Glycol, have a narcotic effect when administered in sufficiently large doses. Stoewsand et al. in 1966 (55) reported that dogs experienced marked muscular incoordination for a few hours after consuming a 30\% level of 1,3-Butylene Glycol in a one-meal diet. Further investigations by these workers showed an occurrence of a depression of the central nervous system as indicated by electroencephalograms after an intravenous infusion of $6 \mathrm{ml} / \mathrm{kg}$ in dogs (56). Experimenting with rats, Sprince and co-workers (52) in 1966 found that $4 \mathrm{gm} / \mathrm{kg}$ administered intraperitonealy depressed motor activity while $7 \mathrm{gm} / \mathrm{kg}$ had a marked anesthetic effect. In 1968, Is grig and Ayres (30) confirmed the sedative effect but also noted that equal doses of 1,3-Butylene Glycol did not have as marked an effect on equilibrium as ethyl alcohol.

\section{Reproduction Studies}

There have been only two reported studies in the literature on the effect of 1,3-Butylene Glycol on the reproductive processes. In the first study by Meyer (36) in 1951, long-term administration to rats of one $\mathrm{ml}$ of a $50 \%$ aqueous solution of 1,3-Butylene Glycol per $\mathrm{kg}$ of body weight at intervals of three to four days was without ill 
effect on parents and the first and second generation of rats. In the second study by Meyer and Shurmeyer (37) in 1951, feeding rats one $\mathrm{ml}$ of a $50 \%$ aqueous solution of 1,3-Butylene Glycol twice weekly for six months and continuing throughout pregnancy and the suckling period produced no abnormality in fertility or in the development of the following three generations.

Reasons for the experimental design and the low doses administered in these early studies are difficult to clearly interpret. In the reproduction study to be described, much higher levels of 1,3-Butylene Glycol and esters were administered, approximately seventy times greater than those in the above studies. 


\section{MATERIALS AND METHODS}

\section{Animals and General Care}

Eight-week-old Sprague-Dawley derived (Charles River Breeding Laboratory) rats were obtained for breeding purposes to initiate the experiment. The animals were randomly divided into four groups, each group consisting of seven females and two males. The control diet was fed to the animals in group one, and the experimental diets containing either BG, BGMO, or BGMS were fed to groups two, three, and four, respectively. Ear punches were made to distinguish the treatment groups.

The animals were housed in metal cages with mesh bottoms in animal quarters where the temperature was maintained at $21-27^{\circ} \mathrm{C}$. The health and behavior of the animals were observed daily. Food consumption of each group, individual weights of the adult animals and weight gains of the young litters were determined weekly. These records were kept for each generation throughout the entire experiment which was conducted over a period of 15 months.

\section{Diets and Feeding}

The composition of the diets is presented in Table 1. 


\section{TABLE 1}

Composition of the experimental diets

\section{Diets}

\begin{tabular}{|c|c|c|c|}
\hline Control & $\mathrm{BG}^{1}$ & $\mathrm{BGMO}^{2}$ & BGMS $^{3}$ \\
\hline$\%$ & $\%$ & $\%$ & $\%$ \\
\hline
\end{tabular}

Ingredients

$\begin{array}{lrrrr}\text { Casein } & 22.0 & 22.0 & 22.0 & 22.0 \\ \text { Cornstarch } & 12.7 & 7.7 & 7.7 & 7.7 \\ \text { Dextrin } & 12.7 & 7.7 & 7.7 & 7.7 \\ \text { Glucose } & 12.7 & 7.7 & 7.7 & 7.7 \\ \text { Sucrose } & 12.7 & 7.7 & 7.7 & 7.7 \\ \text { Corn Oil } & 10.0 & 10.0 & 10.0 & 10.0 \\ \text { Lard } & 10.0 & 10.0 & 10.0 & 10.0 \\ \text { BG } & -- & 20.0 & -- & -- \\ \text { BGMO } & -- & -- & 20.0 & -- \\ \text { BGMS } & -- & -- & -- & 20.0 \\ \text { Cellulose } & 2.0 & 2.0 & 2.0 & 2.0 \\ \text { Mineral Mix } & 4.0 & 4.0 & 4.0 & 4.0 \\ \text { Vitamin Mix } & 1.2 & 1.2 & 1.2 & 1.2 \\ & & & & \\ \text { TOTAL } & 100.0 & 100.0 & 100.0 & 100.0\end{array}$

Metabolizable energy, calculated (kcal/kg)

1 1,3-Butylene Glycol.

2 1,3-Butylene Glycol Mono-Oleate.

3 1,3-Butylene Glycol Mono-Stearate.

4 Rogers-Har per salt mix (46).

5 Vitamin mix (Table 4, Appendix). 
Food and water were fed ad libitum. All of the diets contained $22 \%$ casein and $20 \%$ fat, one-half of which was corn oil and the other half was lard. In addition, all the diets contained $2 \%$ cellulose and 4\% Rogers-Harper salt mix (46). Carbohydrate was the variable ingredient. The control diet contained $50.8 \%$ carbohydrate while the three experimental diets were prepared by adding $20 \%$ of either $\mathrm{BG}, \mathrm{BGMO}$ or $\mathrm{BGMS}$ at the expense of the carbohydrate sources. However, the carbohydrate in all the diets was furnished by cornstarch, dextrin, glucose and sucrose in a 1:1:1:1 ratio. All the diets were iso-nitrogenous but not iso-caloric as the available metabolizable energy for each of the synthetic compounds was estimated by Miller and Dymsza (39) and Dymsza et al. (17) to be as follows: BG, $6.0 \mathrm{kcal} / \mathrm{g}$; BGMO, $9.0 \mathrm{kcal} / \mathrm{g}$; and BGMS, 7.6 $\mathrm{kcal} / \mathrm{g}$.

The diets were prepared weekly by thoroughly mixing all the ingredients in a 12 -quart batch mixer and stored in the refrigerator. It was found that it was not necessary to incorporate dissolved agar into the mixture to improve the consistency as the investigators, Miller and Dymsza (17) have done previously. Fresh food was measured into heavy feeding jars every two days. These jars were then placed into a second larger container to collect spillage. Some spillage, however, was unavoidable. 
Breeding and Development of the Young

Following a short adjustment period, the females were bred at 11 weeks of age to males on the same diet. The males, which were rotated every three days, were caged together with two females. When pregnancy was established by an approximate gain in weight, the females were then caged individually until the young were weaned at the age of 21 days.

Reproduction results were carefully recorded. All pups were examined within 24 hours after parturition for number of live born, number of still born, total live litter weight, and general health which included color, relative size, physical structure, and evidence of suckling. Litters were examined daily for number of live and dead young. At 21 days, each litter was counted, weighed, sexed and separated into group cages to be maintained together on their respective diets for the next five weeks.

At eight weeks of age, ten females and five males with similar weights were randomly selected from each group to be used as breeders for the next generation. All other young animals were discarded. The same procedure was repeated with the mating of each new generation until the $\mathrm{F}_{3}$ generations were obtained. Table 2 shows the experimental design, the number of generations reared and the symbols used for each generation. 
TABLE 2

Experimental design showing number of generations reared ${ }^{1}$

Generations

Symbol for generations

Parents

$$
\downarrow \text { 1st litter }
$$

First Generation

$$
\downarrow \text { 1st litter }
$$

Second Generation

$$
\downarrow^{\text {lst litter }} \text { 2nd litter }{ }^{2}
$$

Third Generation
$F_{0}$

$\mathrm{F}_{1}$

$F_{2}$

$F_{3(1)}$

$F_{3(2)}$

1 Same diets fed from $F_{0}$ to $F_{3}$ generations.

${ }^{2} \mathrm{~F}_{2}$ generation remated in an attempt to obtain more live $\mathrm{F}_{3}$ litters. 
Necropsy and Terminal Studies

All adult animals were decapitated at 24 weeks of age with the exception of the $F_{3}$ second litters which were sacrificed at 15 weeks in order to terminate the experiment. The blood was collected, refrigerated and centifuged. After clotting, the serum was removed and frozen.

Necropsies were performed on all animals for evidence of any gross pathology. The following organ weights were recorded: liver, spleen, kidneys, testes and fat pads. Each organ was carefully freed of fat and connective tissue, then gently blotted on paper to remove blood and immediately weighed. A portion of each organ together with samples of other abdominal and thoracic organs were preserved in $10 \%$ buffered neutral formalin for histopathological examination. The remaining portion of the livers was immediately frozen with liquid nitrogen and held for possible analyses.

All mortalities were recorded, and abnormal organs were preserved throughout the experiment.

\section{His topa thology and Clinical Chemistry}

Histopathological evaluation of the organ tissues from the $\mathrm{F}_{2}$ animals was completed by Dr. Paul M. Newberne, Professor of Nutritional Pathology at the Massachusetts Institute of Technology. Using the control group as a reference, frozen liver sections were stained with oil red-O to reveal lipid accumulations. In addition, 
tissues from the liver, spleen, heart, aorta, kidney and adrenal glands were embedded in paraffin, sectioned at 6 microns, stained with hematoxylin and eosin and examined microscopically for histopathologic alterations. Dr. Newberne's report is given in the Appendix on pages 88 to 93.

The serum of the $F_{2}$ animals was analyzed by the Charles River Laboratories in Brookline, Massachusetts, for biochemical tests as follows: cholesterol, calcium, inorganic phosphorus, bilirubin, total protein, albumin (A), globulin (G), A/G ratio, uric acid, urea nitrogen, glucose (true), lactic dehydrogenase (LDH), alkaline phosphatase, serum glutamic oxalacetic transaminase (SGOT) and triglycerides. The methodology used for these tests is described in the Appendix on pages 94 to 98.

Blood count differentials were determined from slides made from adult $F_{3(1)}$ animals. The hematocrit of the $F_{3(1)}$ animals was calculated from fresh blood collected into heparinized capillary tubes and centifuged.

Statistical Analyses

The data was statistically analyzed by the University of Rhode Island Computer Laboratory according to a two-way analys is of variance computer program. The program was initially obtained from the Massachusetts Institute of Technology and further modified by the Data Analysis Office of the U.S. Army Natick Laboratories, 
Natick, Massachusetts.

The output from the program is as follows:

(1) The experimental data listing the individual observations by groups.

(2) The group designation, the number of observations in that group, the mean, variance, standard deviation and standard error of the mean for that group.

(3) The analysis of variance table including the sum of squares, degrees of freedom, mean square and $F$ ratio. (4) The group difference table where the means of all the groups are compared with the least significant difference at the 0.05 level ( $95 \%$ confidence level).

A print-out copy of the computer program is included in the Appendix on pages 100 to 109. 


\section{RESULTS AND DISCUSSION}

The results presented are based on data obtained from maintaining separate groups of rats entirely on each of the four dietary regimes shown in Table 1. The diets were fed to a parent generation and three succeeding generations of animals. In order to have an orderly presentation of the data obtained for each generation, the results and discussion have been catergorized under several appropriate headings.

\section{Fertility and Survival of Young}

Table 3 shows the number of pregnancies and the fertility indices for all breedings of the four diet groups. In the parent generation, there was no obvious effect on fertility that could be attributed to either BG or BGMO, but the fertility index was slightly lower for the BGMS group (86\%) and was only $50 \%$ for the control group. The control group performed much better in the $F_{1}$ generation with a fertility index of $100 \%$, although one litter was born dead, as compared with indices of $80 \%$ for the BG group, $90 \%$ for the BGMO (one litter born dead) and $90 \%$ for the BGMS group. In the first mating of the $F_{2}$ generation, 


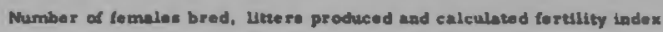

\begin{tabular}{|c|c|c|c|c|c|c|c|c|c|c|c|c|c|c|c|c|}
\hline \multirow[t]{2}{*}{ Ceneration } & \multirow[b]{2}{*}{$\begin{array}{c}\text { Temales } \\
\text { no. }\end{array}$} & \multicolumn{2}{|c|}{ Control } & \multicolumn{5}{|c|}{ 1, 3-Dutylene Clycel } & \multicolumn{4}{|c|}{ 1. 3-Butylone Clyeol Moro-Oleato } & \multicolumn{4}{|c|}{ 1, 3-Butylemes Olyeal Mono-stearate } \\
\hline & & $\begin{array}{l}\text { Literer. } \\
\text { produced } \\
\text { no. }\end{array}$ & $\begin{array}{l}\text { Litters } \\
\text { born allive } \\
\text { no. }\end{array}$ & $\begin{array}{c}\text { Forkllity' } \\
\text { index }\end{array}$ & $\begin{array}{c}\text { Temelos } \\
\text { no. }\end{array}$ & $\begin{array}{l}\text { Lineres } \\
\text { protuced } \\
\text { no. }\end{array}$ & $\begin{array}{l}\text { Litters } \\
\text { born alive } \\
\text { no. }\end{array}$ & $\begin{array}{c}\text { Torkility } \\
\text { indox }\end{array}$ & $\begin{array}{c}\text { Temales } \\
\text { no. }\end{array}$ & $\begin{array}{l}\text { Lituer } \\
\text { produced } \\
\text { no. }\end{array}$ & $\begin{array}{c}\text { Litter: } \\
\text { born alive } \\
\text { no. }\end{array}$ & $\begin{array}{c}\text { Tertally } \\
\text { tadex }\end{array}$ & $\begin{array}{c}\text { Tomalen } \\
\text { no. }\end{array}$ & $\begin{array}{l}\text { Litters } \\
\text { prodeced } \\
\text { no. }\end{array}$ & $\begin{array}{l}\text { Litherb } \\
\text { born alive } \\
\text { no. }\end{array}$ & $\begin{array}{c}\text { Tortlity } \\
\text { Indox }\end{array}$ \\
\hline$r_{0}$ (Parente) & 6 & 3 & 3 & so & 7 & 7 & ? & 100 & 7 & 8 & 7 & 100 & 7 & 6 & 6 & 86 \\
\hline$r_{1}$ & 10 & 10 & 9 & 100 & 10 & 8 & - & so & 10 & 9 & 8 & 90 & 10 & ? & ? & 90 \\
\hline $\mathbf{r}_{2}$ & 10 & - & 6 & 80 & 10 & 9 & ? & 90 & 10 & 9 & - & 90 & 9 & 8 & 7 & $\bullet$ \\
\hline TOTAL & 36 & 21 & is & & 37 & 28 & 28 & & 37 & 27 & 23 & & 33 & 30 & 29 & \\
\hline
\end{tabular}

${ }^{1}$ rortility index: porcentage of matinge resulting in litters produced.

TABLE 4

Number of rat pupg bora alive, succenofully waened and calculated survival index for oach experimental generation of young animale

\begin{tabular}{|c|c|c|c|c|c|c|c|c|c|c|c|c|}
\hline \multirow[t]{2}{*}{ Genoretion of young } & \multicolumn{3}{|c|}{ Control } & \multicolumn{3}{|c|}{ 1, J-Butylene Giycol } & \multicolumn{3}{|c|}{ 1. 3-Dutylene Glycol Mono-Oleate } & \multicolumn{3}{|c|}{ 1, 3-Eutrieno O1yeol Meno-Stesrate } \\
\hline & $\begin{array}{c}\text { Pups born } \\
\text { allve } \\
\text { no. }\end{array}$ & $\begin{array}{l}\text { Pups } \\
\text { weened } \\
\text { ao. }\end{array}$ & $\begin{array}{c}\text { survival } \\
\text { index }\end{array}$ & $\begin{array}{l}\text { Pape bors } \\
\text { alive } \\
\text { no. }\end{array}$ & $\begin{array}{l}\text { Pupe } \\
\text { weaned }\end{array}$ & $\begin{array}{c}\text { Survivei } \\
\text { index }\end{array}$ & $\begin{array}{l}\text { Pupe bern } \\
\text { elive } \\
\text { no. }\end{array}$ & $\begin{array}{l}\text { Pupa } \\
\text { weaned } \\
\text { no. }\end{array}$ & $\begin{array}{c}\text { Survival } \\
\text { index }\end{array}$ & $\begin{array}{l}\text { Pupa borm } \\
\text { altve } \\
\text { no. }\end{array}$ & $\begin{array}{l}\text { Pupe } \\
\text { wosned } \\
\text { no. }\end{array}$ & $\begin{array}{l}\text { Survival } \\
\text { index }\end{array}$ \\
\hline$r_{1}$ & 36 & 30 & 79 & 78 & 67 & 86 & 66 & 31 & 17 & 72 & 27 & 38 \\
\hline$r_{2}$ & 84 & 32 & 38 & 78 & 62 & 79 & $n$ & 31 & 44 & 85 & 72 & 85 \\
\hline$r_{3(1)}$ & 47 & 8 & 17 & 86 & 31 & 36 & 30 & -. & -. & 33 & 27 & 31 \\
\hline$r_{3(3)^{2}}$ & 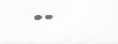 & $\cdots$ & $-\cdot$ & 35 & 16 & 46 & -- & -. & -. & 47 & 28 & 60 \\
\hline TOtAL & 169 & 70 & & 277 & 176 & & 195 & 62 & & 237 & 154 & \\
\hline
\end{tabular}

1 survival index: porcentage of pups born alive that aurvived to wouning at 21 daye. 
fertility indices were $80 \%, 90 \%, 90 \%$, and $89 \%$ for the control, $B G, B G M O$ and BGMS groups, respectively. However, the data obtained from the second mating of the $F_{2}$ generation was unexpected. None of the control females produced litters, while four of the BG females produced litters. Two of the BGMO females produced litters but both of litters were stillborn. It was remarkable that seven BGMS females had successful pregnancies.

No pregnancy failure could be attributed solely to a male as the rotation schedule of breeding always provided contact of each male with every female. Age could not have been a factor eithe $r$, as all animals were bred at 11 weeks of age, and the $F_{2}$ generation was approximately 17 weeks old when mated for the second time.

Survival indices, the percentage of pups born alive that survived to weaning at 21 days, for all three generations are shown in Table 4. In the $F_{1}$ generation (litters from $F_{0}$ parents), the survival index was good for both the control (79\%) and BG $(86 \%)$ groups but poor for the BGMO (47\%) and BGMS (38\%) groups. Entirely different results were obtained in the $F_{2}$ generation where the survival index dropped to $38 \%$ for the control group but rose to $79 \%$ and $85 \%$ for the BG and BGMS groups, respectively. The BGMO group remained consistently poor with a survival index 
of $44 \%$. Poor results were obtained in the $\mathrm{F}_{3(1)}$ generation as the survival rates declined in all groups. The control group decreased to $17 \%$ while the BG and BGMS groups declined to $36 \%$ and $51 \%$, and no pups survived in the $B G M O$ group. In the $F_{3(2)}$ generation, no litters were produced in the control or BGMO groups. However, the survival index for the $\mathrm{BG}$ group rose slightly to $46 \%$, and the index for the BGMS group rose to $60 \%$.

When all three generations of pups are considered, it is evident that the most pups born alive and the most pups that survived to weaning at 21 days were from the BG and BGMS groups. This was interesting as conditions of housing, feeding and handling were the same for all groups in all generations. Only one female died during the lactation period, a $B G\left(F_{2}\right)$ female with a bladder infection. If it had been possible to keep her healthy litter of nine pups alive, the total number of $B G$ pups that survived would have been fur ther increased.

In the breedings of three generations of four diet groups, larger fertility and survival indices were generally obtained for the $B G$ and BGMS groups. These results are difficult to explain. It is not known whether these two particular compounds contain any protective factors or whether they possibly possess estrogenic activity or exert an influence on steriod metabolism. Also it is difficult to account for the poor results in the control and BGMO groups. 
A possible clue may be found in the fact that other investigators, Pleasants et al. (45), have had difficulty in raising succeeding generations of rats on purified diets. Ershoff et al. (19) have also suggested that natural food stock rations contain a factor not present in highly purified diets that can protect mice from tumor development after $\mathrm{X}$-irradiation. However, in this present study, all four semi-purified diets, including the control diet, contained the same amount of casein, fat, vitamins and minerals. The report on the nutrient requirements of laboratory rats by Warner (59) indicated that the vitamin mixture contained sufficient amounts of vitamin A, vitamin E, niacin, panthothenic acid and pyridoxine, as deficiencies of these vitamins are known to cause reproductive and lactation failures. While the diets were not iso-caloric due to the substitution by weight of $20 \%$ of the synthetic compounds for carbohydrate in the experimental diets, the control diet which furnished the least amount of calories and the BGMO diet which furnished the most calories both produced poor results. It might be speculated that the mono-unsaturated fatty acid, oleic acid, which was present only in the BGMO diet may have contributed to the inferior results in this group. It would be interesting to observe in further experiments whether different results could be obtained by increasing the amount of vitamin $\mathrm{E}$ in this diet for anti-oxidant protection against lipid peroxidation. 
Litter Size, Birth and Weaning Weights

Average litter size, as shown in Table 5, was not affected by any of the dietary treatments until the $F_{3(2)}$ generation when no BGMO pups were born alive and no control litters were produced. Average birth weight of the pups was also not affected in the $F_{1}$ generation, but there were significant differences at the $(P<0.05)$ level in the $F_{2}$ and $F_{3(1)}$ generations. In both of these generations, the control group had the highest average birth weight while there were only a few significant differences between the other three groups. The $F_{3(2)}$ generation provided a poor comparison as only the BG and BGMS litters survived, and there were no significant birth weight differences between them. The dietary treatments apparently had no effect on average weaning weights in the $F_{1}, F_{3(1)}$ and $F_{3(2)}$ generations of surviving pups. There were significant differences in the $\mathrm{F}_{2}$ generation in that the control group had the highest average weaning weight, and the BGMS had the lowest average weaning weight.

Table 6 shows the litter size, birth weights and weaning weights of rats fed the control or experimental diets for three succeeding generations. Average litter size in the control group declined significantly $(P<0.05)$ in the $F_{3(1)}$ generation, but there were no significant differences in average birth or weaning weights in the three generations of animals. In the BG group there 
TABIXS

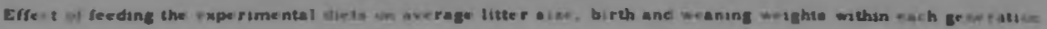

1

Det

Generation

$r_{1} \quad r_{2} \quad r_{3(1)}$

Weight of pupe at birch

Generation
Woyph of pupe at weraning

Gemeration

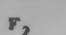

\section{Control}

1, 3-Butylene Giyeal

1. 3-Butylene Glycal Mono-Olente

1, 3-Buplese Giyeal Mono-Stearate
$12.611 . q^{2}(3)^{3}$ 9. 3t0. $7^{2}$ (9) $7.011 .8^{20}(6)$

$11.1 \pm 0.8^{2}$ (7) $9.8 \pm 0 . g^{2}(8) \quad 9.6 \pm 0.7^{2}(9) \quad 8.0 \pm 1 . g^{2}(1)$

9. $4 \pm 1.0^{2}(7) \quad 7.9 \pm 1.1^{*}(8) \quad 7.3^{ \pm}+1.3^{*}(8) \quad \ldots .$.

$12.0 \pm 1.1^{*}(6) \quad 9.4 \pm 0.0^{*}(9) \quad 9.6 \pm 1.2^{4}(7) \quad 6.7^{*}+1.1^{*}(7)$
6. $1 \pm 0.3 *(3) \quad 6.6 \pm 0.1^{ \pm}(9) \quad 6.1 \pm 0.2^{*}(6)$

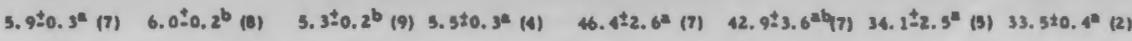

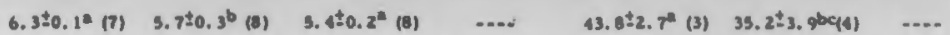

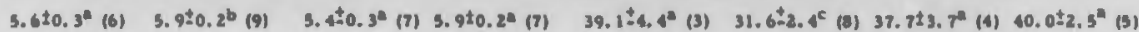

12 Second thetere of $F_{2}$ animule.

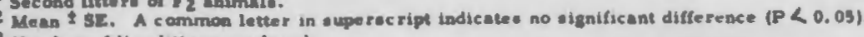

4 Number of litters weaned at 21 derp.

\section{TABLE 6}

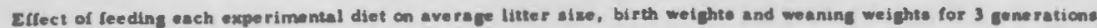

\begin{tabular}{|c|c|c|c|c|c|c|c|c|c|c|c|c|}
\hline \multirow[b]{2}{*}{$\begin{array}{l}\text { Coseretion } \\
\text { of yourits }\end{array}$} & \multicolumn{3}{|c|}{ Control } & \multicolumn{3}{|c|}{ 1. 3-Bulylene Gircol } & \multicolumn{3}{|c|}{ 1, 3-8usylene Giycol Mono-Olente } & \multicolumn{3}{|c|}{ 1, 1-Burylene Gircol Mono-Stearate } \\
\hline & $\begin{array}{l}\text { No. of live } \\
\text { pupe / litte r }\end{array}$ & Birth & $\underset{\omega t}{\text { Woening }}$ & $\begin{array}{l}\text { No. of live } \\
\text { pupa / IItter }\end{array}$ & $\begin{array}{c}\text { Birth } \\
\text {-t }\end{array}$ & $\begin{array}{c}\text { Weaning } \\
\text { wt }\end{array}$ & $\begin{array}{l}\text { No. of live } \\
\text { pups/liter }\end{array}$ & $\begin{array}{l}\text { Birth } \\
\mathbf{w t}\end{array}$ & Woenday & $\begin{array}{l}\text { No. of live } \\
\text { pupe / Iitites }\end{array}$ & $\begin{array}{c}\text { Birth } \\
\text { tt }\end{array}$ & Weandes \\
\hline & & 8 & - & & • & - & & - & - & & - & s \\
\hline $\mathbf{r}_{1}$ & $12.6 \pm 1.99^{1}(3)^{2}$ & $6.1 \pm 0.3^{*}(3)$ & $50.5^{ \pm}-4.6^{\circ}$ (3) & $11.11^{2}$ & 3. $9 \pm 0.3^{\text {t }}(7)$ & $46.4^{ \pm 2 .} 6^{4}(7)$ & 9. $4 \pm_{1,0^{\infty}}(7)$ & $6.3 t_{0.1}(7)$ & 43. $0 \pm 2.7^{n}(3)$ & $12.0 \pm 1.1^{2}(6)$ & $3.6 \pm 0.3^{2}(6)$ & $39.1 \pm 4.4^{4}(3)$ \\
\hline$r_{2}$ & $9.3 \pm 0.7 \times(9)$ & $6.6-0.1^{*}(9)$ & $4.2 \pm 1.3^{2}(4)$ & $9.0 \pm 0.95(8)$ & $6.0^{ \pm} 0.2^{2}(8)$ & $42.9 \pm 3.6^{2} ! 717$ & $7.9 \pm 1.1^{\star}(8)$ & $3.7 \pm 0.3^{26}(9)$ & $33.2 \pm 3.9^{2}(4)$ & $9.4 \pm 0.0^{-14}(9)$ & $3.9 \pm 0.2^{ \pm}(9)$ & $31.6 \pm 2.4^{2}(0)$ \\
\hline$r_{3(1)}$ & $7.0^{ \pm} \pm 1.0^{b}$ (6) & $6.1^{ \pm} 0.2^{2}(6)$ & 45. $0 \pm 0.0^{2}(1)$ & $9.6 \pm 0.7^{n}(9)$ & $3.3 \pm 0.2^{b}(9)$ & $34.1^{ \pm} 2.5^{b}(3)$ & 7. $3 \pm 1.3^{n}(0)$ & $9.4 \pm 0.2^{b}(8)$ & $\cdots$ & $7.6^{ \pm} 1.2^{6}(7)$ & $5.4 \pm 0.3^{2}(7)$ & $37.743 .7^{2}(4)$ \\
\hline$F_{3(z)^{3}}$ & $\cdots$ & .... & $\cdots$ & $2.8 \pm 1,3^{n}(6)$ & 5. 5to. $3^{*}(4)$ & $33.5 \pm 0.4^{6}(2)$ & $\cdots$ & $\cdots$ & $\cdots$ & $6.7 \pm 1.1^{6}(7)$ & 5. $9 \pm 0.2^{\text {a }}(7)$ & 40. $012.5^{n}(5)$ \\
\hline
\end{tabular}

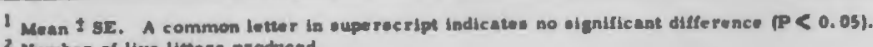
2 Mumber of live littore produced. 
were no significant differences in average litter size in all generations, but the re were significant differences $(P<0.05)$ in average birth and weaning weights, as these decreased in the $F_{3(1)}$ and $F_{3(2)}$ generations. Litter size in the BGMO group did not differ simificantly for three generations. While there was a significant difference in average birth weights between the $F_{1}$ and $F_{3}$ generations, no $\mathrm{F}_{3}$ animals survived to weaning. Average weaning weights for the first and second generations were similar. In the BGMS group average litter size was significantly greater in the $F_{1}$ than in the succeeding two generations. There were no significant differences in average birth or weaning weights in all generations of the BGMS animals.

Litter size, birth and weaning weights generally declined for all dietary treatment groups with succeeding generations, but these differences were usually not significant. In addition, there were no malformations or evidence of disease noted in any generation of litters in any of the diet groups except for the incidence of $r$ ing tail in three $B G M O\left(F_{1}\right)$ litters, one $B G\left(F_{1}\right)$ litter and one control $\left(F_{1}\right)$ litter. All of these animals survived with the exception of two BGMO litters. Thereafter, the humidity of the animal quarters was increased, and this prevented the occurrence of ring tail. Necropsies of the still-born and day-old infants showed what appeared to be liver enlargement in some samples, but this was evenly distributed throughout all treatment groups. In most cases, the 
pups which failed to survive to weaning had no milk in their alimentary tracts.

Food Ponsumption and Growth of Young Litters

The results of feeding the experimental diets to each generation of young litters from four to eight weeks of age are presented in Table 7. The highest average body weight gain was made by the control group for three generations, and the lowest average body weight gain was made by the BGMS group. However, the differences were only significant $(P<0.05)$ in the $F_{2}$ generation. The weight gains made by the BG and BGMO animals were similar in all generations.

A similar pattern was observed for food intake. Rats fed the control diet consumed significantly more food $(P<0.05)$ in the first two generations than rats fed the other three diets. Apparently, the control diet was more palatible than the experimental diets. There were little or no significant differences in intake between the other three diet groups.

Although the weight gains and the food intake in the three groups fed the synthetic compounds were lower than the control group, it is maportant to note that all diet groups had essentially the same food efficiencies. These results indicate normal utilization of the diets which contained BG, BGMO and BGMS. The observations on 
TABLI 7

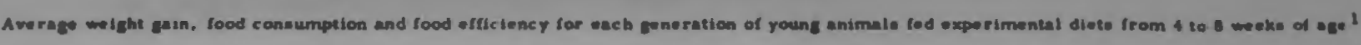

\begin{tabular}{|c|c|c|c|c|c|c|c|c|c|c|c|c|}
\hline \multirow[t]{3}{*}{ Dies } & \multirow[b]{3}{*}{$F_{1}$} & \multicolumn{2}{|c|}{ Average watighe gain per ansmal } & \multirow[b]{3}{*}{$r_{3(2)^{2}}$} & \multirow{2}{*}{\multicolumn{4}{|c|}{$\frac{\text { Averege food consumption per anjmal }}{\text { Geseretion }}$}} & \multirow{2}{*}{\multicolumn{4}{|c|}{ 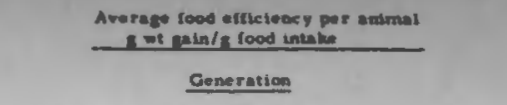 }} \\
\hline & & \multicolumn{2}{|l|}{ Generation } & & & & & & & & & \\
\hline & & $\boldsymbol{r}_{2}$ & $F_{3(1)}$ & & $r_{1}$ & $F_{2}$ & $F_{3(1)}$ & $r_{3(2)}$ & $r_{1}$ & $r_{2}$ & $r_{3(1)}$ & $F_{3(2)}$ \\
\hline Control & $113^{ \pm}=10.2^{\mathrm{m}^{3}}(3)^{4}(30)^{5}$ & $154^{ \pm t} .1^{*}(4)(32)$ & $168 \pm 0.091)(8)$ & $\cdots$ & $260^{ \pm} 4.2^{\mathrm{m}}$ & $320 \pm 14.1 *$ & $321+00.0$ & $\cdots$ & $0.44 \div 0.0$ & 0.4010 .0 & $0.52 \pm 0.00$ & $\ldots$ \\
\hline 1. 3. Busylese Oigeol & $101 \div 7.7^{\circ}(7)(66)$ & $122 \pm 2,7^{6}(7)(62)$ & $107^{ \pm} 11.3^{34}(3)(32)$ & $118^{4} 4.0^{\circ}(2)(16)$ & $197 \pm 10.7 \mathrm{~b}$ & $240^{ \pm} 12.1^{\circ}$ & $254^{ \pm} 10.0^{*}$ & $236 \pm 00.0^{2}$ & $0.50 \pm 0.1$ & $0.32 \pm 0.0^{2}$ & $0.440 .1^{*}$ & $0.50 \pm 0.0^{2}$ \\
\hline $\begin{array}{l}\text { 1, M-Butylene Giycal } \\
\text { Mono-Oleate }\end{array}$ & $201 \pm 15,0^{8}(3)(28)$ & $123 \pm . .1^{b}(4)(31)$ & $\cdots$ & $\cdots$ & $190^{ \pm} 18.5^{b}$ & $231 \pm 12.4^{\text {be }}$ & $\cdots$ & $\cdots$ & $0.31 \pm 0.00$ & $0.54 \pm 0.00$ & $\cdots$ & $\cdots$ \\
\hline $\begin{array}{l}\text { 1. 3-Butylese Olyeol } \\
\text { Mono-Srearaze }\end{array}$ & $70 \pm 10.7^{a}(3)(24)$ & $106 \pm 4.3^{c}(8)(71)$ & $110 \pm 11.143)(18)$ & $116 \pm 9.3^{*}$ (5) (28) & $214^{ \pm 22.906}$ & $203 \pm 6.05$ & $252 \pm 29.5^{\circ}$ & $252 \pm 13.0^{2}$ & $0.37 \pm 0.5^{*}$ & $0.32 \pm 0.0^{\pi}$ & $0.44 \pm 0.0$ & $0.46 \pm 0.0^{4}$ \\
\hline
\end{tabular}

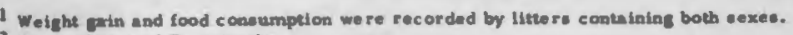

2 Second litues of $\boldsymbol{F}_{2}$ animale.

5 Number of tirtersi.

\section{TABLE 8}

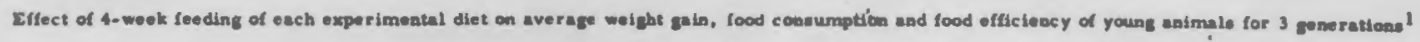

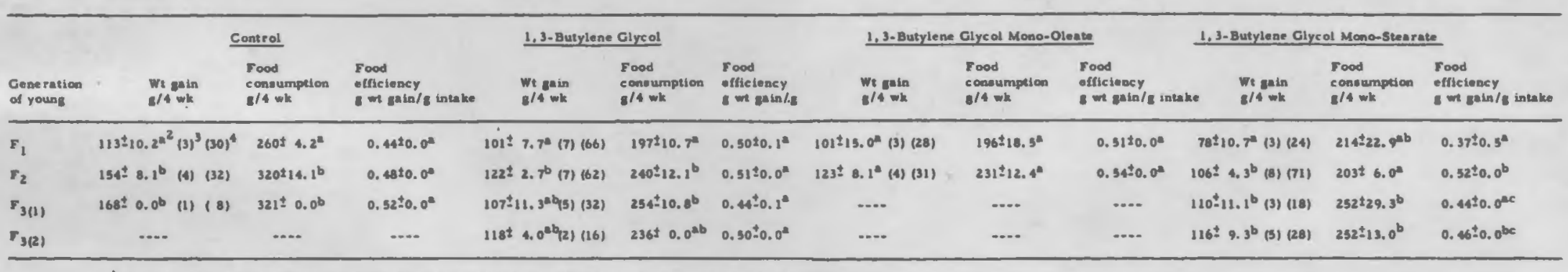

1 Weight gain and lood consumpetion were recorded by litters containing boch sexee, 4 to 8 weeke of age.

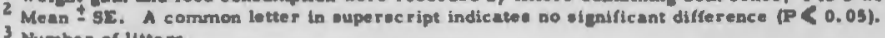

Number of littert.

5 sec ond litter of $r$, animalo. 
$B G$ are in $\mathrm{g}_{\mathrm{g}} \mathrm{reement}$ with the findings of Miller and Dymsza (39) and Mehlman et al. (34) with rats fed $20 \%$ levels of 1,3-Butylene Glycol.

The food intake of the $F_{1}$ generation of BGMS animals was rather high with a corresponding rather low food efficiency ratio. These results can be explained by the fact there was some loss of this particular diet which tended to be chunk-like. Pulverizing the diet so that the animals could not remove it from their feeding dishes essentially solved the diet spillage problem.

The effect of an early four-week period of feeding each diet on weight gain, food consumption and food efficiency for the $F_{1}, F_{2}$ and $F_{3}$ generations is shown in Table 8 . The purpose is to show the change, if any, on the same parameter with each succeeding generation. Average weight gain and food consumption for the control group were significantly higher in the $\mathrm{F}_{2}$ and $\mathrm{F}_{3}$ generations than in the $F_{1}$ generation. A similar pattern was observed in most generations for the three experimental diet groups, although there were a few significant differences, and there was no $F_{3}$ BGMO group for comparison. However, food efficiencies within each diet group did not change appreciably from one generation to another.

Speculation could be made that the increase in both weight gain and food consumption in succeeding generations of surviving animals consuming the experimental diets was due to the development 
of adaptative mechanisms, but this is not a valid suggestion, as the same results were observed in the control animals.

The appearance of the young animals was interesting because the control and the BG animals appeared healthy in all respects and had thick, clean white coats of fur, whereas the young BGMO and BGMS animals were thin with sparse fur which was oily from physical contact with the diet upon eating. However, by eight weeks of age the fur of these animals was of normal thickness and color, and they appeared essentially as healthy as the control and BG rats.

Adult Weight Gains and Terminal Body Weights

After eight weeks of age, food consumption and weight gain records were kept for the animals chosen as breeders. The other animals were discarded. No special selection of breeders was made in the $F_{3}$ generation because all the $F_{3(1)}$ animals were saved while the $F_{3(2)}$ animals were maintained only to 15 weeks of age. Therefore, the data presented in the tables on the adult animals in the $F_{3}$ generation are observations made on the $F_{3(1)}$ animals. Only the weight gains of the male rats in each generation were chosen for statistical analysis. Food consumption and weight gain records of the female rats are not shown, as they were difficult to interpret because these animals were in the process of being bred or were producing and raising litters.

Average weight gain for each generation of male rats fed 
the experimental diets from eight to 24 weeks of age is presented in Table 9. The results obtained from this experiment do not follow the same pattern as the results obtained from the preceding experiment (Table 7), when the same diets were fed to young litters from four to eight weeks of age. During the eight to 24-week feeding period, weight gains for the controls were seldom higher than the other diet groups in all the generations. In the $F_{0}$ parent generation, the $B G$ males had a significantly higher weight gain $(P<0.05)$ than males in the other groups. This observation may not be as mignificant as it appears, as one of the two animals was extremely obese. However, the same pattern appeared again in the $F_{1}$ generation (five animals per group), where the BG males again had the highest weight gain. The trend was reversed in the $F_{2}$ generation where the controls gained the most weight, but their weight gain was not significantly different from that made by the $\mathrm{BG}$ or the $\mathrm{BGMS}$ males. In the $\mathrm{F}_{3}$ generation the $\mathrm{BG}$ males had the lowest average weight gain of all groups. The average weight gain of the BGMO and BGMS males fluctuated from one generation to another. Generally the BGMO group had low weight gains, but these were not always significantly lower than the other groups. While the BGMS males had weight gains similar to the controls in the $F_{0}, F_{2}$ and $F_{3}$ generations, their average weight gain in the $F_{1}$ generation was significantly lower $(P<0.05)$ than the control and BG diet groups. 


\section{TABLE 9}

Average weight gain for each generation of male rats fed the experimental diets from 8 to 24 weeks of age

\section{Generation}

\section{$F_{0}$}

Diet

No.

rats
$F_{1}$

No.

rats Wt gain/16 wk
No. rats

$$
\mathrm{F}_{2}
$$

$\mathrm{F}_{3}$

\begin{tabular}{|c|c|c|c|c|c|c|c|c|}
\hline & & g & & g & & g & & g \\
\hline Control & 2 & $408 \pm 26.2^{a^{1}}$ & 5 & $379 \pm 10.2^{\mathrm{ab}}$ & 5 & $397^{ \pm}-45.0^{a}$ & 4 & $385^{ \pm} 23.5^{\mathrm{ab}}$ \\
\hline$B G^{2}$ & 2 & $534 \pm 95.2^{b}$ & 5 & $446 \pm 38.4^{a}$ & 5 & $333 \pm 10.2^{\mathrm{ab}}$ & 16 & $317^{ \pm 16.7^{a}}$ \\
\hline $\mathrm{BGMO}^{3}$ & 2 & $381 \pm 82.0^{a}$ & 5 & $337^{t}-12.8^{b c}$ & 5 & $320 \pm 14.0^{b}$ & -- & --- \\
\hline $\mathrm{BGMS}^{4}$ & 2 & $404 \pm 11.5^{a}$ & 4 & $303^{t}-28.1^{c}$ & 5 & $372 \pm 25.2^{a}$ & 7 & $393^{ \pm}-14.3^{b}$ \\
\hline
\end{tabular}

${ }^{1}$ Mean $\pm \mathrm{SE}$. A common letter in superscript indicates no significant difference $(\mathrm{P}<0.05)$.

2 1, 3-Butylene Glycol.

3 1,3-Butylene Glycol Mono-Oleate.

4 1,3-Butylene Glycol Mono-Stearate. 
Table 10 shows the result of feeding each particular diet on the average weight gain of male rats during the same 16-week feeding period as above for succeeding $F_{1}, F_{2}$ and $F_{3}$ generations. In the control and BGMO groups, there were no significant changes from generation to generation, whereas the average weight gain for the $B G$ males declined significantly $(P<0.05)$ in the $F_{2}$ and $F_{3}$ generations. The average weight gain for the BGMS males was similar in all generations except the $F_{1}$ generation where the weight gain was significantly lower $(P<0.05)$.

Average weight gain from eight to 24 weeks of age for the $F_{2}$ generation of male rats is presented in Figure 1. Total weight gains are also shown in this figure, so that the results are easier to interpret. In this particular $\mathrm{F}_{2}$ generation, the control group had the highest average weaning weight at three weeks (Table 5) and the highest average weight gain at eight weeks (Table 7), whereas the BGMS group had the lowest average weight and weight gains for the same period. Although the weight gains of both groups were similar during the latter eight to 24-week period (Table 9), the controls, because of their initial weight gains, had a total weight gain for 24 weeks that was significantly higher $(\mathrm{P}<0.05)$ than the BGMS males (Table 11). The total weight gain of the controls was also significantly higher than the BGMO males but not significantly different from the males in the BG group. 
TABLE 10

Effect of 16-week feeding of each experimental diet on average weight gain of male rats for 4 generations 1

\begin{tabular}{|c|c|c|c|c|c|c|c|c|}
\hline \multirow[t]{2}{*}{ Generation } & \multicolumn{2}{|c|}{ Control } & \multicolumn{2}{|c|}{ 1,3-Butylene Glycol } & \multicolumn{2}{|c|}{$\begin{array}{l}\text { 1,3-Butylene Glycol } \\
\text { Mono-Oleate }\end{array}$} & \multicolumn{2}{|c|}{$\begin{array}{c}\text { 1,3-Butylene Glycol } \\
\text { Mono-Stearate }\end{array}$} \\
\hline & $\begin{array}{l}\text { No. } \\
\text { rats }\end{array}$ & Wt gain/16 wk & $\begin{array}{l}\text { No. } \\
\text { rats }\end{array}$ & Wt gain/16 wk & $\begin{array}{l}\text { No. } \\
\text { rats }\end{array}$ & Wt gain/16 wk & $\begin{array}{l}\text { No. } \\
\text { rats }\end{array}$ & Wt gain $/ 16$ wk \\
\hline & & g & & g & & g & & g \\
\hline$F_{0}$ & 2 & $408 \pm 26.2^{\mathrm{a}^{2}}$ & 2 & $534-95.2^{a}$ & 2 & $381 \pm 82.0^{\mathrm{a}}$ & 2 & $404 \pm 11.5^{\mathrm{a}}$ \\
\hline$F_{1}$ & 5 & $379 \pm 10.2^{\mathrm{a}}$ & 5 & $446 \pm 38.4^{a}$ & 5 & $337^{+}-12.8^{a}$ & 4 & $303^{t}-28.1^{b}$ \\
\hline$F_{2}$ & 5 & $398 \pm 45.0^{a}$ & 5 & $333^{+}-10.2^{b}$ & 5 & $320 \pm 14.0^{a}$ & 5 & $372 \pm 25.3^{\mathrm{a}}$ \\
\hline$F_{3}$ & 4 & $385 \pm 23.5^{\mathrm{a}}$ & 16 & $317^{ \pm}-16.6^{b}$ & -- & --- & 7 & $393 \pm 14.3^{\mathrm{a}}$ \\
\hline
\end{tabular}

1

Rats fed diets from 8 to 24 weeks of age.

2 Mean \pm SE. A common letter in superscript indicates no significant difference $(\mathrm{P}<0.05)$. 


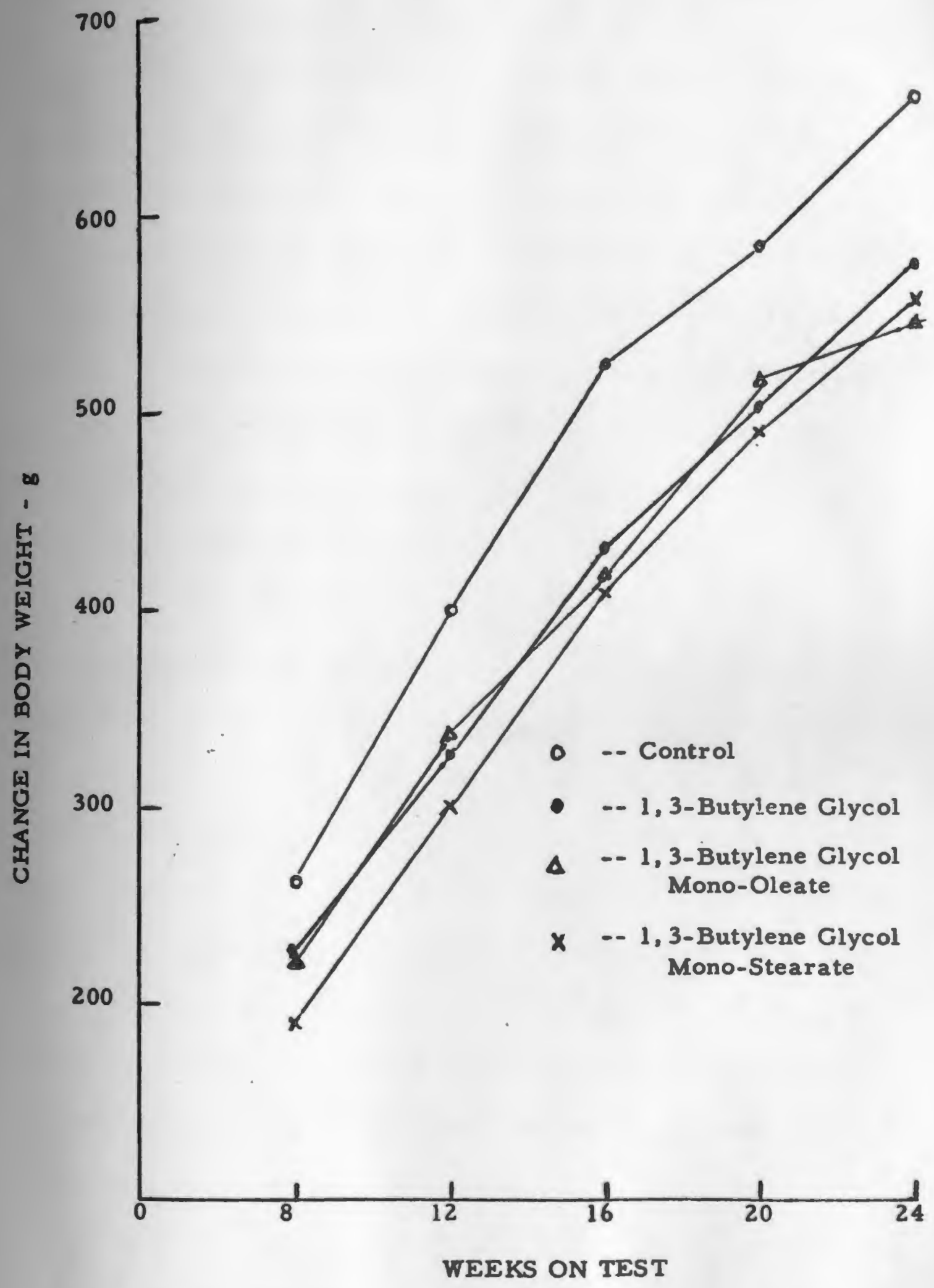

Fig. 1 Average weight gain of $F_{2}$ male rats fed the experimental diets from 8 to 24 weeks of age 
Table 11, which presents data on terminal adult body weights at 24 weeks of age for each generation, indicates that similar results were obtained in all generations of male animals. The control and BG males were often heavier, but not always significantly heavier than the BGMO and BGMS males. The same pattern generally exists for the $F_{0}$ and $F_{1}$ generations of female rats. However, in the $\mathrm{F}_{2}$ and $\mathrm{F}_{3}$ generations, the average terminal body weight of the $B G$ females was significantly lower $(P<0.05)$ than the controls. There were no significant differences between the weights of the females in the BGMO and BGMS groups.

The effect of feeding each diet on terminal body weights for four generations is shown in Table 12. The control diet produced no significant difference in the average terminal weights of the male rats from the $\mathrm{F}_{0}$ to the $\mathrm{F}_{3}$ generations but there were significant weight differences between the generations of female animals. The results were reversed in the BG group. Terminal weights of the various generations of female rats were similar with one exception, the $\mathrm{F}_{3}$ generation, but there were significant differences between the generations of male rats. The diets containing BGMO and BGMS had little or no effect on the terminal body weights of either males or females from generation $\mathrm{F}_{0}$ to generation $\mathrm{F}_{3}$.

From the data in Tables 11 and 12 it can be concluded that the female rats fed the control diet had heavier terminal 24-week 


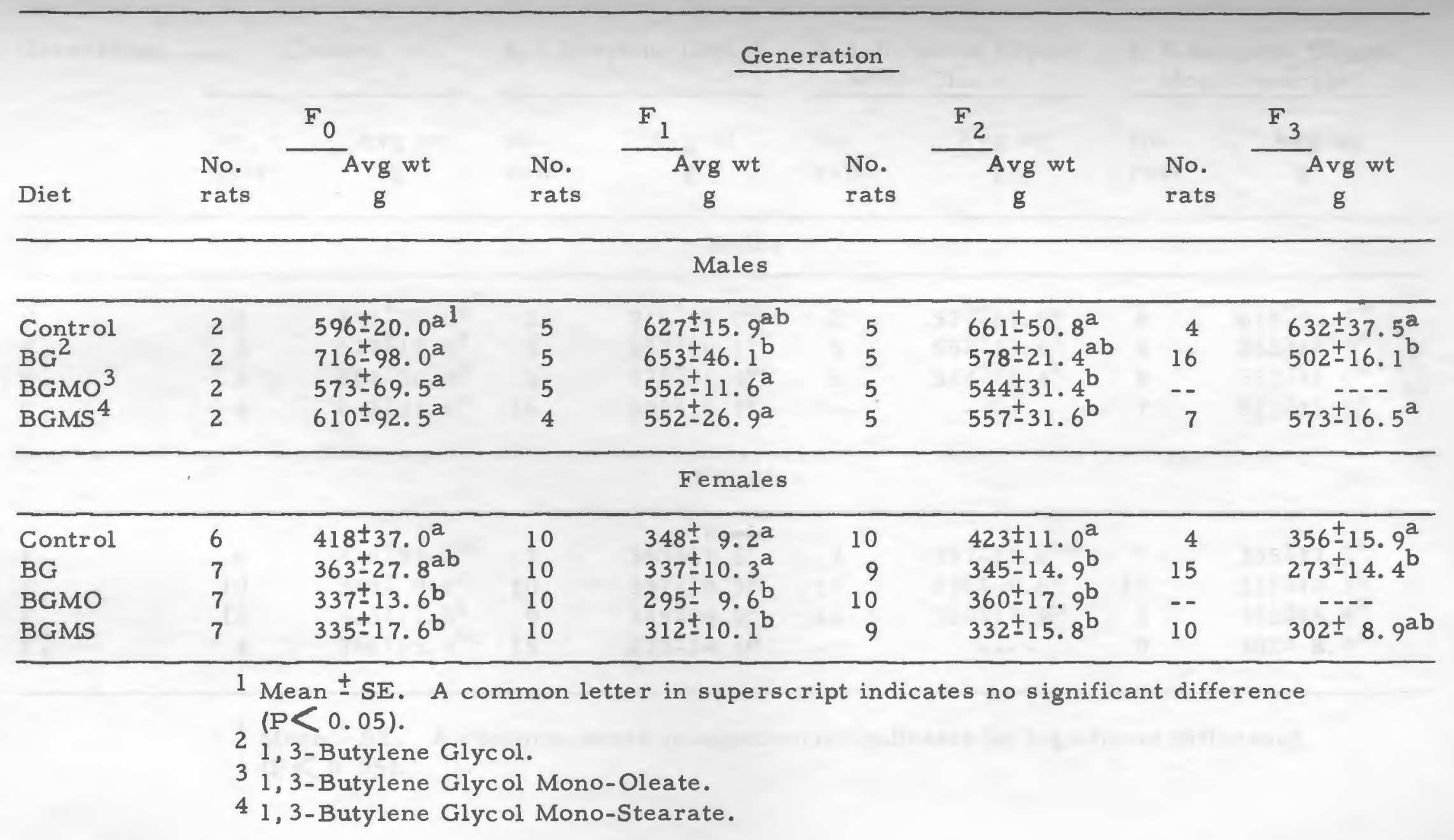


TABLE 12

Effect of feeding each experimental diet on terminal adult rat body weights for 4 generations

\begin{tabular}{|c|c|c|c|c|c|c|c|c|}
\hline \multirow[t]{2}{*}{ Generation } & \multicolumn{2}{|c|}{ Control } & \multicolumn{2}{|c|}{ 1,3-Butylene Glycol } & \multicolumn{2}{|c|}{$\begin{array}{l}\text { 1,3-Butylene Glycol } \\
\text { Mono-Oleate }\end{array}$} & \multicolumn{2}{|c|}{$\begin{array}{l}\text { 1, 3-Butylene Glyco } \\
\text { Mono-Stearate }\end{array}$} \\
\hline & $\begin{array}{l}\text { No. } \\
\text { rats }\end{array}$ & $\begin{array}{l}\text { Avg wt } \\
g\end{array}$ & $\begin{array}{l}\text { No. } \\
\text { rats }\end{array}$ & $\begin{array}{l}\text { Avg wt } \\
g\end{array}$ & $\begin{array}{l}\text { No. } \\
\text { rats }\end{array}$ & $\begin{array}{l}\text { Avg wt } \\
\text { g }\end{array}$ & $\begin{array}{l}\text { No. } \\
\text { rats }\end{array}$ & $\begin{array}{l}\text { Avg wt } \\
g\end{array}$ \\
\hline
\end{tabular}

Males

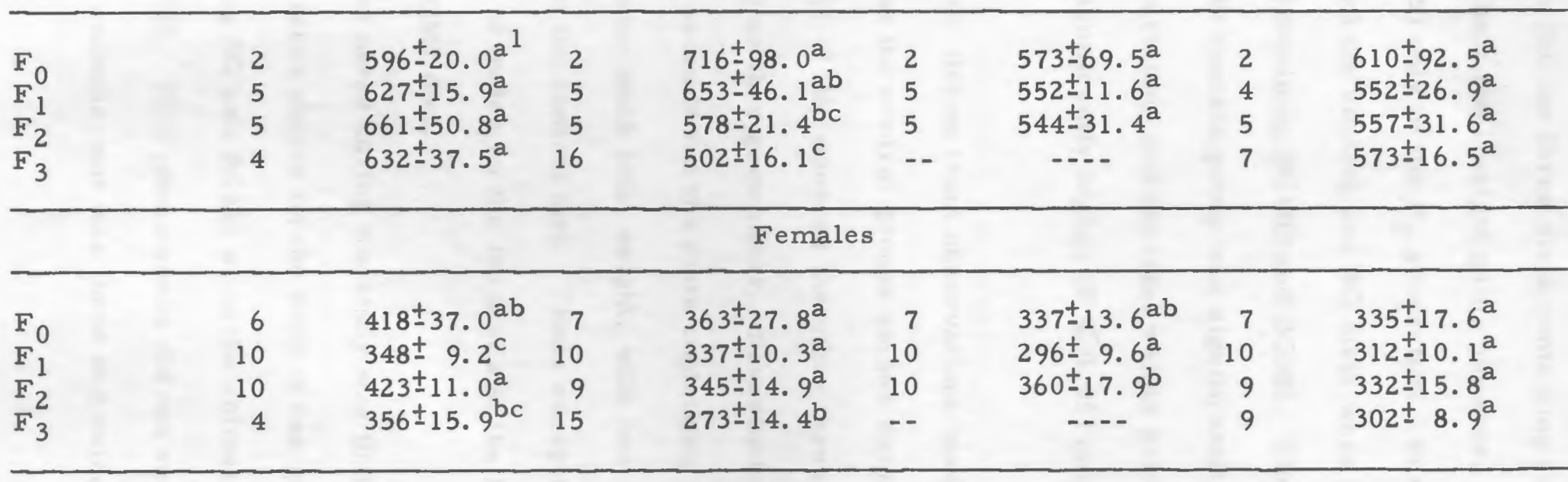

1 Mean \pm SE. A common letter in superscript indicates no significant difference $(\mathrm{P}<0.05)$. 
body weights than the females fed the three diets containing the syathetic test compounds. Their total weight gain, however, was significantly higher $(P<0.05)$ only in the $F_{2}$ generation. In most generations, the male rats fed the control and $B G$ diets were heavier than the males fed the diets containing BGMO and BGMS. The total weight gain of the males in the control group was significantly higher $(P<0.05)$ only in the $F_{2}$ generation, and the total weight gain of the males in the $B G$ group was significantly higher $(P<0.05)$ only in the $F_{1}$ generation.

A second conclusion, drawn from observations made while caring for the animals, is that the control groups gained weight more rapidly during the early weeks of life whereas the other three groups gained weight more gradually as they grew older. Nevertheless, as indicated in Table 11 , the animals fed the diets containing BG, BGMO and BGMS did not gain as much total weight, with two exceptions, as the animals on the control diet. These exceptions were in the $F_{0}$ and $F_{1}$ generations of males on the $B G$ diet and the $F_{0}$ generation of males on the BGMS diet.

Another observation noted during the study was that the fur disappeared in some scattered places on the body of two generations of rats fed the diets containing $B G$ and BGMS when the animals were approximately twelve weeks old. This phenomenon did not seem to be caused by fighting among the animals; nor was there any evidence of 
parasitic infection. The animals appeared healthy in all other respects, and within four to five weeks the fur grew back and was normal in appearance. The only differences noted in the behavior of the animals fed the experimental diets was that all the adult rats who had contracted ring tail disease as pups appeared more nervous and irritable. This created some difficulty in handling these few animals which had short stump tails instead of normal long tails.

\section{Terminal Organ Weights}

The organ weights, recorded for each generation at the termination of a 24-week experimental period and expressed as percentage of total body weight, are summarized in tables as follows: liver (Tables 13 and 14), kidneys (Tables 15 and 16), spleen (Tables 17 and 18), testes (Table 19) and epididymal fat tissue (Tables 20 and 21).

With respect to liver weights, the following statements may be drawn from examination of Table 13. Very few significant changes were seen in the four generations of male and female rats fed the experimental diets. In the $F_{1}$ generation, the liver weight of the female animals fed the BGMO diet and the liver weights of the males and females fed the BGMS diet were significantly higher $(P<0.05)$ than the other two diet groups. Nevertheless, when compared to the values reported by Kozma et al. (32) and Patel et al. (42), all livers were of normal weight and not enlarged. In addition, there were few 
Liver weights of adult rats fed experimental diets by generation ${ }^{1}$

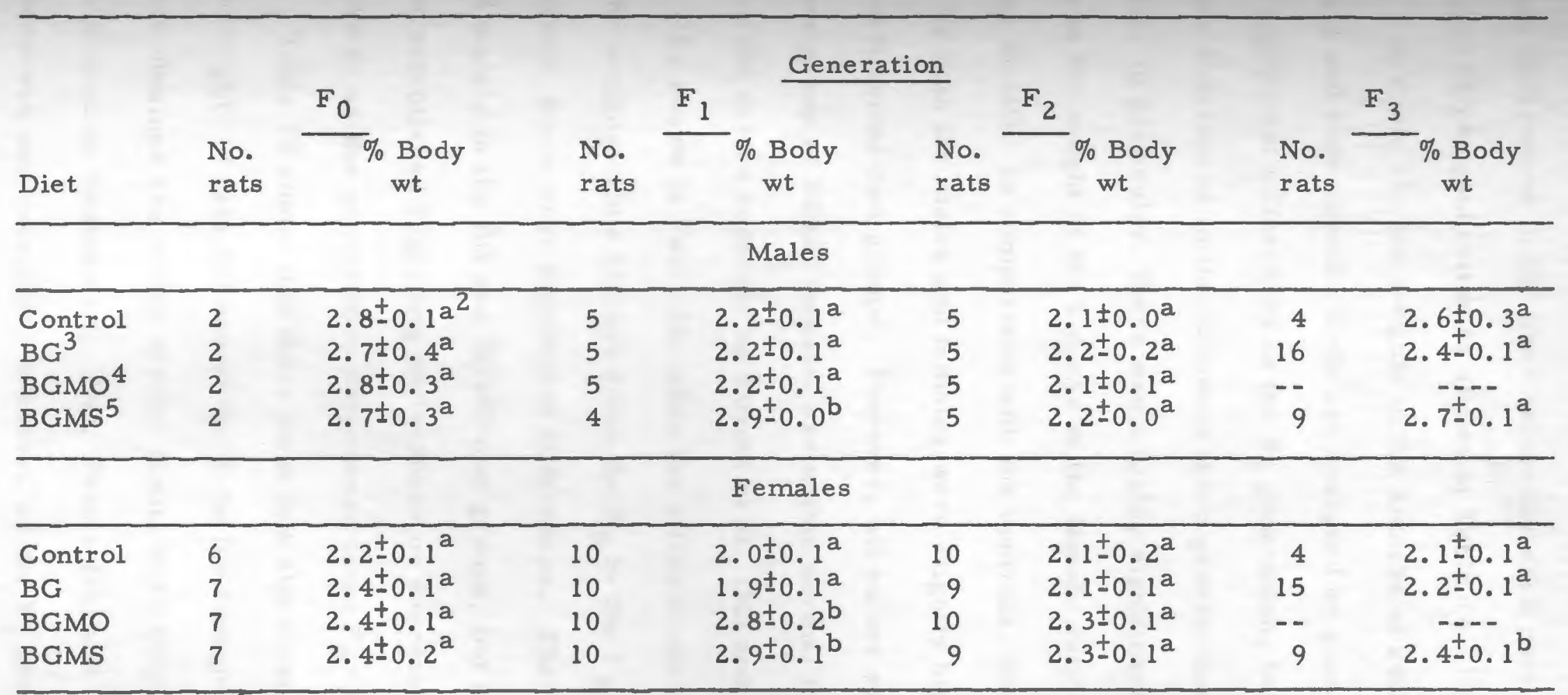

1 Expressed as \% of body weight of animals 24 weeks of age.

2 Mean $\pm \mathrm{SE}$. A common letter in superscript indicates no significant difference $3(\mathrm{P}<0.05)$.

3 1,3-Butylene Glycol.

4 1,3-Butylene Glycol Mono-Oleate.

5 1,3-Butylene Glycol Mono-Stearate. 
significant differences in the liver values for each particular diet from generation to generation as shown in Table 14.

In Table 15, the weights of the kidneys of adult rats fed the control and experimental diets are analyzed by generation. There were no significant differences in the $\mathrm{F}_{0}$ generation, but there were stgmificant differences in the following three generations. In the $F_{1}$ generation, in particular, there was a highly significant $(P<0.05)$ increase in the weight of the kidneys of the female rats fed the diet containing BGMO. In comparis on with the controls, the weights of the kidneys for both the males and females were slightly higher in the three experimental diet groups. However, all values except those for the one group of BGMO females are within normal limits as defined by the values reported by Kozma et al. (32) and Peters (44). As shown in Table 16, when the effect of each particular diet on the weights of the kidneys from the $\mathrm{F}_{0}$ to the $\mathrm{F}_{3}$ generation was analyzed, there were significant differences. These differences occurred mainly in the BG and BGMO diet groups, but no consistent trend was established regarding an increase or decrease in the weights of the Kidneys as the generations progressed from $\mathrm{F}_{0}$ to $\mathrm{F}_{3}$.

Table 17 shows that there were few significant differences in spleen weights of rats fed any of the diets for four generations. The values obtained are within normal limits when compared to the values published by Kozma et al. (32), Peters (45) and Webster et al. (60). There was one exception, however, as the $F_{1}$ generation of 
TABLE 14

Effect of feeding each experimental diet on liver weights of adult rats for 4 generations 1

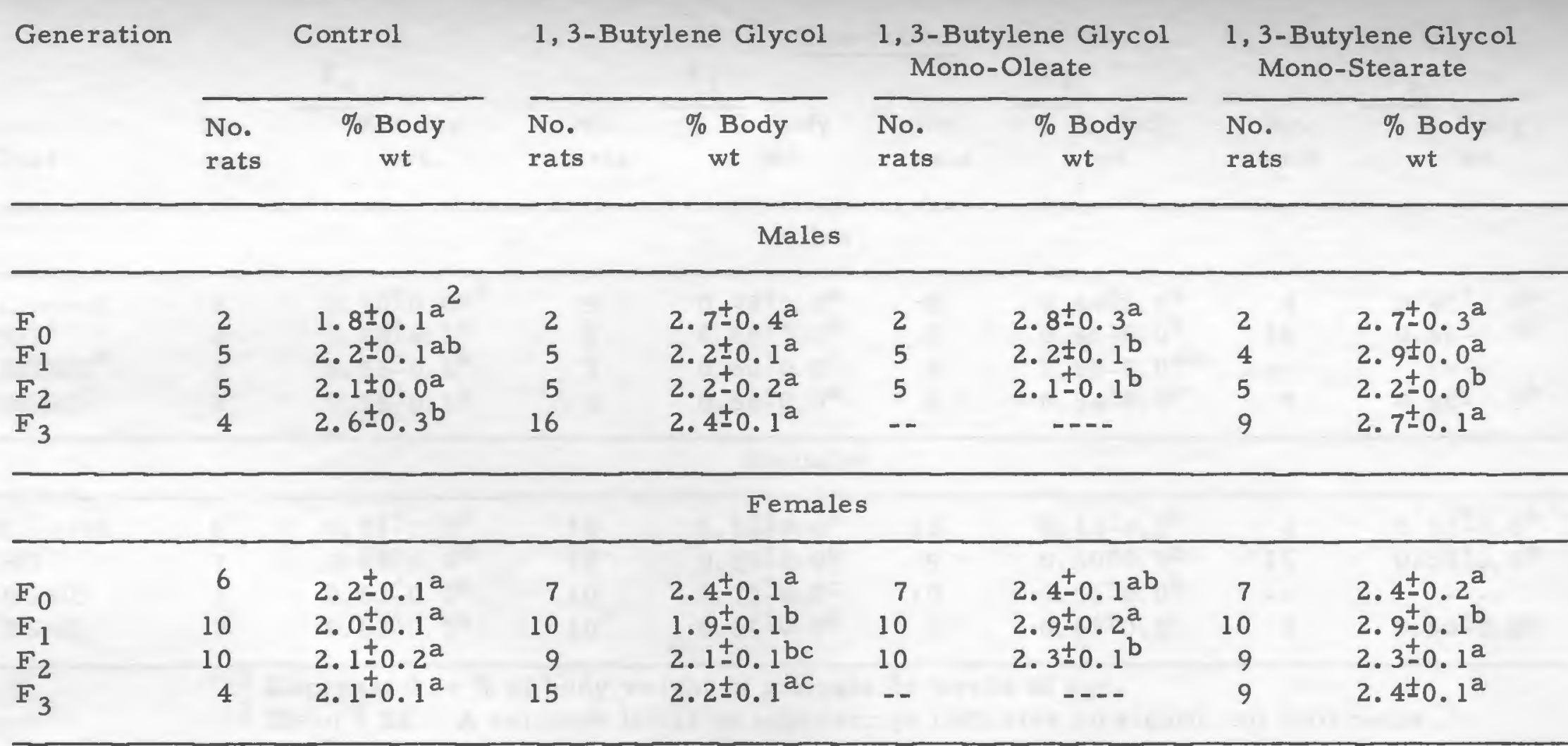

1 Expressed as \% of body weight of animals 24 weeks of age.

2 Mean $\pm S E$. A common letter in superscript indicates no significant difference $(P<0.05)$. 


\section{TABLE 15}

Weights of kidneys of adult rats fed experimental diets by generation 1

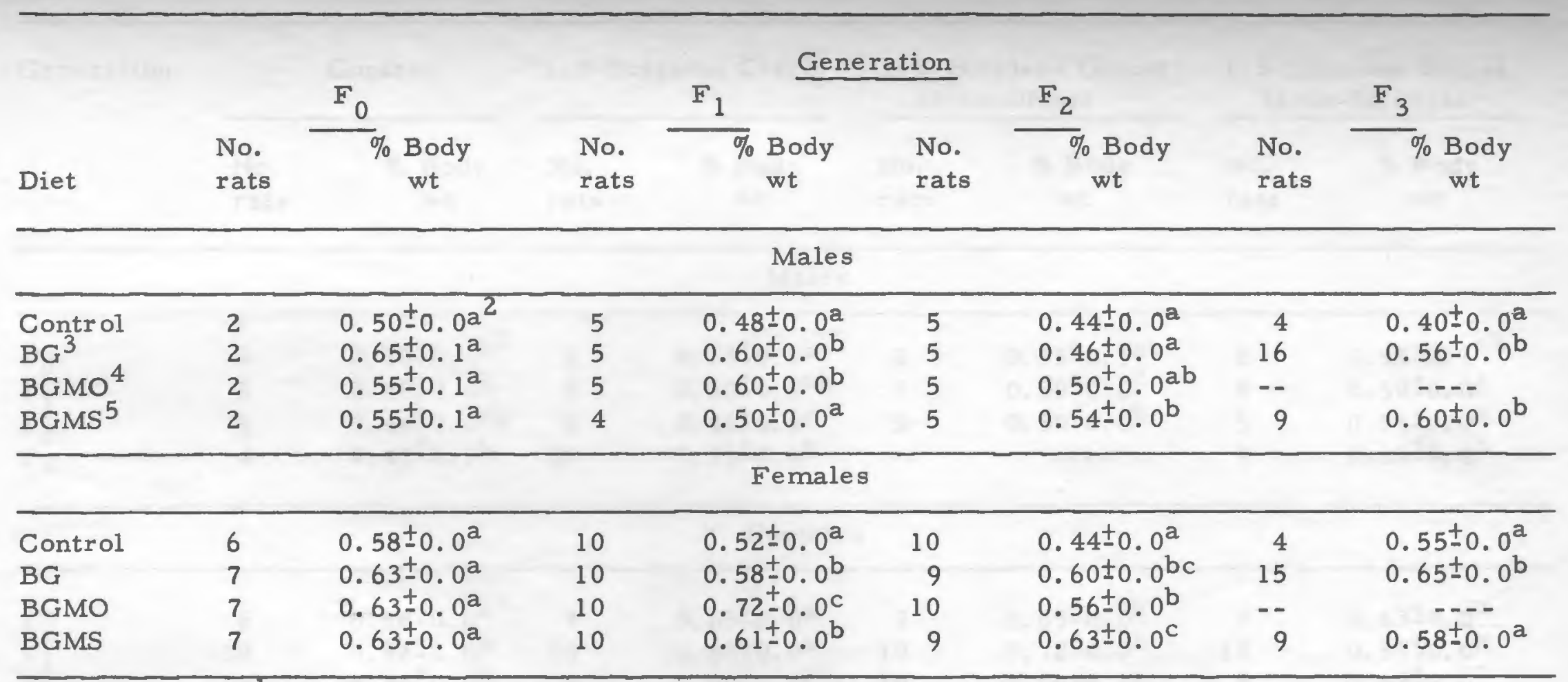

1 Expressed as \% of body weight of animals 24 weeks of age.

2 Mean $\pm \mathrm{SE}$. A common letter in superscript indicates no significant difference $(\mathrm{P}<0.05)$.

3 1,3-Butylene Glycol.

4 1,3-Butylene Glycol Mono-Oleate.

5 1,3-Butylene Glycol Mono-Stearate. 
TABLE 16

Effect of feeding each experimental diet on weights of kidneys of adult rats for 4 generations 1

Generation

Control

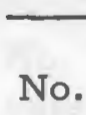

rats
$\%$ Body

wt
1, 3-Butylene Glycol

$\begin{array}{lc}\text { No. } & \% \text { Body } \\ \text { rats } & \text { wt }\end{array}$

1,3-Butylene Glycol Mono-Oleate

No.

rats
\% Body

wt
1,3-Butylene Glycol

Mono-Stearate

No.

rats
$\%$ Body wt

Males

\begin{tabular}{lllllllll}
\hline $\mathrm{F}_{0}$ & 2 & $0.50 \pm 0.0^{\mathrm{a}^{2}}$ & 2 & $0.65 \pm 0.1^{\mathrm{a}}$ & 2 & $0.55 \pm 0.1^{\mathrm{ab}}$ & 2 & $0.55^{\mathrm{b}} 0.1^{\mathrm{ab}}$ \\
$\mathrm{F}_{1}$ & 5 & $0.48 \pm 0.0^{\mathrm{a}}$ & 5 & $0.60 \pm 0.0^{\mathrm{ab}}$ & 5 & $0.60 \pm 0.0^{\mathrm{c}}$ & 4 & $0.50 \pm 0.0^{\mathrm{a}}$ \\
$\mathrm{F}_{2}$ & 5 & $0.44 \pm 0.0^{\mathrm{ab}}$ & 5 & $0.46 \pm 0.0^{\mathrm{c}}$ & 5 & $0.50 \pm 0.0^{\mathrm{b}}$ & 5 & $0.54 \pm 0.0^{\mathrm{a}}$ \\
$\mathrm{F}_{3}$ & 4 & $0.40 \pm 0.0^{\mathrm{b}}$ & 16 & $0.56 \pm 0.0^{\mathrm{b}}$ & -- & $-\ldots$ & 9
\end{tabular}

\section{Females}

$\begin{array}{lrrrlrrrrr}F_{0} & 6 & 0.58 \pm 0.0^{\mathrm{a}} & 7 & 0.63 \pm 0.0^{\mathrm{a}} & 7 & 0.63 \pm 0.0^{\mathrm{a}} & 7 & 0.63 \pm 0.0^{\mathrm{a}} \\ \mathrm{F}_{1} & 10 & 0.52 \pm 0.0^{\mathrm{a}} & 10 & 0.58 \pm 0.0^{\mathrm{a}} & 10 & 0.72 \pm 0.0^{\mathrm{b}} & 10 & 0.61 \pm 0.0^{\mathrm{a}} \\ \mathrm{F}_{2} & 10 & 0.44 \pm 0.0^{\mathrm{b}} & 9 & 0.60 \pm 0.0^{\mathrm{ab}} & 10 & 0.56 \pm 0.0^{\mathrm{c}} & 9 & 0.63 \pm 0.0^{\mathrm{a}} \\ \mathrm{F}_{3} & 4 & 0.55 \pm 0.0^{\mathrm{a}} & 15 & 0.65 \pm 0.0^{\mathrm{b}} & -- & -\ldots-0 & 9\end{array}$

1 Expressed as \% of body weight of animals 24 weeks of age.

2 Mean $\pm \mathrm{SE}$. A common letter in superscript indicates no significant difference $(\mathrm{P}<0.05)$. 
Spleen weights of adult rats fed experimental diets by generation ${ }^{1}$

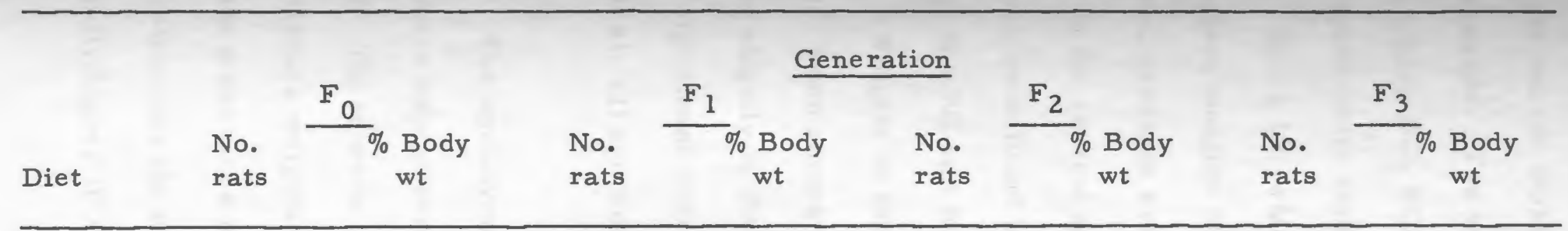

Males

\begin{tabular}{|c|c|c|c|c|c|c|c|c|}
\hline Control & 2 & $0.15 \pm 0.1 \mathrm{a}^{2}$ & $\begin{array}{l}5 \\
5\end{array}$ & $0.10 \pm 0.0 \mathrm{a}$ & $\begin{array}{l}5 \\
5\end{array}$ & $0.10 \pm 0.0^{\mathrm{a}}$ & 4 & $0.13 \pm 0.0^{a}$ \\
\hline $\begin{array}{l}\mathrm{BG}^{3} \\
\mathrm{BGMO}\end{array}$ & 2 & $0.20 \div 0.0^{a}$ & 5 & $0.20=0.0$ & 5 & $0.14 \pm 0.0 \mathrm{ab}$ & 16 & $0.19-0.0^{0}$ \\
\hline BGMS $^{5}$ & 2 & $0.20 \pm 0.0^{a}$ & $\begin{array}{l}5 \\
4\end{array}$ & $0.15 \pm 0.0^{c}$ & $\begin{array}{l}5 \\
5\end{array}$ & $0.16 \pm 0.0^{b}$ & 9 & $0.20 \pm 0.0^{b}$ \\
\hline
\end{tabular}

Females

\begin{tabular}{lllllrrrrr}
\hline Control & 6 & $0.22 \pm 0.0^{\mathrm{a}}$ & 10 & $0.12 \pm 0.0^{\mathrm{a}}$ & 10 & $0.11 \pm 0.0^{\mathrm{a}}$ & 4 & $0.20^{ \pm 0.0^{\mathrm{a}}}$ \\
BG & 7 & $0.23 \pm 0.0^{\mathrm{a}}$ & 10 & $0.16 \pm 0.0^{\mathrm{b}}$ & 9 & $0.14 \pm 0.0^{\mathrm{ab}}$ & 15 & $0.24 \pm 0.0^{\mathrm{a}}$ \\
BGMO & 7 & $0.20 \pm 0.0^{\mathrm{a}}$ & 10 & $0.30 \pm 0.0^{\mathrm{c}}$ & 10 & $0.19 \pm 0.0^{\mathrm{b}}$ & -- & ---- \\
BGMS & 7 & $0.21 \pm 0.0^{\mathrm{a}}$ & 10 & $0.19 \pm 0.0^{\mathrm{b}}$ & 9 & $0.19 \pm 0.0^{\mathrm{b}}$ & 9 & $0.21 \pm 0.0^{\mathrm{a}}$ \\
\hline
\end{tabular}

1 Expressed as \% of body weight of animals 24 weeks of age.

2 Mean \pm SE. A common letter in superscript indicates no significant difference $(\mathrm{P}<0.05)$.

3 1,3-Butylene Glycol.

4 1,3-Butylene Glycol Mono-Oleate.

5 1,3-Butylene Glycol Mono-Stearate. 
female rats fed the BGMO diet had a significant increase $(P<0.05)$ in spleen weight. The weights of the spleens of animals fed the three diets containing $B G, B G M O$ and $B G M S$ were slightly higher, but not always significantly higher, than the animals fed the control diet.

Table 18, which shows the effect of feeding each particular diet on spleen weights of adult rats from generation to succeeding generation, presents evidence that the spleen weights remained fairly constant in the control and BGMS groups. A few significant differences were found in spleen values from one generation to another in the BG and BGMO groups.

Weights of the testes for the $\mathrm{F}_{2}$ generation are shown in Table 19. When compared to the controls, the weights of the testes increased slightly in the BG, BGMO and BGMS diet groups, but there were no significant differences. In accordance with the reports of Adams et al. (1) and Kozma et al. (32) the values are within normal limits.

The epididymal fat pad weights of male rats fed the control and the three experimental diets for four generations is presented in Table 20. There were no significant differences in the epididymal adipose tissues weights in the $F_{1}$ generation, but there were significant differences in the other three generations. Only in the $F_{3}$ generation was the epididymal tissue weight of the control animals sfonificantly higher $(P<0.05)$ than the values of animals on the 
Effect of feeding each experimental diet on spleen weights of adult rats for 4 generations 1

\begin{tabular}{|c|c|c|c|c|c|c|c|c|}
\hline \multirow[t]{2}{*}{ Generation } & \multicolumn{2}{|c|}{ Control } & \multicolumn{2}{|c|}{ 1,3-Butylene Glycol } & \multicolumn{2}{|c|}{$\begin{array}{l}\text { 1,3-Butylene Glycol } \\
\text { Mono-Oleate }\end{array}$} & \multicolumn{2}{|c|}{$\begin{array}{l}\text { 1, 3-Butylene Glycol } \\
\text { Mono-Stearate }\end{array}$} \\
\hline & $\begin{array}{l}\text { No. } \\
\text { rats }\end{array}$ & $\begin{array}{l}\% \text { Body } \\
\text { wt }\end{array}$ & $\begin{array}{l}\text { No. } \\
\text { rats }\end{array}$ & $\begin{array}{l}\% \text { Body } \\
\text { wt }\end{array}$ & $\begin{array}{l}\text { No. } \\
\text { rats }\end{array}$ & $\begin{array}{l}\% \text { Body } \\
\text { wt }\end{array}$ & $\begin{array}{l}\text { No. } \\
\text { rats }\end{array}$ & $\begin{array}{c}\% \text { Body } \\
\text { wt }\end{array}$ \\
\hline \multicolumn{9}{|c|}{ Males } \\
\hline $\begin{array}{l}F_{0} \\
F_{1} \\
F_{2} \\
F_{3}\end{array}$ & $\begin{array}{l}2 \\
5 \\
5 \\
4\end{array}$ & $\begin{array}{l}0.15 \pm 0.1^{a^{2}} \\
0.10 \pm 0.0^{a} \\
0.10 \pm 0.0^{a} \\
0.13 \pm 0.0^{a}\end{array}$ & $\begin{array}{r}2 \\
5 \\
5 \\
16\end{array}$ & $\begin{array}{l}0.20 \pm 0.0^{\mathrm{a}} \\
0.20 \pm 0.0^{\mathrm{a}} \\
0.14 \pm 0.0^{\mathrm{b}} \\
0.19 \pm 0.0^{\mathrm{a}}\end{array}$ & $\begin{array}{l}2 \\
5 \\
5 \\
--\end{array}$ & $\begin{array}{c}0.20 \pm 0.0^{\mathrm{a}} \\
0.18 \pm 0.0^{\mathrm{a}} \\
0.12 \pm 0.0^{\mathrm{b}} \\
\ldots .-\end{array}$ & $\begin{array}{l}2 \\
4 \\
5 \\
9\end{array}$ & $\begin{array}{l}0.20 \pm 0.0^{\mathrm{a}} \\
0.15 \pm 0.0^{\mathrm{a}} \\
0.16 \pm 0.0^{\mathrm{a}} \\
0.20 \pm 0.0^{\mathrm{a}}\end{array}$ \\
\hline
\end{tabular}

Females

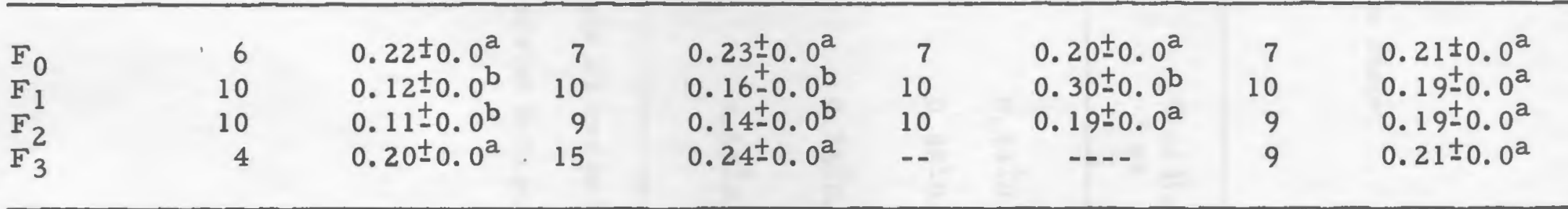

1 Expressed as \% of body weight of animals 24 weeks of age.

Mean $\pm \mathrm{SE}$. A common letter in superscript indicates no significant difference $(\mathrm{P}<0.05)$. 
TABLE 19

Weights of testes of adult $\mathrm{F}_{2}$ generation male rats fed experimental diets ${ }^{1}$

$\begin{array}{llc} & \text { No. } & \% \text { of Body } \\ \text { Diet } & \text { rats } & \text { wt }\end{array}$

Control

1,3-Butylene Glycol

1,3-Butylene Glycol

Mono-Oleate

1,3-Butylene Glycol

Mono-Stearate
5

5

5

5
$0.44 \pm 0.0^{\mathrm{a}^{2}}$

$0.48 \pm 0.0^{a}$

$0.56 \pm 0.0^{\mathrm{a}}$

$0.54 \pm 0.0^{\mathrm{a}}$

1 Expressed as \% of body weight of animals 24 weeks of age.

2 Mean $\pm \mathrm{SE}$. A common letter in superscript indicates no significant difference $(P<0.05)$. 
Epididymal fat tissue weights of adult male rats fed experimental diets by generation ${ }^{1}$

\section{Generation}

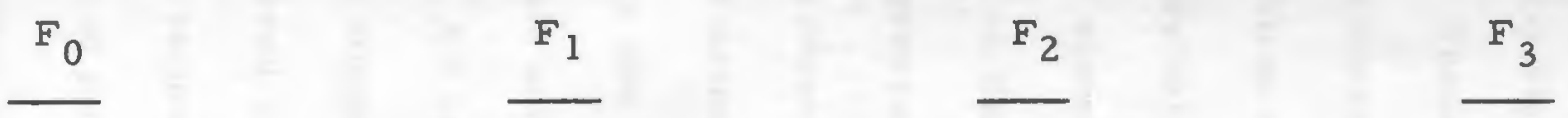

\begin{tabular}{lllllllll} 
Diet & $\begin{array}{l}\text { No. } \\
\text { rats }\end{array}$ & $\begin{array}{c}\% \text { Body } \\
\text { wt }\end{array}$ & $\begin{array}{l}\text { No. } \\
\text { rats }\end{array}$ & $\begin{array}{c}\% \text { Body } \\
\text { wt }\end{array}$ & $\begin{array}{l}\text { No. } \\
\text { rats }\end{array}$ & $\begin{array}{c}\% \text { Body } \\
\text { wt }\end{array}$ & $\begin{array}{l}\text { No. } \\
\text { rats }\end{array}$ & $\begin{array}{c}\% \text { Body } \\
\text { wt }\end{array}$ \\
\hline Control & 2 & $2.7 \pm 0.1^{\mathrm{ab}}$ & 5 & $3.0 \pm 0.1^{\mathrm{a}}$ & 5 & $3.0 \pm 0.1^{\mathrm{a}}$ & 4 & $3.9 \pm 0.2^{\mathrm{a}}$ \\
$\mathrm{BG}^{3}$ & 2 & $3.3 \pm 0.5^{\mathrm{b}}$ & 5 & $3.6 \pm 0.4^{\mathrm{a}}$ & 5 & $3.2 \pm 0.2^{\mathrm{abc}}$ & 16 & $3.1 \pm 0.1^{\mathrm{b}}$ \\
$\mathrm{BGMO}^{4}$ & 2 & $2.0 \pm 0.5^{\mathrm{a}}$ & 5 & $3.5 \pm 0.5^{\mathrm{a}}$ & 5 & $3.6 \pm 0.1^{\mathrm{c}}$ &.- & $-\ldots$ \\
$\mathrm{BGMS}^{5}$ & 2 & $2.5 \pm 0.1^{\mathrm{ab}}$ & 4 & $3.3 \pm 0.1^{\mathrm{a}}$ & 5 & $3.1 \pm 0.1^{\mathrm{ab}}$ & 9 & $3.3 \pm 0.1^{\mathrm{b}}$ \\
\hline
\end{tabular}

1 Expressed as \% of body weight of animals 24 weeks of age.

2 Mean $\pm \mathrm{SE}$. A common letter in superscript indicates no significant difference

$3(\mathrm{P}<0.05)$.

3 1,3-Butylene Glycol.

4 1, 3-Butylene Glycol Mono-Oleate.

5 1,3-Butylene Glycol Mono-Stearate. 
experimental diets. In the $F_{1}$ and $F_{2}$ generations, the males on the $B G$ and $B G M O$ diets had epididymal tis sue weights that were numerically but not significantly higher than those of the animals on the control and BGMS diets. These observations do not completely agree with the findings of Mehlman et al. (34) and Stoewsand et al. (53) who found that the addition of BG to the diets of rats resulted in a significant decrease in epididymal tis sue weights.

Table 21 shows that feeding each experimental diet had little or no effect on the weights of the epididymal fat pad tis sue from the $F_{0}$ to the $F_{3}$ generation. In all but the $B G$ group the epididymal tissue weights increased slightly with succeeding generations.

The conclusion drawn from these observations is that the experimental diets had little effect on the organ weights of four generations of male and female rats maintained on these diets until 24 weeks of age. All organ weights generally remained within normal limits and did not suggest any toxic phenomenon. However, two aberrations occurred which cannot be explained. These are the two sfignificantly high values for the weights of the kidneys and spleen in the $F_{1}$ generation of females fed the diet containing BGMO. An error could have been made in the weighing of these organs, but this was unlikely as the records indicate that all the weights of these organs were consistently high. Some relationship between the abnormal weights and poor reproduction results might be indicated. This is 
Effect of feeding each experimental diet on epididymal fat tissue weights of adult male rats for 4 generations 1

\begin{tabular}{|c|c|c|c|c|c|c|c|c|}
\hline \multirow[t]{2}{*}{ Generation } & \multicolumn{2}{|c|}{ Control } & \multicolumn{2}{|c|}{ 1,3-Butylene Glycol } & \multicolumn{2}{|c|}{$\begin{array}{l}\text { 1,3-Butylene Glycol } \\
\text { Mono-Oleate }\end{array}$} & \multicolumn{2}{|c|}{$\begin{array}{c}\text { 1, 3-Butylene Glycol } \\
\text { Mono-Stearate }\end{array}$} \\
\hline & $\begin{array}{l}\text { No. } \\
\text { rats }\end{array}$ & $\begin{array}{l}\% \text { Body } \\
\text { wt }\end{array}$ & $\begin{array}{l}\text { No. } \\
\text { rats }\end{array}$ & $\begin{array}{l}\% \text { Body } \\
\text { wt }\end{array}$ & $\begin{array}{l}\text { No. } \\
\text { rats }\end{array}$ & $\begin{array}{l}\% \text { Body } \\
\text { wt }\end{array}$ & $\begin{array}{l}\text { No. } \\
\text { rats }\end{array}$ & $\begin{array}{l}\% \text { Body } \\
\text { wt }\end{array}$ \\
\hline$F_{0}$ & 2 & $2.7 \pm 0.1^{\mathrm{a}^{2}}$ & 2 & $3.3 \pm 0.5^{\mathrm{a}}$ & 2 & $2.0 \pm 0.5^{a}$ & 2 & $2.5 \pm 0.1^{\mathrm{a}}$ \\
\hline$F_{1}$ & 5 & $3.0 \pm 1.4^{a}$ & 5 & $3.6 \pm 0.4^{\mathrm{a}}$ & 5 & $3.5 \pm 0.5^{b}$ & 4 & $3.3 \pm 0.1^{\mathrm{b}}$ \\
\hline$F_{2}$ & 5 & $3.0 \pm 0.1^{\mathrm{a}}$ & 5 & $3.2 \pm 0.2^{a}$ & 5 & $3.6 \pm 0.1^{\mathrm{b}}$ & 5 & $3.1 \pm 0.1^{\mathrm{b}}$ \\
\hline $\mathrm{F}_{3}$ & 4 & $3.9 \pm 0.2^{\mathrm{b}}$ & 16 & $3.1 \pm 0.1^{a}$ & - & $-\cdots$ & 9 & $3.3 \pm 0.1^{b}$ \\
\hline
\end{tabular}

1 Expressed as \% of body weight of animals 24 weeks of age.

2 Mean $\pm \mathrm{SE}$. A common letter in superscript indicates no significant difference $(P<0.05)$. 
doubtful, however, as this particular $F_{1}$ generation had a good reproductive performance whereas the $F_{2}$ generation with normal values for the same organs had a poor reproductive performance.

\section{Gross Pathology and His topathology}

At terminal necropsy all animals and organs were examined carefully for any gross pathology. In four generations of rats, including the second litters of the $\mathrm{F}_{2}$ animals, obvious obesity was noted in 12 control animals, seven BG animals, three BGMO animals and two BGMS animals. While some BGMS animals appeared lean, no evidence of poor nutrition was found in any of the animals. The gross pethological findings in the four generations of animals in the four diet groups are as follows: control group, one necrotic liver and one constriction of the spleen; BG group, one case of gastric ulcers and one adhesion of the spleen; BGMO group, one ovarian cyst; BGMS group, one groin tumor that had regressed, one fat pad tumor, one pancreatic tumor, one bladder infection with stones and one pale yellow pigmented fatty-appearing liver. The teeth of all the animals were sound and normal in appearance and there was no evidence of atherosclerosis in the abdominal aortas. In the 24 -week-old animals, lung congestion was distributed equally among all dietary groups. It can be concluded from the necropsies performed on a total of 230 animals that the overall incidence of gross pathological observations (4. 3\%) was incidental and unrelated to the administration of the test 
compounds.

Microscopic examination of tissue sections of liver, spleen, heart, aorta, testes, kidneys and adrenals of the $F_{2}$ generation of animals revealed that all tissues were within normal limits. Any changes observed were those associated with normal processes of aging in the rat. Using the control animals as a point of reference, frozen liver sections were also stained with oil-red-O to reveal lipid accumulation. This procedure revealed a slight increase in lipid accumulation in the livers of the BG males and BGMS females and a sharp increase in lipid accumulation in the livers of the BGMS males. Although the pathologist believed that the stainable lipid was without thologic significance, and close examination of the paraffin sections of the livers of the BGMS males failed to turn up lipid damage, further studies should be made regarding the effect of BGMS on the lipid content of rat livers. Otherwise, on the basis of these observations, none of the synthetic test compounds fed to the animals appeared to have significant adverse effects on any of the tissues examined. The complete histopathology report is given in the Appendix on pages 88 to 93 .

These findings which appear to confirm the evidence of low chronic toxicity for 1,3-Butylene Glycol are in agreement with the findings of Dymsza and Stoewsand (15) when rats were fed a $20 \%$ dietary level of BG for 476 days. They are also in agreement with the findings of Scala and Paynter (47) based on results with rats fed 
a $10 \%$ dietary level of $B G$ for two years. No studies on the toxicity of 1,3-Butylene Glycol Mono-Oleate or 1,3-Butylene Glycol Mono-Stearate were found in the literature for comparison.

Mortality

The incidence of mortality between weaning at 21 days of age and termination at 24 weeks of age was extremely low in four generations of rats, including the second litters of the $F_{2}$ animals. There were no mortalities in the control group. In the BG group, the only two deaths recorded were those of an eight-week old male who was stunted in growth and an adult female rat who had urolithiasis. The three mortalities in the BGMO group were young seven-week old animals from the same litter who died from no apparent cause. The greater number of mortalities occurred in the BGMS group. Four young animals died when seven weeks old, three from no apparent cause and the fourth apparently from cystitis. Of the two adult males who died, one had a kidney tumor and the other had nephritis.

\section{Clinical Chemistry}

Blood serum clinical chemistry indices for the $\mathrm{F}_{2}$ generation of male and female rats are summarized in Table 22. It was not possible to obtain consistent clinical values for rats in the lite rature because of variations due to strain, age, sex, diet and method of 
TABLE 22

Clinical chemistry indices of the blood serum of adult $\mathrm{F}_{2}$ animals ${ }^{1}$

\begin{tabular}{|c|c|c|c|c|c|c|}
\hline Diet & $\begin{array}{l}\text { No. } \\
\text { rats }\end{array}$ & $\begin{array}{c}\text { Glucose } \\
\mathrm{mg} \%\end{array}$ & $\begin{array}{c}\text { Total protein } \\
\mathbf{g} \%\end{array}$ & $\begin{array}{c}\text { Albumin } \\
\mathrm{g} \%\end{array}$ & $\begin{array}{l}\text { Globulin } \\
\text { g\% }\end{array}$ & $\begin{array}{l}\mathrm{A} / \mathrm{G} \\
\text { ratio }\end{array}$ \\
\hline \multicolumn{7}{|c|}{ Males } \\
\hline Control & 5 & $156.0 \pm 11.2^{a^{2}}$ & $7.9 \pm 0.1^{a}$ & $3.6 \pm 0.2^{a}$ & $4.3 \pm 0.1^{a}$ & $0.8 \pm 0.1^{a}$ \\
\hline$B G^{3}$ & 5 & $142.0 \pm 12.8^{a}$ & $6.3 \pm 0.5^{b c}$ & $3.1 \pm 0.4^{a}$ & $3.2^{+}-0.1^{b}$ & $1.0 \pm 0.2^{\mathrm{a}}$ \\
\hline $\mathrm{BGMO}^{4}$ & 5 & $142.0 \pm 3.8^{a}$ & $7.0 \pm 0.1^{\mathrm{ac}}$ & $3.5^{ \pm}-0.1^{a}$ & $3.3 \pm 0.2^{\mathrm{b}}$ & $1.0 \pm 0.1^{a}$ \\
\hline $\mathrm{BGMS}^{5}$ & 5 & $134.0 \pm 8.1^{\mathrm{a}}$ & $6.0 \pm 0.4^{\mathrm{b}}$ & $2.9 \pm 0.1^{a}$ & $3.0 \pm 0.3^{b}$ & $1.0 \pm 0.1^{a}$ \\
\hline \multicolumn{7}{|c|}{ Females } \\
\hline Control & 10 & $128.0 \pm 4.6^{\mathrm{ac}}$ & $9.2^{ \pm 0.4^{a}}$ & $5.5 \pm 0.3^{a}$ & $3.7 \pm 0.1^{a}$ & $1.4^{ \pm} 0.1^{a}$ \\
\hline$B G$ & 8 & $101.9^{ \pm} 6.3^{b}$ & $6.1 \pm 0.3^{b d}$ & $2.7^{ \pm} 0.3^{b}$ & $3.6 \pm 0.1^{a b}$ & $0.9 \pm 0.1^{b}$ \\
\hline BGMO & 10 & $133.0 \pm 4.5^{a}$ & $7.6 \pm 0.1^{c}$ & $4.2 \pm 0.1^{a}$ & $3.3 \pm 0.3^{b c}$ & $1.2 \pm 0.0^{a}$ \\
\hline BGMS & 9 & $114.4 \pm 9.1^{\mathrm{bc}}$ & $5.7 \pm 0.3^{d}$ & $2.6 \pm 0.1^{b}$ & $3.1 \pm 0.2^{c d}$ & $0.8 \pm 0.1^{b}$ \\
\hline
\end{tabular}

1 Animals were 24 weeks of age.

2 Mean \pm SE. A common letter in superscript indicates no significant difference $(P<0.05)$.

3 1,3-Butylene Glycol.

4 1,3-Butylene Glycol Mono-Oleate.

5 1,3-Butylene Glycol Mono-Stearate. 
"TABLE 22, Cont'd"

\begin{tabular}{|c|c|c|c|c|c|c|}
\hline Diet & $\begin{array}{l}\text { No. } \\
\text { rats }\end{array}$ & $\begin{array}{l}\text { Uric acid } \\
\text { mg\% }\end{array}$ & $\begin{array}{c}\text { Urea nitrogen } \\
\text { mg\% }\end{array}$ & $\begin{array}{c}\text { Calcium } \\
\mathrm{mg} \%\end{array}$ & $\begin{array}{c}\text { Inorganic } \\
\text { phosphorus } \\
\text { mg\% }\end{array}$ & $\begin{array}{c}\text { Bilirubir } \\
\text { mg\% }\end{array}$ \\
\hline \multicolumn{7}{|c|}{ Males } \\
\hline Control & 5 & $2.0 \pm 0.2 \mathrm{abl}$ & $17.8 \pm 1.2^{\mathrm{a}}$ & $10.8 \pm 0.1^{a}$ & $5.5 \pm 0.1^{a}$ & $1.1 \pm 0.2^{a}$ \\
\hline $\mathrm{BG}^{2}$ & 5 & $1.6 \pm 0.2^{\mathrm{a}}$ & $12.2^{ \pm}-0.7^{b c}$ & $9.2 \pm 0.7^{b}$ & $5.9 \pm 0.4^{\mathrm{ab}}$ & $1.5 \pm 0.6^{a}$ \\
\hline $\mathrm{BGMO}^{3}$ & 5 & $1.9 \pm 0.0^{\mathrm{ab}}$ & $14.0 \pm 0.7^{\mathrm{cd}}$ & $10.7 \pm 0.1^{a}$ & $6.2 \pm 0.2^{\mathrm{ab}}$ & $0.4 \pm 0.0^{\mathrm{a}}$ \\
\hline $\mathrm{BGMS}^{4}$ & 5 & $2.2^{ \pm} \pm 0.1^{b}$ & $15.0 \pm 1.4^{d}$ & $8.0 \pm 0.3^{c}$ & $6.5 \pm 0.3^{b}$ & $0.4 \pm 0.1^{a}$ \\
\hline \multicolumn{7}{|c|}{ Females } \\
\hline Control & 10 & $1.7 \pm 0.1^{2}$ & $14.4^{ \pm} \pm 0.5^{a}$ & $11.1 \pm 0.2^{2}$ & $5.6 \pm 0.2^{a}$ & $3.1 \pm 0.6^{a}$ \\
\hline BG & 8 & $1.5 \pm 0.2^{\mathrm{a}}$ & $11.8 \pm 1.1^{b}$ & 8. $4^{ \pm 0 .} 3^{b}$ & $4.5 \pm 0.3^{b}$ & $1.2 \pm 0.3^{b}$ \\
\hline BGMO & 10 & $2.1 \pm 0.1^{b}$ & $14.8^{ \pm}-0.5^{a}$ & $10.8 \pm 0.1^{\mathrm{a}}$ & $5.7 \pm 0.1^{a}$ & $0.5 \pm 0.0^{b}$ \\
\hline BGMS & 9 & $2.2^{ \pm} 0.2^{b}$ & $19.2 \pm 0.8^{c}$ & $7.6 \pm 0.3^{b}$ & $5.7 \pm 0.2^{\mathrm{a}}$ & $0.4 \pm 0.0^{\mathrm{b}}$ \\
\hline
\end{tabular}


"TABLE 22, Cont'd"

\begin{tabular}{|c|c|c|c|c|c|c|}
\hline Diet & $\begin{array}{l}\text { No. } \\
\text { rats }\end{array}$ & $\begin{array}{c}\text { Cholesterol } \\
\text { mg\% }\end{array}$ & $\begin{array}{c}\text { Triglycerides } \\
\text { mg\% }\end{array}$ & $\begin{array}{l}\text { Lactic } \\
\text { dehydrogenase } \\
\qquad \text { WU }\end{array}$ & $\begin{array}{c}\text { Alkaline } \\
\text { phosphatase } \\
\text { KAU }\end{array}$ & $\begin{array}{c}\text { SGOT }^{1} \\
\mathrm{KU}\end{array}$ \\
\hline & & & Males & & & \\
\hline Control & 5 & $153.0 \pm 12.7 \mathrm{abc}^{2}$ & $125.0 \pm 9.5^{\mathrm{a}}$ & $666.0 \pm 23.6^{a}$ & $14.4 \pm 7.5^{a}$ & $251.0 \pm 29.7^{a}$ \\
\hline$B G^{3}$ & 5 & $121.0 \pm 13.3^{a}$ & $151.0 \pm 1.3^{\mathrm{ab}}$ & $440.0 \pm 126.9^{b}$ & $7.0 \pm 1.7^{\mathrm{b}}$ & $176.0^{ \pm}-29.1^{\mathrm{b}}$ \\
\hline $\mathrm{BGMO}^{4}$ & 5 & $161.2 \pm 13.0^{\mathrm{bc}}$ & $114.0 \pm 3.4^{\mathrm{ac}}$ & $666.0 \pm 27.1^{a}$ & $17.6 \pm 2.3^{a}$ & $276.0 \pm 11.7^{a}$ \\
\hline \multirow[t]{2}{*}{$\mathrm{BGMS}^{5}$} & 5 & $130.0 \pm 13.0^{a}$ & $109.8^{ \pm} 5.2^{\mathrm{ac}}$ & $608.0 \pm 77.9^{a b}$ & $12.8 \pm 1.8^{\mathrm{a}}$ & $258.0 \pm 40.4^{a}$ \\
\hline & & & Females & & & \\
\hline Control & $10^{\circ}$ & $167.0 \pm 9.0^{\mathrm{a}}$ & $145.9 \pm 17.0^{a}$ & $669.0 \pm 44.3^{a}$ & $18.0 \pm 1.7^{a}$ & $194.0 \pm 13.7^{a b}$ \\
\hline $\mathrm{BG}$ & 8 & $101.3 \pm 9.0^{b}$ & $134.3 \pm 3.2^{\mathrm{ac}}$ & $294.4^{ \pm} 96.9^{b}$ & $3.9 \pm 0.7^{b}$ & $165.0 \pm 11.9^{b}$ \\
\hline BGMO & 10 & $169.1 \pm 4.8^{a}$ & $107.9 \pm 6.1^{b}$ & $656.0 \pm 21.3^{a}$ & $15.1 \pm 1.5^{a}$ & $208.0 \pm 9.0^{\mathrm{ab}}$ \\
\hline BGMS & 9 & $114.4^{ \pm} 5.8^{\mathrm{b}}$ & $110.7^{ \pm} 1.3^{\mathrm{bc}}$ & $375.6 \pm 72.4^{b}$ & $3.6^{+}-7.5^{\mathrm{b}}$ & $221.0 \pm 17.8^{a}$ \\
\hline
\end{tabular}

1 Serum glutamic oxalacetic transaminase.

2 Mean \pm SE. A common letter in superscript indicates no significant difference (P< 0.05$)$.

3 1,3-Butylene Glycol.

4,3-Butylene Glycol Mono-Oleate.

5 1,3-Butylene Glycol Mono-Stearate. 
detemination. A chart showing normal values and ranges for 300 gram adult rats maintained at the Charles River Laboratories is given in the Appendix on page 99.

\section{Glucose}

Glucose values which ranged from 101.9-156.0 mg\% were slightly higher than the values of $65.0-110.0 \mathrm{mg} \%$ given by the Charles River Laboratories, but are similar to the values of 112. $0-176.0 \mathrm{mg} \%$ reported by Kozma et al. (32) and the values of 129. 0-134. $0 \mathrm{mg} \%$ for control animals reported by Giri et al (26). There were no significant differences between the values for the males on any of the diets. However, there were some significant differences between the values for the females, but these values are within an acceptable normal range.

Total Serum Protein, Albumin, Globulin and A/G Ratio

Total blood protein values ranged from 5.7-9.2 $\mathrm{g} \%$ and appeared normal when compared to the values of $6.0-8.0 \mathrm{~g} \%$ reported by Charles River Laboratories and the values of 4.4-10.2 $\mathrm{g} \%$ reported by Burns and deLannoy (12). The albumin values, which ranged from 2.6-4.2 $\mathrm{g} \%$ are also within normal limits when compared to the values of $3.5-5.0 \mathrm{~g} \%$ reported in the Charles River Study and the values of 2.3-5. $4 \mathrm{~g} \%$ reported by Burns and deLannoy (12). Globulin values ranged from $3 \cdot 0-4.3 \mathrm{~g} \%$ and were higher than the values of 
1.2-3. $2 \mathrm{~g} \%$ reported by the Charles River Laboratories. Since the thobulin values were high the $A / G$ ratio of $0.8-1.4$ was subsequently slightly lower than the ratio of $1.1-2.2$ reported in the Charles River Study.

There were some significant differences in these four clinical values in the diet groups of both the male and female rats. However, none of these differences are considered to be of pathological importance. The reason for this conclusion is that the high values for total serum protein, albumin and globulin obtained in the control groups of male and female rats were not always slonificantly different from the values obtained in the other diet groups. Furthermore, the $A / G$ ratio remained fairly consistent for all animals.

Uric Acid and Urea Nitrogen (BUN)

The values for uric acid ranged from $1.5-2.0 \mathrm{mg} \%$ which are lower than the values of $2.5-8.0 \mathrm{mg} \%$ reported in the Charles River Study. The blood urea nitrogen ranged from 11.8-19.2 mg\% which is in agreement with the Charles River values of $10.0-20.0 \mathrm{mg} \%$. The low concentration of uric acid does not appear to be of thological importance since this was fairly uniform with respect to diet and sex. However, there were highly significant differences $(P<0.05)$ in the values for blood urea nitrogen. In the males a sforificantly higher BUN value was observed for the control group 
while in the females a significantly higher BUN was observed in the BGMS group. Nevertheless, both of these values for blood urea nitrogen are within the higher limits of the acceptable normal range.

Calcium and Inorganic Phosphorus

The range of values for calcium, $7.6-11.1 \mathrm{mg} \%$, are normal when compared with the values of $8.5-11.0 \mathrm{mg} \%$ in the Charles River Study, with the exception of two low values observed in the BGMS group of animals. The value of $7.6 \mathrm{mg} \%$ for the females and that of $8.1 \mathrm{mg} \%$ for the males were significantly lower than the values for the female and male rats in the control and BGMO groups. They were not, however, significantly lower than the values for the animals in the BG group. While the values for inorganic phosphorus, which ranged from 4.5-6.5 mg\%, were considerably higher than the values of $2.5-4.5 \mathrm{mg} \%$ reported in the Charles River Study, they do agree with the random-sexed values of $4.0-8.7 \mathrm{mg} \%$ observed by Burns and delannoy (12). There were very few significant differences in the organic phosphorus values between the sexes or diet groups.

\section{Bilirubin}

In the control group of females, the bilirubin concentration of $3.1 \mathrm{mg} \%$ was significantly higher than the other male or female 
values. This high value was in part due to the inclusion of a value of $8.0 \mathrm{mg} \%$ for one female in the control group. This value was not excluded as this female produced a litter and appeared healthy. The other values which ranged from $0.4-1.5 \mathrm{mg} \%$ appear to be within normal limits although they are slightly higher than the Charles River Laboratory values of $0.2-1.0 \mathrm{mg} \%$.

\section{Cholesterol}

While there were some differences in cholesterol values with respect to diet and sex, these values which ranged from 101.3-169. $1 \mathrm{mg} \%$ are considerably lower than the normal values of 150.0-300.0 mg\% reported by the Charles River Laboratories and more similar to the mean value of $101.3 \mathrm{mg} \%$ for control animals reported by Berger (5). Both the male and female rats fed the BGMO diet which contained the mono-unsaturated fatty acid, oleic acid, had the highest cholesterol levels. In contrast, the BGMS diet which contained the saturated fatty acid, stearic acid, produced rather low cholesterol levels. The lowest cholesterol levels were found in the male and female animals fed the BG diet. In spite of these differences, all the values are within the normal range for rats.

\section{Iiglycerides}

The values for triglycerides which ranged from 107. 9-151.0 $\mathrm{mg} \%$ are in agreement with the normal values of 
74. $0-172.0 \mathrm{mg} \%$ reported by Eggste in (18), whose methodology was used in performing the tests. Although the differences were not always slgnificant, all the animals fed the control and BG diets had the highest triglyceride values, whereas the animals fed the BGMO and BGMS diets had the lowest values. This showed that there was little correlation with the cholesterol values mentioned previously. Since rats are very resistent to atherosclerosis as observed by Bonner et al. (6), the low triglyceride and cholesterol values are normal in rats in which hyperlipemia has not been produced by the addition of hyperlipemic agents such as cholesterol. It is, therefore, concluded that BG, BGMO and BGMS are not hyperlipemic agents.

\section{Lactic Dehydrogenase (LDH)}

There was a wide range in the values obtained for $L D H$. In the males, these values ranged from 440-660 WU, and in the females the variation was from 294-669 WU. These values are considerably higher than the normal values of 30-130 WU given in the Charles River Study, but there were few significant differences within the male and female groups of animals fed the various diets. While LDH activity is used clinically as an indicator of nephron damage and hyperlipemia, there was no evidence of kidney disease in the histopathology and the cholesterol and triglyceride values were normal. 
Alkaline Phosphatase

The range of values for alkaline phosphatase activity, 3.6-18.0 KAU, were similar to the values of 4.0-17.0 KAU for rats mintained at the Charles River Laboratories. The males fed the diet containing $B G$ had a significantly lower value $(P<0.05)$ than the males fed the other diets. With respect to the females, the rats fed the diet containing BGMS had the lowest value while the rats fed the control diet had the highest value. There were no significant differences between the control and BGMO females; nor were there shenificant differences between the BG and BGMS females.

\section{Serum Glutamic Oxalacetic Transaminase (SGOT)}

The SGOT values which ranged from 176-251 KU were much higher than the 10-40 KU given in the Charles River Study. The mean SGOT value of $124 \mathrm{U}$ reported by Grabrieli and Orfanos et al. (28) and the mean value of 126 SFU reported by Kozma et al. (32) are more similar to the values obtained in this experiment, but these observations cannot be corroborated as the enzyme assays were not identical. In the male rats, the only significant difference encountered was a lower SGOT value for rats fed $\mathrm{BG}$. In the females, the only difference was that the rats fed BG had values significantly lower than the rats fed the control or BGMS diets. It is unlikely that any of these values are related to myocardial infarctions or liver malfunction, as the histopathologic examination of these tissue sections was normal. 
Pematology

The hematologic indices for the adult $\mathrm{F}_{3}$ generation of male and female rats are summarized in Table 23. The values for packed cell volume (hematocrit) which ranged from $54.0-59.6 \%$ were statistically uniform with respect to diet and sex. Although these values are higher than the values of $37.0-49.0 \%$ reported by Burns and deLannoy (12) and the mean value of $45.8 \%$ reported by Gardner (22), they are similar to the mean value of $53.8 \%$ for control animals in a study reported by Adams et al. (1). The percentage of neutrophils which ranged from 18.0-32.5\% was slightly lower, and the percentage of lymphocytes which ranged from 67.5-83.0\% was slightly higher, than the values reported by Kozma et al. (32), but they do agree with the values obtained by Adams et al. (1). No values were given in the Charles River Study for comparison.

While the hematologic values obtained for the animals on the test diets appear within the normal range and are comparible with control values, the data is incomplete because no animals fed BGMO survived. Furthermore, it was not possible to obtain the same information for the $F_{2}$ generation of animals. 
TABLE 23

Hematologic indices of adult $F_{3}$ animals ${ }^{1}$

No.

Diet

rats $^{2}$ Neutrophils Lymphocytes Hematocrit

$\%$

$\%$

$\%$

Males

Control

$4 \quad 32.5 \pm 6.8^{\mathrm{a}^{3}}$

$67.5 \pm 6.8^{a}$

$54.0 \pm 1.4^{\mathrm{a}}$

1,3-Butylene Glycol 16

18. $9 \pm 2.9^{b}$

$79.8^{+}-2.8^{b}$

$57.0 \pm 2.2^{a}$

1,3-Butylene Glycol Mono-Stearate

$9 \quad 23.3 \pm 2.0^{\mathrm{ab}}$

$76.7^{+}-2.0^{\mathrm{ab}}$

$56.8 \pm 2.5^{a}$

Females

Control

$4 \quad 17.0 \pm 6.7^{a}$

83. $0 \pm 6.6^{a}$

55. $0^{ \pm}, 8^{a}$

1,3-Butylene Glycol

9

18. $0 \pm 3.1^{a}$

81. $7 \pm 3.1^{\mathrm{a}}$

57. $9 \pm 3.3^{a}$

1,3-Butylene Glycol

Mono-Stearate

$9 \quad 18.2 \pm 3.2^{\mathrm{a}}$

$81.8 \pm 3.2^{a}$

$59.6 \pm 2.7^{\mathrm{a}}$

1 No animals fed 1,3-Butylene Glycol Mono-Oleate survived in the $\mathrm{F}_{3}$ generation.

2 Rats were 24 weeks of age.

3 Mean \pm SE. A common letter in superscript indicates no significant difference $(P<0.05)$. 


\section{SUMMARY AND CONCLUSIONS}

In this reproduction and development study, four generations of rats were fed either a semi-purified control diet or three similar diets, in which part of the carbohydrates were replaced by a $20 \%$ dietary level of synthetic energy sources in the form of 1,3-Butylene Glycol (BG), 1,3-Butylene Glycol Mono-Oleate (BGMO) and 1,3-Butylene Glycol Mono-Stearate (BGMS). The results can be summarized as follows:

1. In most generations, greater fertility indices, more pups born alive and larger survival rates were obtained in the $B G$ and BGMS experimental diet groups.

2. The diets had no effect on average litter size until

the $\mathrm{F}_{3(2)}$ generation, when no pups in the BGMO group were born alive and no litters were produced in the control group.

3. Average birth weights of animals fed the control diet were higher in all generations, but only significantly higher $(P<0.05)$ in the $F_{2}$ generation. There were few significant differences in birth weights between the other diet groups.

4. There were no significant differences in average weaning weights in any generation except in the $F_{2}$ generation where the control group had a significantly higher weaning weight $(P<0.05)$, 
and the BGMS group had a significantly lower weaning weight than all other groups.

5. Litter size, birth and weaning weights generally declined for all diet groups with succeeding generations, but the decline was not significant in most cases.

6. Weight gains of young litters from four to eight weeks of age were highest in the control group and lowest in the BGMS diet group. However, these differences were only significant in the $\mathrm{F}_{2}$ generation.

7. The animals fed the control diet consumed significantly more food in the first two generations. This diet furnished the least amount of calories per gram and, presumably, was more palatable.

8. There were no significant differences in the food efficiencies in all diet groups indicating that the three test compounds were well utilized.

9. Four to eight week weight gains and food consumption for all diet groups increased but not always significantly with succeeding generations. Food efficiencies remained essentially the same except for some fluctuations in the BGMS group.

10. Terminal 24-week body weights of four generations of male and female rats were generally higher in the control and BG groups, with few significant group differences. Terminal body 
weights were generally lower in the BGMO and BGMS groups of male and females with few significant differences between these groups or between the BG groups of male and female rats.

11. The experimental diets had little effect in four generations on terminal 24-week adult organ weights expressed as percentage of body weight.

12. There were few significant differences in epididymal adipose tissue weights in four generations of male rats fed the various diets.

13. Gross pathological observations revealed a low incidence of lesions or tumors, with most of these occurring in the BGMS diet group.

14. Histopathological evaluation of the tissues of $F_{2}$ generation animals showed that the diets had no adverse effect on any tissues. This indicated that the compounds are low in toxicity. However, there is some indication for need of further study regarding the compound, BGMS.

15. Mortality was extremely low throughout the entire experiment with a few more mortalities occurring in the BGMS group than in the other diet groups.

16. Blood se rum clinical values were generally normal as far as could be determined by comparis on of normal rat values from other studies. Any aberrations found in the blood serum clinical 
tests are not considered to be of pathological importance. While lipid cumulation was noted on fat staining in liver section of the male rats fed BGMS, there were no significant differences observed in the SGOT, LDH, cholesterol and triglyceride values in the serum of either the male or female rats who were fed this particular diet.

17. Hematological findings for the $F_{3}$ generation were generally normal and unrelated to the dietary treatments.

This four-generation study revealed much more information concerning the safety of these compounds than just a growth study alone. While the growth study phase showed all diets to be well utilized even though there were some body weight differences, the reproduction study revealed that the control and BGMO diets could not adequately support reproduction and lactation in the third generation. As compared with the controls, the rats fed BG and BGMS diets had superior reproduction and lactation performances. Rats fed BGMO did not perform even as well as the controls, since no pups were weaned from this diet group in the fourth generation. It is not known what caused the poor reproduction and survival results in the BGMO and control diet groups. Speculation can only be made that these two semi-purified diets possibly were lacking in some essential factor which somehow was present in the BG and BGMS diets. The absence of this factor, through endocrine or other pathways, perhaps caused impregnation or nursing failures 
or in some way adversely influenced fetal and neo-natal development. Othe rwise, there was no evidence that either of these two diets were toxic, as the animals fed the se diets had a low mortality rate, low incidence of pathological lesions, essentially normal clinical values and absence of disease when their tissues were examined microscopically.

By all parameters, BG appeared to be low in toxicity when fed at a dietary level of $20 \%$ to rats. In contrast with the reproductive failures obtained in rats fed the control and BGMO diets, this BG compound could support moderate levels of reproduction in the third generation, and pups also survived in the fourth generation. Although the reproduction and lactation performances of the animals fed BGMS were much better than those of animals fed BGMO, it is believed that careful further study is necessary regarding the safety of BGMS. From the results obtained in this study, it is extremely difficult to evaluate the safety of the BGMO compound. While gross thological, clinical and histopathological observations indicated that the animals fed BGMO were healthy in all respects, nevertheless, these animals, like the controls, did not perform well in regard to reproduction.

Several suggestions can be made with respect to further studies concerning the control diet and the diets containing the BGMO and BGMS compounds. A replicate experiment should be undertaken 
using the same control, BGMO and BGMS diets, only modified by the use of three additional diets. The three new diets should be a second control diet; a common laboratory animal chow ration; a second BGMO diet, containing a specific increase in vitamin $\mathrm{E}$; and for comparison, a second BGMS diet in which the vitamin E content is decreased by the same amount. Another suggestion would be to conduct a duplicate of the described study using a different strain of rats to observe whether similar results could be obtained. A third suggestion would be to conduct also a longevity study, keeping a reasonable amount of the first litters of each generation for this purpose, and using the second litters of each generation for studying the effects of the diets on keproduction. A fourth suggestion would be to determine the amount of impregnation and fetal absorption which was not determined in this study. 
LITERATURE CITED 


\section{LITERATURE CITED}

1. Adams, S. S., R. G. Bough, E. E. Cliffee, B. Lessel and R. F. Mills 1969 Mean organ weights and mean blood values. Absorption, distribution and toxicity of ibuprofen in dogs and albino rats. Toxicol. Appl. Pharmacol. 15:310.

2. Bergelson, L. D., V. A. Vaver and N. V. Prokozova 1964 New types of neutral lipids. Dobl. Akad. Nauk. USSR 157:122. (Chem. Abs. 61:8559 e, 1965)

3. Bergels on, L. D., V. A. Vaver, N. V. Prokozova, A. N. Ushakov and G. A. Popkova 1966 Diol lipids, 1. Biochim. Biophys. Acta 116:511. (Chem. Abs. 65:4153 d, 1966)

4. Bergelson, L. D. and V. A. Vaver 1966 Structural diversity of lipids and a new approach to the dynamic state of the cell membrane, 2. Zh. Evolyutsionnoi Biokhim. i Fiziol. 2:118. (Chem. Abs. 65:5735 e, 1966)

5. Berger, F. M., J. F. Douglas, G. G. Lu and B. S. Ludwig 1970 Effect of N-phenylpropyl-N-benzyloxy acetamide and of clofibrate on the lipids of normal and hypercholesteremic rats. Proc. Soc. Exp. Biol. Med. 132:293.

6. Bonner, M. J., H. V. Kothari and B. F. Miller 1970 Lysomal enzymes in aortas of species susceptible and resistant to atherosclerosis. Federation Proc.

$29: 444$.

7. Bornmann, G. 1950 Hemolytic action of polyhydric alcohols. Pharmazie 5:423. (Chem. Abs. 45:1251 i, 1951)

8. Bornmann, G. and K. Ritter 1953 Diuretic action of multivalent alcohols. Naunyn-Schmiedebergs Arch. Exp. Pathol. Pharmakol. 219:57. (Chem. Abs. 47:94972 j, 1953)

9. Bornmann, G. 1954 a Physiological properties of glycols and their toxicity, 1. Arzaneimittel-Forsch. 4:643. (Chem. Abs. 49:7131 a, 1955) 
10. Bornmann, G. 1954b Physiological properties of glycols and their toxicity, 2. Arzaneimittel-Forsch. 4:710. (Chem. Abs. 49:7131 a, 1955)

11. Bornmann, G. 1955 Fundamental effects of the glycols and their relation to toxicity, 3. Arzaneimittel-Forsch. 5:38. (Chem. Abs. 49:7131 a, 1955)

12. Burns, K. F. and C. W. deLannoy, Jr. 1966 Compendium of normal blood values of laboratory animals, with indication of variations. 1. Random-sexed populations of small animals. Toxicol. Appl. Pharmacol. 8:429.

13. Davenport, R. F., M. Griffith and A. B. Watts 1967 Utilization of 1,3-butanediol by growing chicks. (Abs.) Poultry Sci. 46:1250.

14. Dube, J. N. 1967 Alimentary aspects of butanediol in rumen fermentation. Arch. Tierernaehr. 17:131. (Chem. Abs. 66:103993 t, 1967)

15. Dymsza, H. A. and G. S. Stoewsand 1965 Data on rats fed $20 \%$ 1,3-butylene glycol for 476 days. U. S. Army Natick Laboratories Notebook No. 4050, issued to J. M. McDonald, April 30, 1965. U. S. Army Natick Laboratories Library.

16. Dymsza, H. A. and G. S. Stoewsand 1966 Data on dogs fed 20\% 1,3-butylene glycol for 343 days. U. S. Army Natick Laboratories Notebook No. 4192, issued to J. M. McDonald, October 18, 1966. U. S. Army Natick Laboratories Library.

17. Dymsza, H. A., G. S. Stoewsand, and S. A. Miller 1967 Metabolizable Energy Content of Unconventional Food Esters. Federation Proc. 26:769.

18. Eggstein, M. 1965 Calculation of the blood serum natural fats as the difference between the esterified fatty acics and lipid fatty acids. Klin. Wochschr. 43:1031. (Chem. Abs. 64:1101 g, 1966)

19. Ershoff, B. H., G. S. Bajwa, J. B. Field and L. A. Bavetta 1969 Comparative effects of purified diets and a natural food stock ration on the tumor incidence of mice exposed to multiple sublethal doses of total-body X-irradiation. Cancer Res. 29:780. 
20. Ferguson, M. M., A. H. Baillie, K. C. Calman, and D. M. Hart 1966 Histochemical distribution of alcohol dehydrogenases in endocrine tissue. Nature 5042:1277.

21. Fischer, L., R. Kopf, A. Loeser and G. Meyer 1949 Chemical composition and the pharmocological effect of glycols, especially 1,3-butylene glycol. Z. Gesante Exp. Med. 115:22. (Chem. Abs. 44:9070 c, 1950)

22. Gardner, M. V. 1947 The blood picture of normal laboratory animals. A review of the literature. J. Franklin Inst. 243:77 (rat).

23. Genevois, L., E. Peynaud and J. Ribereau-Gayon 1948a Action of the medium on the secondary products of the alcoholic fermentation of elliptic yeasts, 1. Compt. Rend. 226:126. (Chem. Abs. 42:3132 f, 1948)

24. Genevois, L., E. Peynaud and J. Ribereau-Gayon 1948b Balance sheet of secondary products from alcoholic fermentation in Bordeaux red wines, 2. Compt. Rend. 226:439. (Chem. Abs. 42:3529 a, 1948)

25. Gessner, P. K., D. V. Parke and R. T. Williams 1960 Detoxication. The metabolism of glycols. Biochem. J. $74: 1$.

26. Giri, S. N., S. A. Peoples and R. L. Mull 1970 Effects of 1,2-propanediol on blood glucose and liver glycogen of young Sprague-Dawley rats. Proc. Soc. Exp. Biol. Med. 133:593.

27. Gobis, L. and A. Pisek 1950 The butylene glycol, acetyl-methylcarbinol and diacetyl content of milk and its derivatives. VIII Cong. Inter. inds. agr. Brussels 4:46. (Chem. Abs. 48:2279 i, 1954)

28. Grabrieli, E. R. and A. Orfanos 1968 Effect of carbon tetrachloride on serum glutamic oxalacetic transaminase is oenzymes in the rat. Proc. Soc. Exp. Biol. Med. 127:766.

29. Husing, E., R. Kopf and A. Loeser 1950 Action of 1,3-butylene glycol on the skin. Fetteu. Seifer 52:45. (Chem. Abs. 44:7999 g, 1950) 
30. Is grig, F. A. and J. J. Ayres 1968 Some behavior effects of two experimental nutrients. Psycopharmacologia $12: 227$.

31. Kersters, K. and J. de Ley 1963 The oxidation of glycols by acetic acid bacteria. Biochim. Biophys. Acta 71:311. (Chem. Abs. 59:915 h, 1963)

32. Kozma, C. K., S. H. Weisbroth, S. L. Stratman and M. Conejeros 1969 Normal Biological values for Long-Evans Rats. Lab. Animal Care 19:746.

33. Loeser, A. 1949 1,3-Butylene glycol. Pharmazie 4:263. (Chem. Abs. 43:8558 b, 1949)

34. Mehlman, M. A., D. G. Therreault, W. Porter, G. S. Stoewsand and H. A. Dymsza 1966 Distribution of lipids in rats fed 1,3-butanediol. J. Nutr. 88:215.

35. Mehlman, M. A. Studies conducted at the Institute for Enzyme Research, University of Wisconsin (unpublished, 1967).

36. Meyer, G. 1951 Comparative experiments on the influence of polyhydric alcohols on reproductive processes. Fette u. Seifer 53:88. (Chem. Abs. 45:9743 d, 1951)

37. Meyer, G. and H. Shurmeyer $1951^{\text {'The action of }}$ 1,3-butylene glycol on the generative processes in rats. Klin. Wochschr. 29:231. (Chem. Abs. 45:8145 d, 1951)

38. Miller, S. A., A. M. Browning and P. Turransky 1965 The metabolism of 1,3 -butanediol in the rat. Federation Proc. 24:439.

39. Miller, S. A. and H. A. Dymsza 1967 Utilization by the rat of 1,3-butanediol as a synthetic source of energy. J. Nutr. 91:79.

40. Opitz, K. 1958a Formation of glucose and glycogen from glycols in vitro. Arch. exp. Pathol. Pharmakol. 223:355. (Chem. Abs. 52:11221 b, 1958)

41. Opitz, K. 1958b Glycogen-forming action of glycols. Arch. exp. Path. Pharmak. 234:448.

(Chem. Abs. 53:1551 b, 1958) 
42. Patel, M. S. and S. P. Mistry 1968 Effect of biotin deficiency on food intake and body and organ weights of male albino Sprague-Dawley rats. Growth 32:175.

43. Patschky, A. 1967 Determination of the alcohol supplement in table wines. Deut. Lebensm. Rundoch. 63:197. (Chem. Abs. 67:98934 p, 1967)

44.

Peters, J. M. 1967 Effects of absolute starvation and re-feeding on organ weights and water contents of albino rats. Growth 31:191.

45. Pleasants, J. R., B. S. Reddy and B. S. Wostmann 1969 Qualitative adequacy of defined chemical diets for successive generations of germ-free mice. Federation Proc. $28: 306$.

46. Rogers, G. R. and A. E. Harper 1965 Rogers-Harper Salt Mix. J. Nutr. 87:267.

47.

Scala, R. A. and O. E. Paynter 1967 Chronic oral toxicity of 1,3-butanediol. Toxicol. Appl. Pharmacol. 10:160.

48. Schubert, R. H. W. and G. Kexel 1964 The butanediol dehydrogenase reaction of some Pseudomonadaceae and vibrios. Zentralbl. Bakteriol. Parasitenk, Infektionskr. Hyg., Abt. 1, Orig. 194:130. (Chem. Abs. 66:355532 q, 1967)

49. Schluึssel, H. 1953 Sparing effect of polyhydric alcohols in nutrition and some remarks on enlarging the basis of our nutrition. Klin. Wochschr. 31:768. (Chem. Abs. 47:11382 c, 1953)

50. Schlüssel, H. 1954 Utilization of multivalent alcohols in nutrition. Naunyn-Schmiedebergs, Arch. exp. Pathol. Pharmakol. 221:67. (Chem. Abs. 48:5315 c, 1954)

51. Smyth, H. F., C. P. Carpenter and C. S. Weil 1951 Range-finding toxicity data: List IV. A. M. A. Archives Indust. Hyg. and Occup. Med. 4:119. 
52. Sprince, H., J. A. Josephs and C. R. Wilpizeski 1966 Neuropharmacological effects of 1,3-butanediol on related congers compared with those of $v$-hydroxy butrate and $v$-butyrolactone. Life Sci. 5:2041.

53. Stoewsand. G. S., H. A. Dymsza, M. A. Mehlman and D. G. Therreault 1965 Influence of 1,3-butanediol on tissue lipids of cold exposed rats. J. Nutr. 87:464.

54.

Stoewsand, G. S. , H. A. Dymsza, M. A. Mehlman, S. M. Swift and D. G. Therreault 1966 Effect of feeding polyhydric alcohols on tissue lipids and the resistance of rats to extreme cold. J. Nutr. 89:414.

55.

Stoewsand, G. S., H. A. Dymsza, M. A. Kilmore and S. M. Swift 1966 Plasma lipid changes in exercised dogs fed 1,3-butanediol. Federation Proc. 25:608.

56.

Stoewsand, G. S. and H. A. Dymsza 1967 Synthetic sources of calories in the diets of rats and dogs. Proc. 7th Int. Congr. Nutr. (Hamburg, 1966), Vol. 5, P. 3. Pergamon Press, 1967.

57.

Vaver, V. A., V. A. Shchennikov and L. D. Bergels on 1967 Diol lipids. Dihydric alcohols in the phospholipids of mammalian tissues. Biokhimiya 32:1027.

(Chem. Abs. 68:10833 s, 1968)

58.

Vaver, V. A., N. V. Prokozova, A. N. Ushakov, L. S. Golovkina and L. D. Bergels on 1967 Diols isolated from lipids of yeast of the Lipomyces genus. Biokhimiya 32:310. (Chem. Abs. 67:17950 r, 1967)

59.

Warner, Richard G. 1962 The nutrient requirements of laboratory rats. The nutrient requirements of laboratory animals. The National Acad. of Sci., National Res. Council Publication 990, P. 51, 1962.

Webster, S. H., E. J. Liljegren and D. J. Zimmer 1947 Organ-body weight ratios for liver, kidneys and spleen of laboratory animals, 1. Albino rat. Am. J. Anat. $81: 477$. 
APPENDIX 
APPENDIX TABLE 1

Properties of 1,3-Butylene Glycol ${ }^{1}$

Specifications

Specific Gravity $20 / 20^{\circ} \mathrm{C}$

Distillation Range, ${ }^{\circ} \mathrm{C}$

Water, wt. \% max.

Acidity, as Acetic, wt. \% max.

Color, Pt-Co Units, max.

Purity, wt. $\%$, min.
$1.004-1.006$

200-215

0.5

0.005

10

99

\section{Hical Properties}

Autoignition temperature, ${ }^{\circ} \mathrm{F}$.

Boiling point, ${ }^{\circ} \mathrm{C}$.

945

Flash point, Tag open cup, ${ }^{\circ} \mathrm{F}$.

Freezing point, ${ }^{\circ} \mathrm{C}$.

207.5

250

Heat of vaporization, cal./g.

Less than -50

Hygroscopicity, water absorbed in 144 hours,

$25-28^{\circ}$ C. at 81 per cent relative humidity, wt. $\% 38.5$

at 47 per cent relative humidity, wt. $\%$

12.5

at 20 per cent relative humidity, wt. $\%$

4.3

Molecular weight, calculated

Pounds per gallon at $20^{\circ} \mathrm{C}$.

90.120

Refractive index, $n^{20}$

8.398

Specific gravity, $20 / 20^{\circ} \mathrm{C}$.

Surface tension, dynes/cm. at $25^{\circ} \mathrm{C}$.

Vapor pressure at $20^{\circ} \mathrm{C}$, $\mathrm{mm}$. of $\mathrm{Hg}$ absolute

1.4401

1.006

37.8

0.06

1 Celanese Chemical Company publication, S-26-10, 1-1970. 
APPENDIX TABLE 2

FDA approvals for the use of 1,3-Butylene Glycol

Direct Food Additive

Solvent for flavors -....... FR 30, 35281, March 17, 1965. FR 30, 8785, July 13, 1965.

Indirect Food Additive

Paper defoaming -....... FR 26, 8100, August 30, 1961. Adhesives -........... FR 27, 12749, December 27, 1962.

Resinous and polymeric coating -...-. FR 28, 2445, March 13, 1963.

Cellophane -.......... FR 29, 6775, May 23, 1964.

Poly vinyl chloride

plastics (1,3-butylene) --- FR 30, 11953, September 18, 1965.

Closure-sealing gaskets -..- FR 30, 16069, December 24, 1965.

Adhesive (1, 3-butylene

glycol dimethacrylate) --- FR 32,6187, April 20, 1967.

Polyurethane resin for

contact with dry food -... FR 32, 15515, November 2, 1967. 


\section{APPENDIX TABLE 3}

Analytical data on 1,3-Butylene Glycol ester samples ${ }^{1}$

\begin{tabular}{llc} 
& \multicolumn{1}{c}{ BGMO } & BGMS \\
\cline { 2 - 3 } Quantity & $5 \mathrm{lbs}$ & $5 \mathrm{lbs}$. \\
Lot & $\mathrm{P}-414$ & $\mathrm{P}-402$ \\
Color & $4 \mathrm{G}+$ & - \\
Free Fatty Acid & 0.9 & 0.7 \\
Cyponification Value & 168.7 & 172.6 \\
Monoester & $72 \%$ & $65 \%$ \\
Diester & - & - \\
Free Glycol & $0.3 \%$ & $\mathrm{Nil}$ \\
Hydroxyl Value & 115.3 & 105.7 \\
Iodine Value & 75.8 & 0.3 \\
Combined Fatty Acid & $79 \%$ Oleic & $70 \%$ Stearic \\
\hline
\end{tabular}

1 Unpublished communication from John P. Hardiman,

Laboratory Manager, Wilson-Martin Company, April 14, 1967.

2 1, 3-Butylene Glycol Mono-Oleate.

3 1,3-Butylene Glycol Mono-Stearate. 
APPENDIX TABLE 4

Composition of vitamin mix and amounts of vitamins supplied per $\mathrm{kg} / \mathrm{diet}$

Vitamin
Commercial product

Commercial product
per $\mathrm{kg} / \mathrm{vit}$. mix
Pure vitamin per $\mathrm{kg} /$ diet
Vitamin $\mathrm{D}_{3}$ and

Vitamin A Palmitate, 325,000 IU/g each

Vitamin A Palmitate, 325,000 IU/g

dl-Alpha tocopheryl acetate, $275 \mathrm{IU} / \mathrm{g}$

Menadione (2-methyl-napthoquinone)

Thiamine HCL

Riboflavin

Nicotinic acid amide

Vitamin C

Pyridoxine $\mathrm{HCl}$

Para-amino benzoic acid

d-Biotin, $1 \%$

D-Panthothenic acid (calcium salt)

Folacin, 3\%

i-Inositol (meso)

Vitamin $\mathrm{B}_{12}, 0.1 \%$

Choline chloride

Cellulose
Roche $A \& D_{3}$ Palmitate

Roche

Roche

Gen. Biochem.

Roche

Roche

Gen. Biochem.

Roche

Roche

Gen. Biochem.

Roche

Gen. Biochem.

American Cynanamid

Gen. Biochem.

Roche

Gen. Biochem.

Gen. Biochem.
500 IU

500 IU

$11,000 \mathrm{IU}$

$100 \mathrm{IU}$

$5.0 \mathrm{mg}$

$10.0 \mathrm{mg}$

$20.0 \mathrm{mg}$

$50.0 \mathrm{mg}$

$200.0 \mathrm{mg}$

$10.0 \mathrm{mg}$

$100.0 \mathrm{mg}$

$50.0 \mathrm{mg}$

$50.0 \mathrm{mg}$

$66.6 \mathrm{mg}$

$200.0 \mathrm{mg}$

$50.0 \mathrm{mg}$

$20.0 \mathrm{mg}$

TOTAL $\quad 1000.0000 \mathrm{~g}$ 
COMMENTS - HIS TOPA THOLOGIC EVALUATION OF TISSUES

Using the control animals as a point of reference, frozen liver sections stained with oil red-O for lipid revealed the following:

1. BG increased stainable liver lipid slightly in the male rats, but not in the females.

2. BGMO had no effect on stainable liver lipid.

3. BGMS sharply increased stainable liver lipid in male rats; a slight increase was noted in females.

All lipid accumulations were in the periportal area and extended toward the centrilobular zone to encompass a small periportal zone, as in the control animals as much as the entire lobule illustrated by BGMS male rats. The stainable lipid is without pathologic significance, but the BGMS males would require further study even though in their case, it is of doubtful significance.

In addition to frozen sections stained for lipid, the liver, spleen, heart, aorta, testes, kidney and adrenal glands were embedded in paraffin, sectioned at 6 microns, stained with hematoxylin and eosin and examined microscopically for histopathologic alterations. All tissues were within normal limits and any changes observed were those associated with normal processes of aging in the rat. On the basis of these observations, none of the chemicals fed to the animals appeared to have significant adverse effects on any of the tissues examined. 
$\mathrm{F}_{2}$ Generation

BGMS Animals.

6pleens -5 males.

A mild hyperplasia of lymphoid follicles and some slight increase in the amount of iron pigment in all of the spleens.

Spleens - 9 females.

A mild hyperplasia of the lymphoid follicles, but no other significant alterations.

There also seems to be a slight increase in the amount of pigment containing cells.

Testes -5 males.

Normal spermatogenesis.

Aortas -5 males.

There are no lesions in the aortas.

Hearts -5 males.

No significant changes observed in any of them.

Kidneys -5 males.

No significant change observed in any of them.

Adrenals - 5 males.

Varying degrees of lipid infiltration from mild to moderate in the adrenal cortex.

No other significant changes.

Kidneys - 9 females.

Small amount of calcification of the tubules at the CM junction of two of the kidneys; otherwise normal.

Adrenals - 9 females.

A small amount of lipid accumulated in the cortex.

No other significant changes.

Livers -5 males.

Variable degrees of lipid accumulation in the liver which should be described previously from the fat stains, but no other significant alterations.

Livers - 9 females.

No significant change observed in any of the livers.

Nodular structure.

Listed as a fat pad tumor. A benign lipoma with some evidence of steatosis and inflammatory response. 
BG Animals.

Spleen-5 males.

Moderate myeloid metaplasia and a very mild overall atrophy.

Spleen-10 females.

A mild myeloid metaplasia and a minimal overall atrophy with some depletion of small lymphocytes.

No other significant alteration.

This change is somewhat suggestive of a general lack of normal weight gain.

Testes -5 males.

Normal spermatogenesis.

A few tubules indicate signs of a mild degenerative atrophy, but the organs are on the average normal.

Aortas - 5 males.

No significant change observed in any of them.

Hearts -5 males.

A few small foci of myocardial necrosis in two of the hearts and edema of the valves and roots of the valves in one.

Kidneys - 5 males.

Minimal tubule protein precipitate.

No other significant changes observed.

Adrenals - 5 males.

Minimal to mild lipid accumulation in the cortex.

No other significant changes.

Kidneys - 9 females.

A small amount of protein precipitated tubules of some of the kidneys and a minimal amount of focal interstitial nephritis in two of them.

No other significant change.

Adrenals - 9 females.

A moderate fatty infiltration in most of them.

No other significant change observed.

Liver - 5 males.

Periportal lipid infiltration in several of the kidneys, but no other significant change.

Livers - 9 females.

No significant change observed in the livers. 
$\mathrm{F}_{2}$ Generation

Spleens from 5 male animals BGMO.

Normal with the usual hyperplasia of the lymphoid follicles. The only outstanding change is a slight increase in pigment which is normally associated with the spleen, some of which is precipitated because of method of fixation.

Spleens-10 females.

A mild overall atrophy of the spleen of no significance and a mild to moderate hyperplasia of the RE component of the spleen. All of these changes are within a normal range, although there are a few scattered wacuolated cells indicative of degenerating histiocytes.

Testes from 5 males.

Testes: Normal spermatogenesis

Aortas -5 males.

NLO.

Hearts -5 males.

A small focus of myocardial degeneration in one heart.

Kidneys from 5 males.

A mild tubular change with a slight amount of protein precipitate within the lumen but no significant alterations observed. All kidneys appear to be within a normal range.

Adrenal glands - 5 males.

A moderate increase in the amount of lipid in the cortex. It is quite noticeable in the inner one half of the cortex in all organs examined. The glomerulosa also has an increased amount of lipid in its constituent cells.

Kidneys from 10 females.

A small amount of tubular calcification at the CM junction in 3 kidneys and a mild tubular change in the kidneys of most of the others although it is not of any great consequence. Such changes are often observed in the kidneys of apparently normal animals.

Adrenals-10 females.

No significant alteration in any of the $m$.

Livers -5 males.

A mild periportal lipid infiltration in one of five. No other significant change. (These have already been examined with oil red $O$ fat stains.

Livers-10 females.

No significant change observed in any of the liver sections

Ovarian cyst in one female. The section contains a highly atrophic and cystic ovary and a horn of the uterus which is essentially normal in the resting state. 
$\mathrm{F}_{2}$ Generation

Spleens- 5 males.

No significant alterations.

Spleens-10 females.

No significant change. There is a very mild or minimal myeloid metaplasia, but the follicles in the RE system are normal.

Testes -5 males.

Normal spermatogenesis.

Aortas -5 males.

No significant change observed.

Hearts - 5 males.

No lesions observed in any of the hearts.

Kidneys - 5 males.

Mild protein precipitate in the tubules and a minimal amount of cast formation. No other significant changes.

Another kidney section in which there is a small amount of focal interstitial necritis.

Kidne ys - 10 females.

A very small amount of tubule damage with some cast formation all of which is minimal.

Adrenals-10 females.

No significant change. There is some artifactual alteration because of methods of harvesting and fixation which appears to be of no consequence.

Liver -5 males.

A periportal lipid accumulation moderate in severity. No other significant change.

Liver - 10 females. No significant change. 


\section{FROZEN SECTIONS, OIL RED-O STAIN FOR LIPID}

Control, males.

$1+$ liver lipid, periportal.

Control, females.

0 --few scattered cells with fat.

$\mathrm{BG}$, males.

$2+$ liver lipid, periportal.

BG, females.

0 liver fat.

BGMO, males.

0-1+ liver lipid, periportal and scattered throughout lobule.

BGMO, females.

0 liver fat.

BGMS, males.

$4+$ liver lipid, minimal fibrosis.

BGMS, females.

2+ liver lipid, periportal. 


\section{METHODOLOGY USED FOR CLINICAL CHEMISTRY}

\section{TOTAL PROTEIN}

A standard AutoAnalyzer N Method using a modified biuret reaction. Copper, in alkaline solution, forms a purple complex with the peptide linkages of amino acids in a protein. The protein stream is mixed with the biuret reagent and the developed color is measured at $550 \mathrm{mu}$ in a $15 \mathrm{~mm}$. flowcell.

\section{ALBUMIN}

The procedure is based on the quantitative binding of the anionic dye, 2-(4'-hydroxyazobenzene) benzoic acid (HABA), specifically to serum albumin. It is based on the work of A. J. Ness, et al., Clin. Chim. Acta 12: 532 (1965), who have extensively modified the original method of D. D. Rutstein et al. , J. Clin. Invest. 33: 211 (1964).

The changes include use of a phosphate buffer, $\mathrm{pH} 6.2$; increased HABA dye concentration; and use of human albumin as a reference standard.

These changes have been adapted to the AutoAnalyzer by H. H. Nishi and A. Rhodes, Automation in Analytical Chemistry - Proceedings of the 1965 Technicon Symposium.

\section{CALCIUM}

A standard N Method originally described by G. Kessler and M. Wolfman, Clin. Chem. 10: 686-703 (1964).

The diluted serum sample is mixed with $1 \mathrm{~N}$ hydrochloric acid to release protein-bound calcium. This is dialyzed into a recipient stream of Cresolphthalein Complexone solution. A colored complex between calcium and dye is formed upon the addition of diethylamine, which results in an alkaline mixture. The solution is thermostated at $37^{\circ} \mathrm{C}$. before entering the Colorimeter. The developed color is measured in a $15 \mathrm{~mm}$. flowcell at $580 \mathrm{mu}$.

\section{ALKALINE PHOSPHATASE}

This N Method (Marsh et al., Clin. Chem. ; 119 (1959) is 


\section{WALINE PHOSPHATASE (Continued)}

a modification of the King-Armstrong procedure.

The method is based on the enzymatic hydrolysis of phenyl disodium phosphate by alkaline phos phatase during incubation at $37^{\circ} \mathrm{C}$.

The released phenol is condensed with 4-aminoantipyrine followed by oxidation with alkaline potassium ferricyanide to give a red product. This is measured at $505 \mathrm{mu}$ in a $15 \mathrm{~mm}$. flowcell.

\section{TOTAL BILIRUBIN}

The $\mathrm{N}$ Method for total bilirubin is based on the procedure of Jandrassik and Grof, Biochem. Z. 297: 81 (1938), as adapted by Gambino and Schreiber, Technic on Symposium (1964).

Bilirubin is reacted with diazotized sulfanilic acid in the presence of a caffeine-sodium benzoate reagent to form colored azobilirubin. The alkaline azobilirubin is measured at $600 \mathrm{mu}$ in a $15 \mathrm{~mm}$. flowcell.

\section{BLOOD UREA NITROGEN}

A modification of the method of Marsh et al., Clin. Chem. 11: 624-627 (1965).

A colored product is formed when urea, in relatively weak acid solution, reacts with diacetyl monoxime. The presence of thiosemicarbazide and ferric ion intensifies the color of the reaction. The mixture is heated at $95^{\circ} \mathrm{C}$. and read in a $15 \mathrm{~mm}$. flowcell at $520 \mathrm{mu}$.

\section{GLUCOSE}

The method is a modification of the procedures of M. E. Brown, Diabetes 10: 60-62 (1961); and D. Bittner and M. McCleary, Am. J. Clin. Path. 40: 423-424. Abst. (1963).

A cupric-neocuproine chelate is reduced by glucose in an alkaline medium resulting in a highly colored cuprousneocuproine complex. After heating at $95^{\circ} \mathrm{C}$, the absorbance 


\section{HODOLOGY (Continued)}

\section{MCOSE (Continued)}

is measured in a $15 \mathrm{~mm}$. flowcell at $460 \mathrm{mu}$.

Interference by ascorbic acid and sulphydryl groups is reduced by treating the dialysate with sodium carbonate before addition of the color reagent.

\section{W GLUTAMIC-OXALACETIC TRANSAMINASE (SGOT)}

The method is based on the procedure of Morganstern, et al. , Clin. Chem. 12: 95-111 (1966). The oxalacetic acid produced by the action of the enzyme is dialyzed and then reacted with the diazonium salt of N-butyl-4-methoxymetanilamide (Azoene Fast Red, PDC).

Serum samples are incubated with as partate-ketoglutarate substrate at $37^{\circ} \mathrm{C}$., dialyzed against citrate buffer and then mixed with the dye. Color is developed at $37^{\circ} \mathrm{C}$. and the product is read at $460 \mathrm{mu}$ in a $15 \mathrm{~mm}$. flowcell.

Dialysis eliminates the need for a serum blank determination.

\section{CHOLESTEROL:}

This method is based on a modification (Huang et al. , Anal. Chem. 33: 1405 (1961) of the Lieberman-Burchard reagent for use in the direct determination of serum cholesterol.

Serum is mixed with a stable reagent composed of acetic acid, acetic anhydride and sulfuric acid. The developed color is stabilized in a $37^{\circ} \mathrm{C}$. heating bath and read at $630 \mathrm{mu}$ in a $15 \mathrm{~mm}$ flowcell.

LACTIC DEHYDROGENASE:

The method is based on the procedure of Hochella and Weinhouse, Anal. Biochem. 13; $322-335$ (1965). Lactic dehydrogenase catalyzes the oxidation of L-Lactate by NAD in the lactate to pyruvate reaction. Enzyme activity is determined by coupling this reaction to the reduction of the tetrazolium dye (INT) with diaphorase serving as 
WHODOLOGY (Continued)

LACTIC DEHYDROGENASE (Continued)

an intermediate electron carrier.

All reactions are carried out at $37^{\circ} \mathrm{C}$. and the absorbance is measured at $505 \mathrm{mu}$ in a $15 \mathrm{~mm}$ flowcell.

\section{INORGANIC PHOSPHATE:}

This is a modification of the standard N Method and is based on the formation of phosphomolybdic acid which is then reduced by stannous chloride. The stannous chloride replaces the less sensitive 1-amino-2-napthol-4-sulfonic acid used in the $\mathrm{N}$ Method.

Serum is mixed with, and also dialyzed against, lN HCl. The dialyzable phosphate is then mixed with an acidic solution of ammonium molybdate, with the formation of phos phomolybdic acid, and this is immediately followed by reduction. The reaction mixture is heated at $95^{\circ} \mathrm{C}$. and the blue product is measured at $660 \mathrm{mu}$ in a $15 \mathrm{~mm}$ flowcell.

URIC ACID:

Lofland et al. (1965 Technic on Symposium) described an automated procedure for the determination of uric acid, using the cupric-neocuproine method originally described by Bittner et al., Am. J. Clin. Path. 40: 423-424, abst. (1963). In the SMA, a similar redox dye, bathocuproine sulfonate, is used for increased sensitivity.

Serum is dialyzed and the recipient stream is treated with sodium hydroxide to reduce interference by ascorbic acid and the sulphydryl groups. Acidic cupric-bathocuproine, is then added and the copper is reduced by the uric acid. The color formed is measured at $480 \mathrm{mu}$ in a $15 \mathrm{~mm}$ flowcell. The acidic conditions eliminate interference by reducing sugars, e.g., glucose.

The new procedure appears to be more specific than the standard N Method and avoids the use of cyanide. 


\section{Glycerol and Neutral Fat}

U-method

TC-GL. Cat No: 15989 TNAA

for ca 25 determinations each

\section{Biochemica Test Combination}

Concentration of solutions:

$10.1 \mathrm{M}$ triethanolamine buffer, $\mathrm{pH} 7.6 ; 4 \mathrm{mM} \mathrm{Mg} \mathrm{SO} 4$.

$26 \mathrm{mM} \mathrm{NAOH} ; 33 \mathrm{mM}$ ATP; $11 \mathrm{mM}$ PEP.

$32 \mathrm{mg}$. LDH $/ \mathrm{ml}$.; $1 \mathrm{mg}$. PK/ml.

$42 \mathrm{mg} . \mathrm{GK} / \mathrm{ml}$.

\section{Prepuration of solutions}

1 Dissolve contents of bottle i in $150 \mathrm{ml}$, redist, water. (Stable for one year at room temperature.)

2 If necessary, dissolve contents of one boltte 2 in $2 \mathrm{ml}$.

2 rediat. water. (Stable for two weeke at approx. $+4^{\circ} \mathrm{C}$.)

3 Use suapension in bottle 3 undiluted.

3 (Stable for one year at epprox. $+4^{\circ} \mathrm{C}$.)

4. Use suspension in bottle 4 undiluted.

(Stable for one yeer at epprox. $+4^{\circ} \mathrm{C}$.)

In sddition

Alcoholic potessium hydroxids, $0.5 \mathrm{~N}$ : dissolve $3.3 \mathrm{~g} .85 \%$ potassium hydroxide A. A. Free from otycerol in $10 \mathrm{ml}$. redist. water, after cooling fill up to $100 \mathrm{ml}$. with pure sbe. ethanol.

Megnesium wiphate solution, 0.15 M, Cat. No.: 15907 TYAQ or dissolve $3.7 \mathrm{~g}$. $\mathrm{MgSO}_{4}$ - $7 \mathrm{H}_{2} \mathrm{O}$. A. F. with redist. water and make up to $100 \mathrm{ml}$.

\section{Please note}

Uee only freah serum, free from heemolyais.

The dotermination of neutral fat should alwaye be preceded by determination of free olycerol.

Dilute atrongly lipaemic sera $1+8$ with physiol. saline.

It is recommended to determine the blenk once for each package. For this purpose, the determination is performed with water instead of serum. The optical denatty difference posaibly resulting after the addition of suspension 4 is always to be deducted from the optical denaity difference oblained with the sampla. When using a Folch-Sperry extract from tissue or serum, eveporate the mixture of the solvente after filtration. The residue is saponified with $0.5 \mathrm{ml}$. alcoholic potassium hydroxide described below.

\section{Spectropheicmetric measurementa}

Wevelength: 366.340 , or $334 \mathrm{~nm}$.

Glass cuvette: $1 \mathrm{~cm}$. linht path

Temperature: $20-25^{\circ} \mathrm{C}$

Messure egainst air or dilute picric acid solution (1 - 2 drops of $1.2 \%$ prenic aced in $100 \mathrm{ml}$. of water)

\section{Determination of sheered}

\begin{tabular}{|c|c|c|}
\hline \multicolumn{3}{|l|}{ Pipette into cuvette: } \\
\hline & routine asesy & eemi-microsenewy \\
\hline $\begin{array}{l}\text { solution } 1 \\
\text { solution } 2 \\
\text { serum or supematant } \\
\text { fluid } \\
\text { suspension } 3\end{array}$ & $\begin{array}{l}2.50 \mathrm{mi} \\
0.10 \mathrm{ml} \\
0.50 \mathrm{mi} \\
0.02 \mathrm{mi}\end{array}$ & $\begin{array}{l}1.00 \mathrm{ml} \\
0.05 \mathrm{ml} \\
0.20 \mathrm{ml} \\
0.01 \mathrm{ml}\end{array}$ \\
\hline \multicolumn{3}{|c|}{$\begin{array}{l}\text { mix with plestic paddle and allow to stend for } 10 \mathrm{~min} \text {. at } \\
\text { room temperature, then messure optical demeity } E_{1} \text {. }\end{array}$} \\
\hline suspension 4 & $0.02 \mathrm{mi}$ & $0.01 \mathrm{ml}$. \\
\hline \multicolumn{3}{|c|}{$\begin{array}{l}\text { mix in and wait until reaction stops (approx. } 10 \text { min.), or } \\
\text { thake } 3-5 \text { readings at } 2 \text { min. intervals and extrepolate } E_{2} \\
\text { to the time of the addition of suspension } 4 \text {; refer to } \\
\text { "Biochemica-Test-Combinations. Principles and Prectice". } \\
E_{1}-E_{2}=\Delta E \text {. }\end{array}$} \\
\hline
\end{tabular}

With optical density differences exceeding 0.400 (366 nm.) or 0.800 (340, $334 \mathrm{~nm}$.) mix $0.1 \mathrm{mi}$. serum or eupernatant fluid wth $0.9 \mathrm{ml}$. of phytiol. saline and repeat assay with $0.5 \mathrm{ml}$. or $0.2 \mathrm{ml}$. of this dilution (result $\times 10$ ).

\section{Seponitication}

\begin{tabular}{|c|c|}
\hline \multicolumn{2}{|l|}{ Pipette into centrifuge tube: } \\
\hline serum & $0.2 \mathrm{ml}$. \\
\hline alcoholic poteseium hydroxide & $0.5 \mathrm{ml}$. \\
\hline \multicolumn{2}{|c|}{$\begin{array}{l}\text { mix, clowe centerifuge tube with clean stopper or perafilme } \\
\text { and allow to stand in water bath for } 30 \mathrm{~min} \text {. at } 70^{\circ} \mathrm{C} \text {, then } \\
\text { allow to cool to room temperature. }\end{array}$} \\
\hline megnesium sulphnte solution & $1.0 \mathrm{ml}$. \\
\hline \multicolumn{2}{|c|}{$\begin{array}{l}\text { mix woll, centrifuge, use } 0.5 \mathrm{ml} \text {. and } 0.2 \mathrm{ml} \text {. of the clear } \\
\text { supernotent fluid respectively for assay (see above). }\end{array}$} \\
\hline
\end{tabular}

\section{Calculation}

The retio of the assay volumes between the routine and semimicro aseaye is not exactly $2.5: 1$. The difference, however, is leas than $1 \%$ and can be neglected. The same calculation factors can therefore be used for both the routine and semimicro-secays.

\section{Free styearol:}

$\Delta E_{34} \ldots . . \times 17.5=m g . \%$ olycerol in serum

$\Delta E_{300} \times \quad 9.3=\mathrm{mg} \%$ olycerol in cerum

$\Delta E_{334}$ nam. $X \quad 9.6=m g . \%$ glycerd in serum

\section{Total ohyerol sher euponilleation:}

$\Delta E_{346}$ m. $\times 149=m g . \%$ total glycerol in serum $\Delta E_{300} \mathrm{~m} . \times 79=m g . \%$ total glycerol in serum $\Delta E_{334}$ m. $\times \quad 82=m g . \%$ total alycerol in serum $m g . \%$ total glycerol $-m g . \%$ free glycerol $=$ $\mathrm{mg} \%$ glyceride glycerol

$m g . \%$ glyceride glycard $\times 8.62=m g . \%$ nouterl fat

Nonnal values in cerum 1 : free stycerol: $0.5-1.7 \mathrm{mo. \%}$ glyceride olycerol: $7.7-17.0 \mathrm{mg} . \%$ neutral fat: $74-172 \mathrm{mg} . \%$

\section{Acterences:}

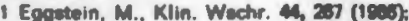

2 Eprotoin, M. and F. H. Krevte, KIIn. Wechr, 4h, 202 (1000);

3 Schmidt. F. H. of al., Z. klin. Chem. and Mlin. Blochem \&, 158 (180)

\section{BOEMRINGER MANNHEIM GMBH \\ MANNHEIM \\ Biochemical Department}

the edition ices 
THE CHARLES RIVER LABORA TORIES, INC.

1018 Beacon Street

Brookline, Mass. 02146

REgent 4-2000

June 26,1969

NORMAL VALUES FOR RATS

BASED ON A STUDY OF CHARLES RIVER ANIMALS

Patient: Male $288 \mathrm{gms} \quad$ Specimen Received:

ANALYSIS RESULTS ADULT NORMAL RANGE

Cholesterol

Calcium

In. Phosphorus

Bilirubin, T.

Albumin

Total Protein

Uric Acid

Urea Nitrogen

Glucose (True)

L. D. H.

Alk. Phosphatase

SGO-Transaminase

Globulin

A/G Ratio

Hematocrit

Red Blood Count

White Blood Count

Hemoglobin

Differential:

$100 \quad \mathrm{mg} \%$

$14 \mathrm{mg} \%$

$11 \mathrm{mg} \%$

$0.6 \mathrm{mg} \%$

$4.4 \mathrm{gm} \%$

$7.2 \mathrm{gm} \%$

$6.6 \mathrm{mg} \%$

$42 \mathrm{mg} \%$

$370 \mathrm{mg} \%$

350 W.U.

50 K-A.U.

190 K. U.

$2.8 \mathrm{gm} \%$

1.6

$45 \quad \%$

$5.7 \mathrm{~m} / \mathrm{cmm}$ $10,100 / \mathrm{cmm}$

$14.1 \mathrm{gm} \%$

Polys-14\%; Lymphs-86\%;

Rbc's and Platelets - Normal
$150-300 \quad \mathrm{mg} \%$

8. $5-11 \mathrm{mg} \%$

2. $5-4.5 \mathrm{mg} \%$

$0.2-1.0 \quad \mathrm{mg} \%$

3. $5-5.0 \mathrm{gm} \%$

6. $0-8.0 \mathrm{gm} \%$

2. 5-8. $0 \mathrm{mg} \%$

10-20 $\mathrm{mg} \%$

65-110 $\mathrm{mg} \%$ (Fasting)

30-130 W.U.

4. 0-17 K-A.U.

10-40 K. U.

1. $2-3.2 \mathrm{gm} \%$

1. $1-2.2$

M-40-54 \%; F-37-47\%

$\mathrm{M}-4.5-6.0 \mathrm{~m} ; \mathrm{F}-4.0-5.5 \mathrm{~m}$ $5,000-10,000$

M-13-18 gm\%; F-11-16 gm\% 


\begin{tabular}{|c|c|}
\hline $\begin{array}{l}C \\
C\end{array}$ & ANALYSIS OF VARI ANCE \\
\hline C & $\begin{array}{l}\text { TWO WAY ANALYSIS OF VARIANCE (MIT) } \\
\text { EMIL F GRENDA F - OIO }\end{array}$ \\
\hline 6 & REVISED, MARY ANN HALL, JANUARY 7, 1969 \\
\hline$\underline{c}$ & IHIS PROCRAM PERFORMS ANALYSIS OF VARIANCE FOR TWO VARIABLES OF \\
\hline $\bar{C}$ & CLASSIFICATION WITH REPLICATE MEASUREMENTS IN EACH GROUP. \\
\hline C & NR (NUMBER OF ROWS) MUST BE LESS THAN OR EQUAL IO 30 \\
\hline $\bar{C}$ & NC (NUMBER OF COLUMNS) MUST BE LESS THAN OR EQUAL TO 30 \\
\hline C & NC * NR (NUMBER OF GROUPS) MUST BE LESS THAN OR EQUAL TO 60 \\
\hline $\begin{array}{l}C \\
C\end{array}$ & $\begin{array}{l}\text { THE NUMBER OF REPLICATES IN EACH GROUP MUST BE LESS THAN OR } \\
\text { EQUAL TO } 30\end{array}$ \\
\hline C & \\
\hline C & THE OBSERVATIONS ARE READ IN ROW ORDER. FOR EXAMPLE IF $N C=2$, $N R=3$, \\
\hline C & AND THERE ARE DUPL ICATE DBSERVATIONS FOR EACH GROUP, THE DATA \\
\hline & ARE READ IN AS FOLLOHS - X111, X112, X121, X122, X211, x 212 , \\
\hline C & $\begin{aligned} x 221, & \times 222, \times 311, x 312, x 321, x 322 \\
\text { COMMON } & \text { NPGR }(60), x(60,30), x B A R(60), X V A R(60), X S T D E V(60),\end{aligned}$ \\
\hline & $\begin{array}{l}1 \text { XSTER }(60), \text { TAB }(30), X X C(30), X X R(30), \text { IALP(2), } X B P S E R(60), \\
2 \text { XBMSER }(60), X C T(30), X R T(30), \text { ICULL, JCULL, NC, NGR, IDFE, NR,VARE }\end{array}$ \\
\hline & $\begin{array}{l}\text { LAST }=-975846336 \\
\text { READ }(5,1000) \text { ICULL,MSD }\end{array}$ \\
\hline 1 & $\operatorname{READ}(5,8282)(I A L P(K 1), K 1=1,27)$ \\
\hline 8282 & FORMAT (26A3, A2) \\
\hline 71 & $\begin{array}{l}\text { IF ( I ALP( } 1)-L A S T) 71,999,71 \\
\text { CONTINUE }\end{array}$ \\
\hline 1000 & $\begin{array}{l}\text { READ }(5,1000) N C, N R \\
\text { FORMAT }(814)\end{array}$ \\
\hline & $\begin{array}{l}\text { NGR }=N C * N R \\
\text { READ }(5,1010)(N P G R(1), I=1, N G R)\end{array}$ \\
\hline
\end{tabular}




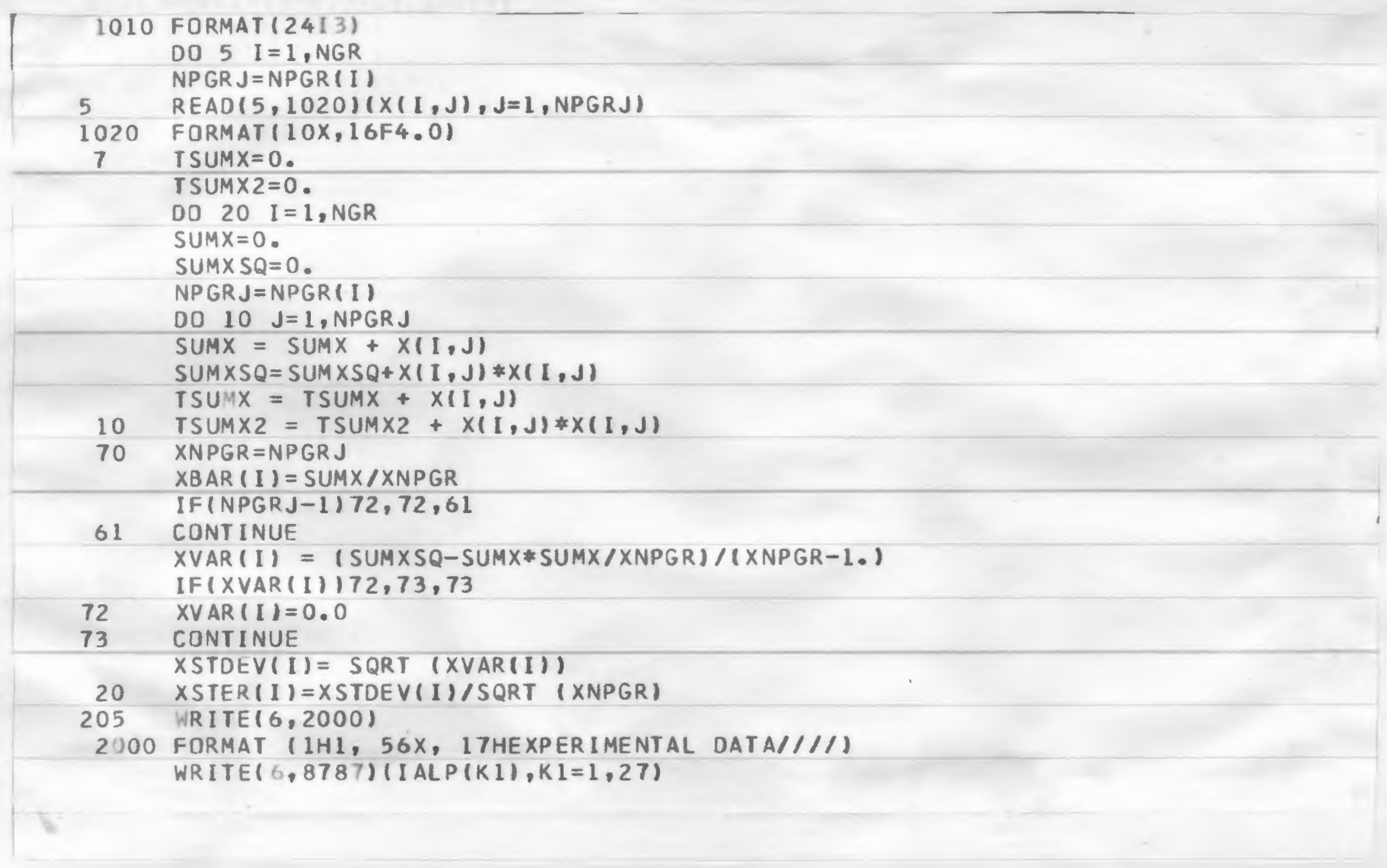




\section{Computer Analysis of Variance Program - continued}

8781 FDRMAT (20X, 26A3,A2///I

DO $22 I=1$, NGR

NPGRJ = NPGR 11$)$

22 WRITE $(6,2010) 1,(X(I, J), J=1, N P G R J)$

2010 F DRMAI ( $\angle / 2 X, 6 H G R O U P, 2 X, 13,5 X, 8 F 10.3 /(18 X, 8 F 10.3))$

DO $23 I=1, N G R$

$X B P S E R(I)=X B A R(I)+X S T E R(I)$

23 XBMSER(I) =XBAR(I) $X$ XSTER (I)

WR ITE $(6,2020)$ (I, NPGR (I), XBARII), XVAR(I),XSTDEV(I),XSTER(I),

1 XBPSER ( I ), XBMSER (I), I=1,NGR)

2020 FORMAT (IHI, $2 X, 5$ HGROUP, 4X, 6HNUMBER, $5 X, 4 H M E A N, 8 X, 8$ HVARI ANCE, $8 X$,

2

3

13 HSTANDARD DEV $, 4 X, 13 H S T$ ANDARD ERR \& $4 X, 13 H M E A V+S T D$. ERR —.

C $4 X, 13$ HMEAN-STD.ERR. $/(1,1 X,[5,5 X, 15,5 X, F 8.3,5 E 17.5) 1$

C SUMS OF SQUARES

$N=0$

TOTAL

DO $25 I=1, N G R$

$25 \quad \mathrm{~N}=\mathrm{N}+\mathrm{NPGR}(\mathrm{I})$

$X N=N$

$C T=T$ SUMX $* T$ SUMX $/ X N$

ANSS $=$ T SUM $\times 2-$ CT

C

$G=0$.

GRDUPS

DO $30 \quad I=1$, NGR

$X N P G R=N P G R(I)$

$30 G=G+X B A R(I) * X B A R(I) * X N P G R$ GR SS $=G-C T$

C

$T R=0$.

ROWS

DO $40 \mathrm{~J}=1, N R$

$R=0$.

$\mathrm{TN}=0$.

$L I=(J-1) * N C+1$ 
Computer Analysis of Variance Program - continued

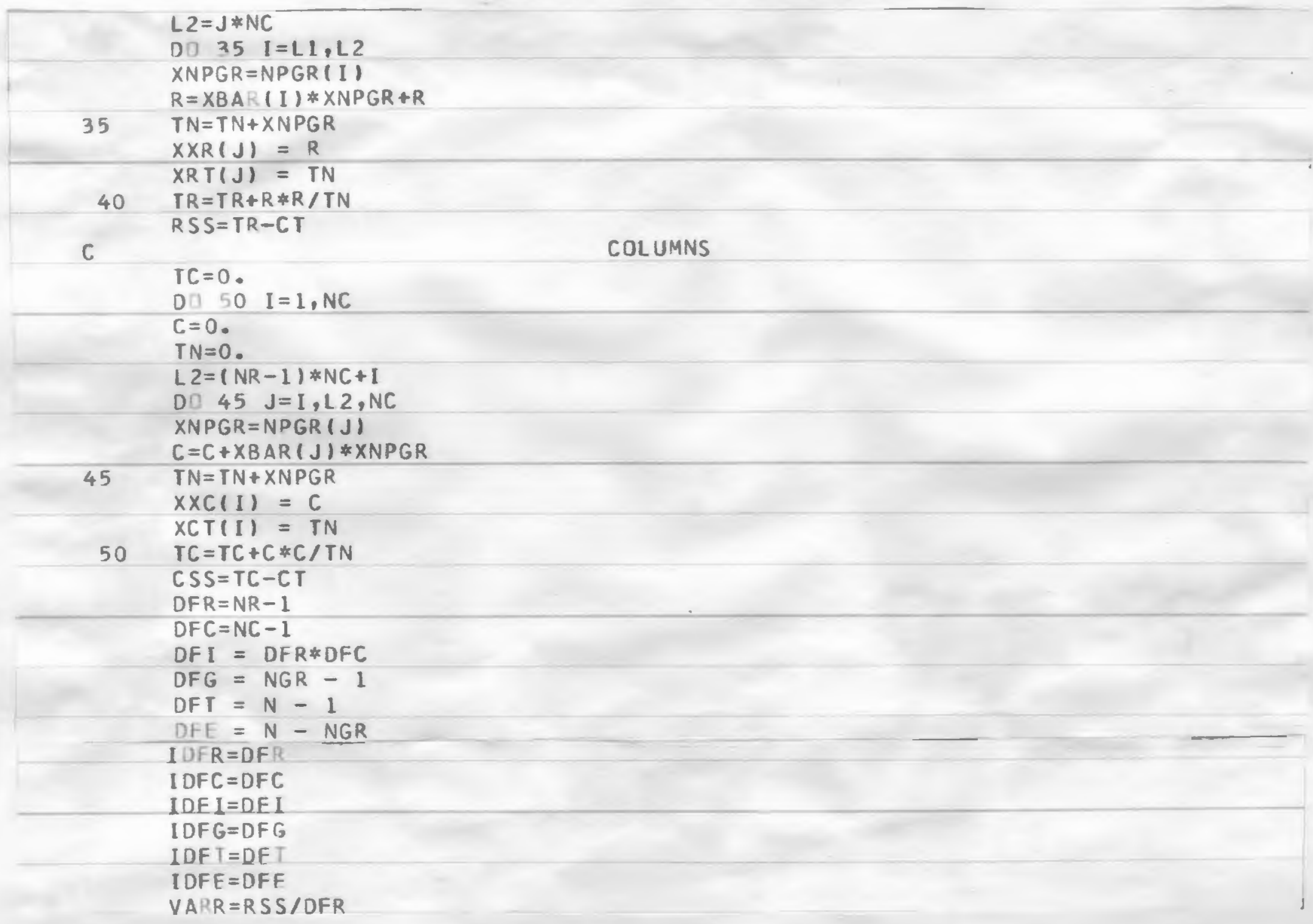




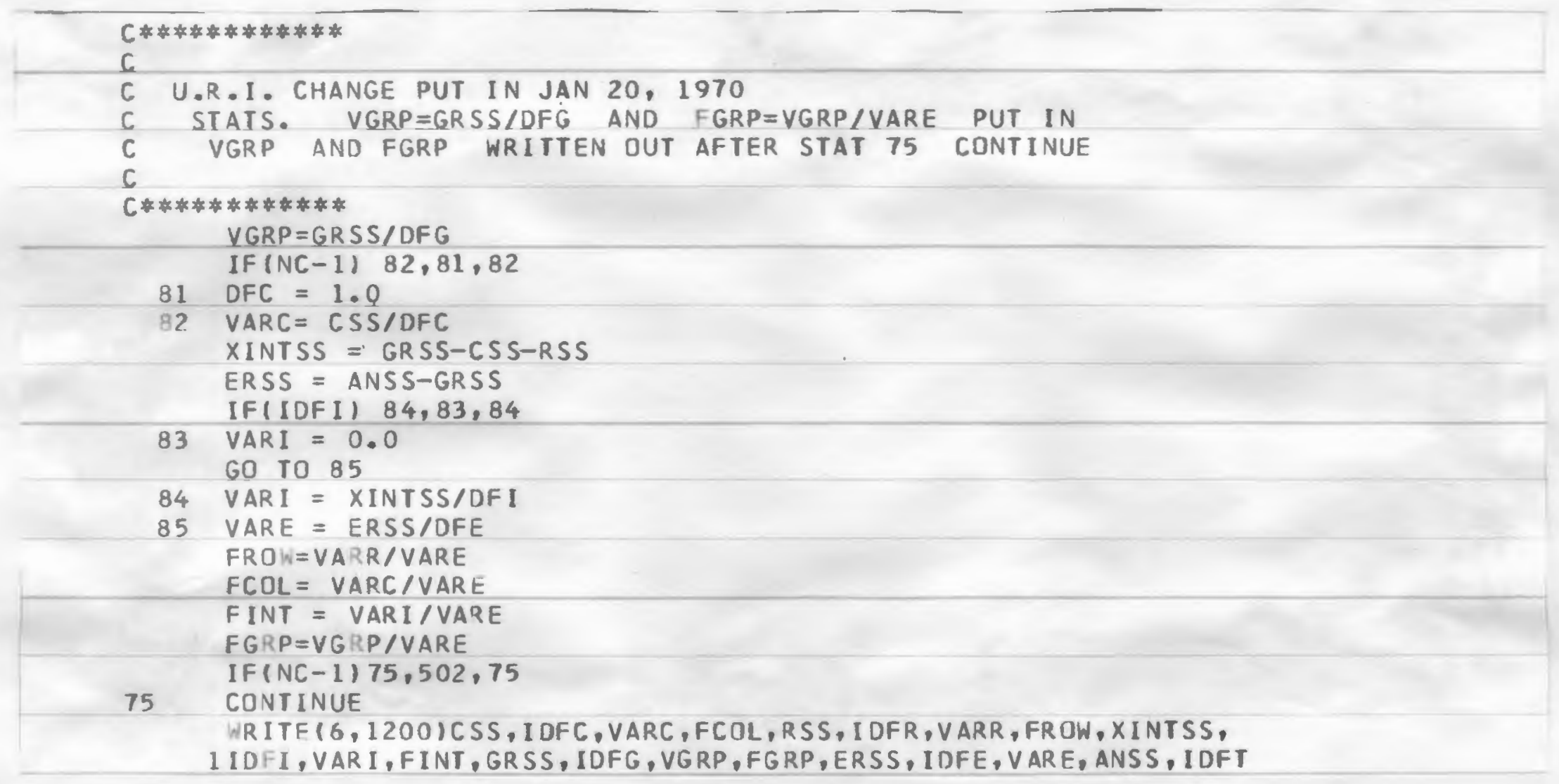


1200 FORMAT $(1 H 1,30 \bar{X}, 2$ OHANALYSTS OF VARIANCE/IHO, $19 X, 14 H S U M$ OF SQUARES, $25 X, 4 H D . F, 3 X, 1$ IHMEAN SQUARE, 5X, 7HF RATIO/ IHO, 6X,7HCOLUMNS,6X,

3 E $12,5,7 X, I 4,2 X, E 12,5,3 X, F 8,3, / 1$ HO $6 X, 4 H R O W S, 9 X, E 12,5,7 X, I 4$,

$42 X, E 12.5,3 X, F 8,3,11 H 0,6 x, 6 H I N T E R, .7 X, E 12.5,7 X, I 4,2 X, E 12.5$,

$53 X, F 8.3 / 1 H 0,6 x, 6 H G R D U P S, 7 X, E 12,5,7 X, I 4,2 X, E 12.5,3 X, F 8,3, / 1 H O$,

$66 X, 5 H E R R O R, 8 X, E 12.5,7 X, I 4,2 X, E 12,5 / / 1 H 0,6 X, 5 H T O T A L, 8 X, E 12.5$,

$77 x,(4)$

GO TO 501

502 WRITE (6,503)RSS, IDFR, VARR, FROW, ERSS, IDFE, VARE, ANSS, IDFT

503 FORMAT $(1 \mathrm{H}, 30 \mathrm{X}, 2$ OHANALYSIS OF VARIANCE/LHO, $19 X, 14 \mathrm{HSUMOF}$ SQUARES, $15 X, 4 \mathrm{HD}, F, .3 X, 11 \mathrm{HMEAN}$ SQUARE, 5X,7HF RATIO/1HO,6X,6HGROUPS, 7X,E 12.5, $27 X, I 4,2 X, E 12.5,3 X, F 8.3, / 1 H 0,6 X, 5 H E R R O R, 8 X, E 12.5,7 X, I 4,2 X, E 12.5, / /$

$31 H 0,6 X, 5 H T O T A L, 8 X, E 12.5,7 X,[4]$

501 IF (MSD-1) $990,76,990$

76 CONTINUE

CALL LSO

990 IF ( I CULL-1) 1,77, I

77 CONTINUE CALL CULL IF ( JCULL-1) 78,7,78

78 CONTINUE GO TO 1

999 WR I TE $(6,500)$

500 FORMAT (15H END OF PROGRAM) END 
Computer Analysis of Variance Program - continued

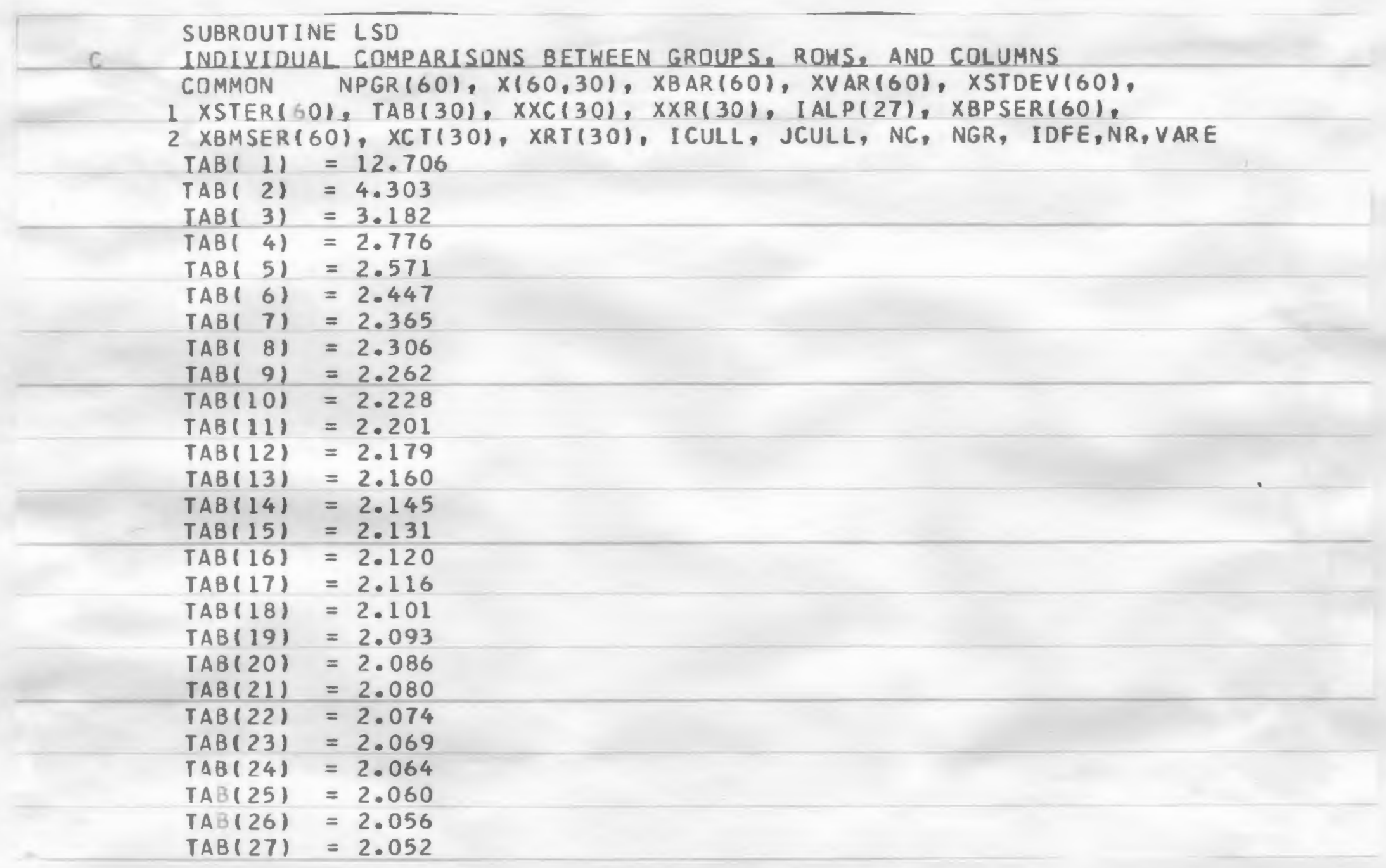




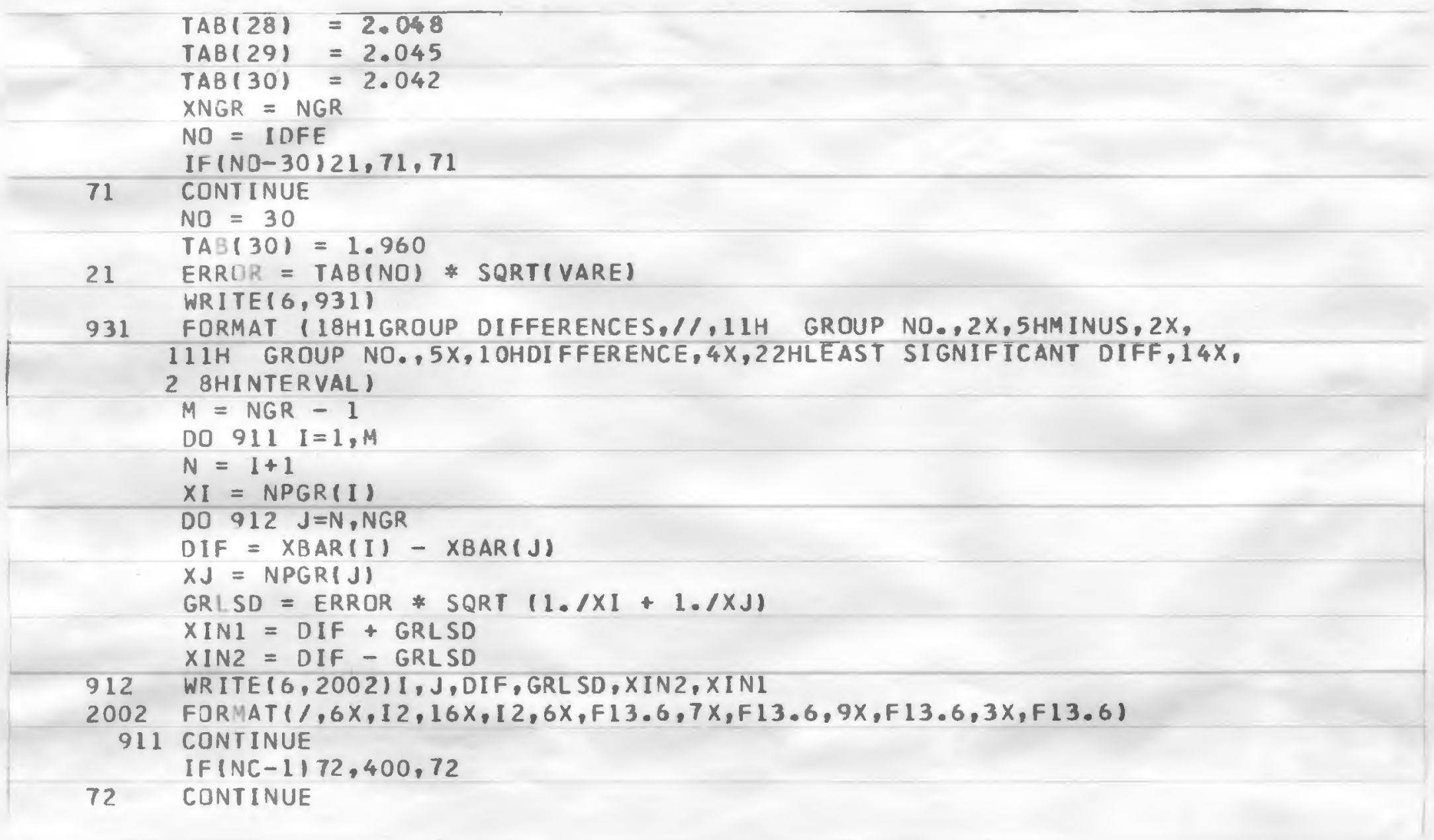




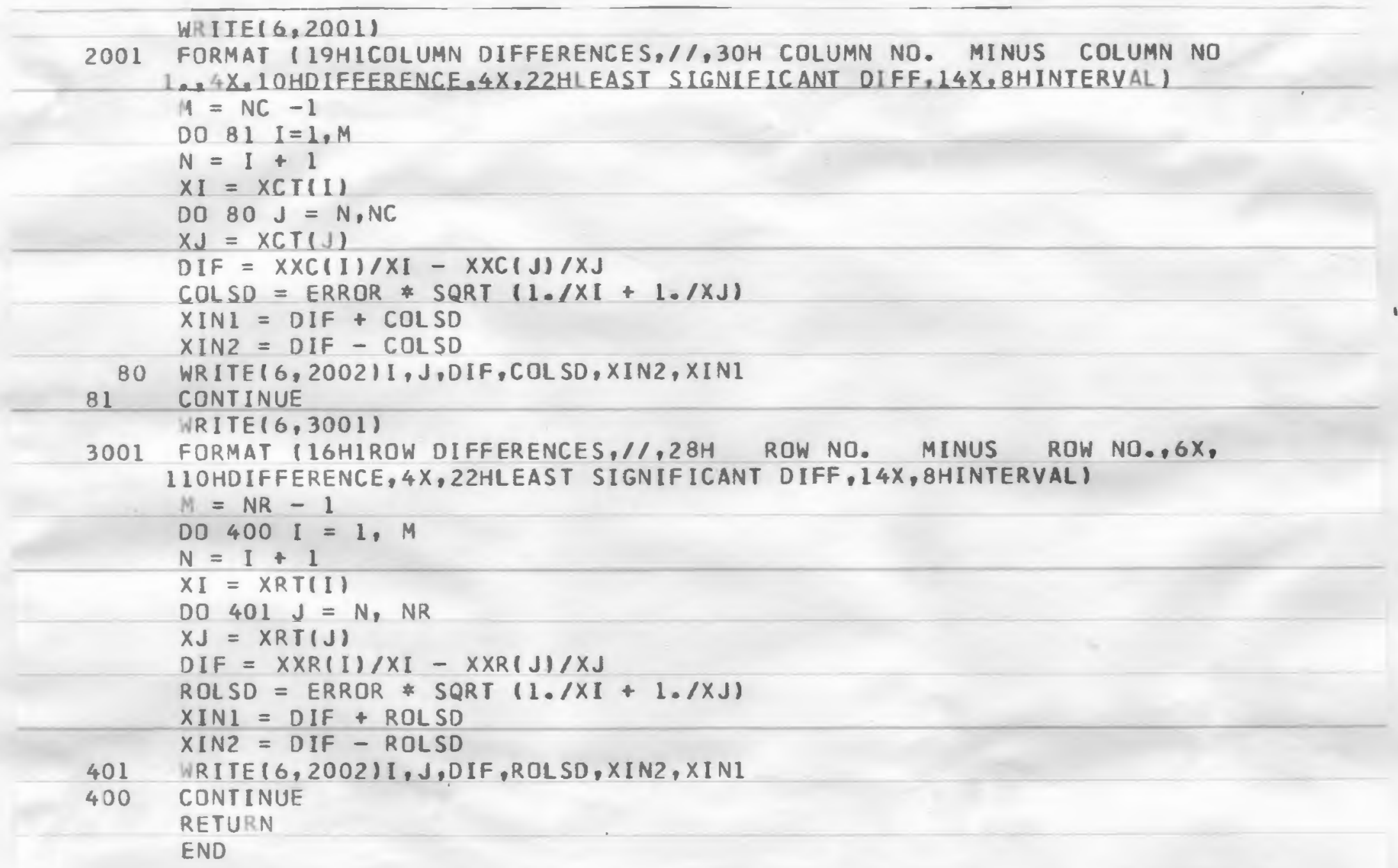




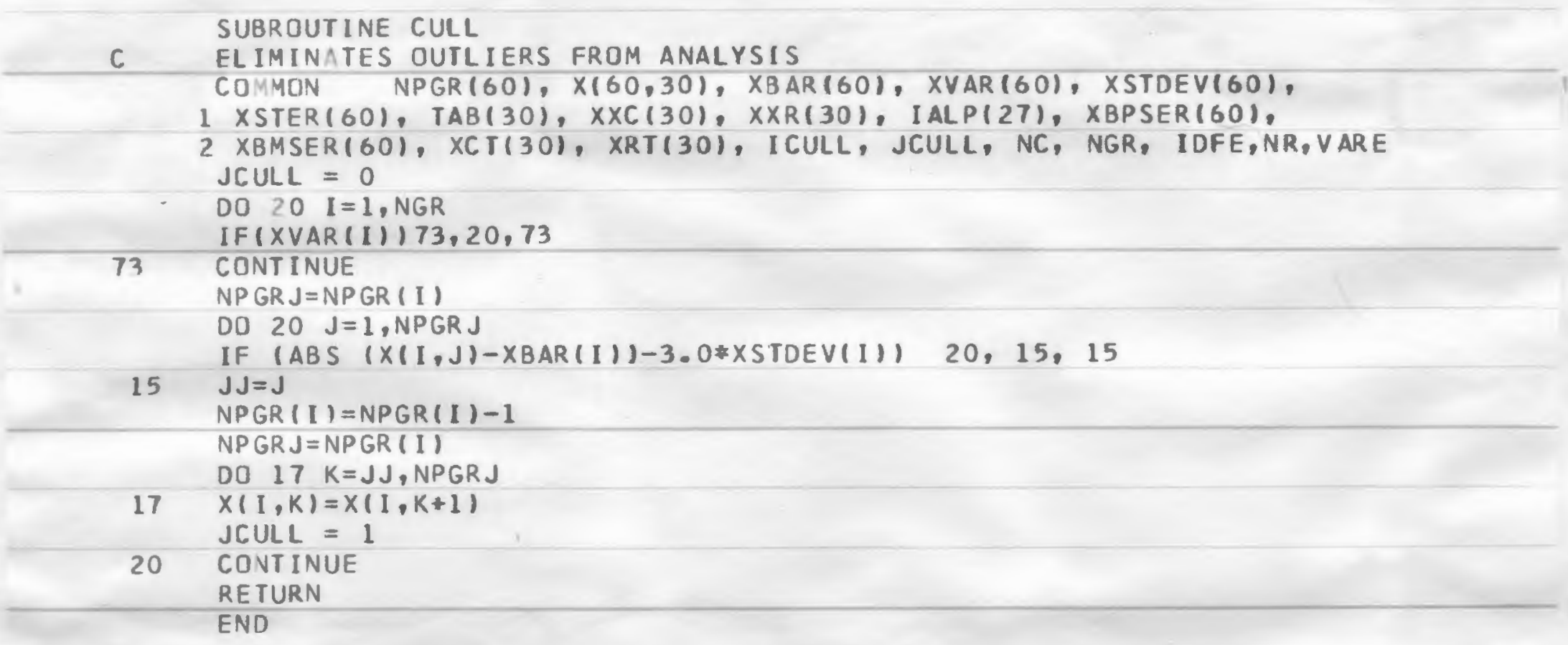

